\title{
The Law of Fair Use and the Illusion of Fair-Use Guidelines
}

\author{
KENNETH D. CREWS*
}

Several "official" and formal guidelines that attempt to define the scope of fair use for specific applications-notably for education, research, and library services-have emerged in the years since passage of the Copyright Act of 1976. Although some interested parties and some governmental agencies have welcomed these guidelines, none of them ever has had the force of law. This article analyzes the origins of guidelines, the various governmental documents and court rulings that reference the guidelines, and the substantive content of the guidelines themselves to demonstrate that in fact the guidelines bear little relationship, if any, to the law of fair use. The guidelines are negotiated resolutions of conflicts regarding fair use, and yet they are often presented as standards to which one must adhere in order to remain within the law. This article further analyzes the guidelines from a conceptual perspective and finds that the process of developing the guidelines gives them the appearance of a normative quality, while the portrayal of the guidelines as formal standards sanctioned by authoritative structures gives them the appearance of positive law. These qualities are merely illusory, and consequently the guidelines have had a seriously detrimental effect. They interfere with an actual understanding of the law and erode confidence in the law as created by Congress and the courts. Because pressure to develop additional guidelines appears inevitable, this article identifies deficiencies in the guidelines of the past and concludes with recommendations for improving the processes for, and the outcome of, future efforts to development new guidelines that interpret and apply the law of fair use.

\footnotetext{
${ }^{*}$ Kenneth D. Crews (B.A., Northwestem University; J.D., Washington University; Ph.D., University of California, Los Angeles) is a Professor in the Indiana University School of LawIndianapolis and the IU School of Library and Information Science. He is also Associate Dean of the Faculties for Copyright Management at Indiana University-Purdue University Indianapolis. Email address: kcrews@indiana.edu. Copyright 2001, Kenneth D. Crews.

This project began as a presentation delivered at Stanford University early in my involvement with the CONFU negotiations examined in the article. I labored on the project amidst other duties for too long, and it took on its final shape in connection with a presentation delivered at an interdisciplinary conference on intellectual property, held at The Ohio State University in February 2000. Accordingly, the study reflects transitions in my own views of the role and function of fair-use guidelines. I have deep thanks for the many colleagues and supporters whose comments at various stages steadily improved the article and encouraged the effort: Ann Bartow, Tom Bell, Dwayne Buttler, Robert Denicola, Laura Gasaway, Paul Goldstein, Sheldon Halpern, Henry Karlson, Cheryl Kern-Simirenko, Peter Knupfer, Mark Kombluh, Marshall Leaffer, Daniel Lee, Denise Nicholson, Ray Patterson, Vicki Reich, Florence Roisman, Carrie Russell, and Sandy Thatcher. Two graduate students at Indiana University provided essential assistance throughout: Noemi Rivera-Morales and Mary Jane Frisby. Two staff members, Rebecca Parman and Barbara Gushrowski, guided the manuscript through drafts and numerous changes. I give them my deepest thanks, but I remain responsible for all opinions and analyses. I extend additional gratitude to the Max Planck Institute for Foreign and International Patent, Copyright, and Competition Law, where I spent an inspiring sabbatical and completed the final revisions of this article in early 2001.
} 


\section{TABLE OF CONTENTS}

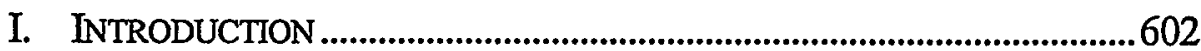

A. Background of Fair-Use Law and Guidelines..............................605

B. Perceptions of the Guidelines.....................................................612

II. FAIR-USE GUIDELINES FOR THE EDUCATION AND

RESEARCH ENVIRONMENT.................................................................614

A. Emergence of Fair-Use Guidelines (1935-1981) ........................614

1. Gentlemen's Agreement (1935) .............................................614

2. Classroom Guidelines (1976) ...............................................615

3. Music Guidelines (1976) .......................................................619

4. Off-Air Videotaping Guidelines (1981) ..................................620

5. Overview of the Early Guidelines............................................621

B. CONTU: The National Commission on New

Technological Uses of Copyrighted Works (1979) .......................622

1. Origins of the CONTU Guidelines .........................................622

2. Distinctive Traits of the CONTU Guidelines ..........................624

C. CONFU: The Conference on Fair Use (1994-1998) .................626

1. Background and Purposes of CONFU..................................626

2. Multimedia Guidelines ........................................................630

3. Distance-Learning Guidelines ..............................................632

4. Digital-Images Guidelines ....................................................634

D. Three Classes of Fair-Use Guidelines ........................................635

1. Guidelines and Legislative History........................................636

2. Guidelines and Congressional Commissions..........................636

3. Guidelines and Administrative Agencies...............................637

III. JUDICIAL DECISIONS AND FAIR-USE GUIDELINES.................................639

A. Courts and the Classroom Guidelines ........................................6.639

1. Association of American Publishers v.

New York University ..........................................................639

2. Basic Books, Inc. v. Kinko's Graphics Corp. ........................641

3. Princeton University Press v. Michigan Document Services, Inc......................................644

4. American Geophysical Union v. Texaco Inc. .........................648

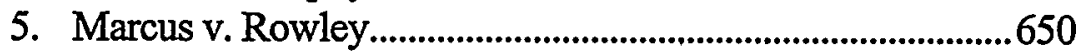

6. Bridge Publications, Inc. v. Vien ..............................................651 
B. Audiovisual Works: Encyclopaedia Britannica

Educational Corp. v. Crooks.

C. Interlibrary Loans: Williams \& Wilkins Co. v. United States... 656

D. Glimpses from the U.S. Supreme Court.

E. Synthesis of the Cases 662

IV. CONFLICTING PERCEPTIONS OF FAIR-USE GUIDELINES 663

A. Guidelines and the Law 664

1. Guidelines as a Measure of Fair Use 664

2. Guidelines as a Minimum Scope of Fair Use-the "Safe Harbor" 668

3. Guidelines as a Maximum Scope of Fair Use

4. Guidelines as Legislative History 672

5. Guidelines as an Instrument for Judicial Decisionmaking.

B. Guidelines and Their Parties

1. Guidelines as Agreement Not to Sue .674

2. Guidelines as Agreement among the Parties Regarding Fair Use. 675

C. Guidelines as a Substitution for Fair Use 677

1. The Proprietor's View: Tolerable Behavior 677

2. The User's View: Acting in Good Faith 679

3. The User's View: An Appearance of Propriety 682

D. Guidelines within the Academic Community. 684

V. A LEGAL THEORY OF FAIR-USE GUIDELINES 685

A. Relationship of Guidelines to Legal Theory 685

B. New Legal Theory for Fair-Use Guidelines .686

1. Positivist Concept of Guidelines. 686

2. Normative Concept of Guidelines 688

3. Combined Theory 689

VI. THE FUTURE OF FAIR-USE GUIDELINES: OBSERVATIONS AND RECOMMENDATIONS

A. Legal Status of Fair-Use Guidelines 691

B. Responding to the Guidelines. 694

C. Lessons for the Future Development of Guidelines 696

VII. CONCLUSION: PERCEPTIONS AND REALITIES 


\section{INTRODUCTION}

Early fair-use guidelines failed to reflect accurately the law or to embody workable standards, yet they have persisted as models for a new generation of interpretations applicable to the extraordinary demands of digital technology. ${ }^{1}$ The newest incarnations of guidelines perpetuate deficiencies of the past and create new hazards for copyright owners, users, and anyone else seeking to understand the law. ${ }^{2}$ Guidelines also have been the source of misconstructions of fair use in judicial rulings. This article will scrutinize the origins and application of the various guidelines from the past to reveal the limits and weaknesses of these standards of fair use. This analysis will also posit an innovative legal construct to underscore the deficiencies of formally recognized guidelines ${ }^{3}$ and

${ }^{1}$ Gregory K. Klingsporn, The Conference on Fair Use (CONFU) and the Future of Fair Use Guidelines, 23 CoLUM.-VLA J.L. \& ARTS 101, 101 (1999) ("Yet, despite this criticism, guidelines have remained a preferred method of applying the Copyright Act (or related regulation) to new technologies not envisioned by the drafters of the 1976 revisions.'); DanThu Thi Phan, Note, Will Fair Use Function on the Internet?, 98 COLUM. L. REV. 169, 198 (1998) (CONFU Guidelines are "modeled after the 1976 Fair Use Guidelines, also known as the Classroom Guidelines"). Future guidelines appear to be imminent, if not inevitable. See infra note 520. A central point of this article is that new guidelines can avoid the pitfalls and problems of the past, but only if the process of development is greatly revised. See infra Part VI of this article.

${ }^{2}$ Kym Carrier, Note, Right of Publicity: Cardtoons, L.C. v. Major League Baseball Players Association, 51 OKLA. L. REV. 159, 171-73 (1998) (demonstrating confusion over the concept of guidelines, this article uses the word "guideline" in reference to the factors in the fair-use statute itself).

3 The guidelines addressed in this article are significantly different from the many other "guidelines" that exist in other areas for the law. For example, judges apply "federal sentencing guidelines" in criminal cases and use guidelines to help determine the "best interests of the child" or the appropriate award of child support in family matters. See generally Marsha Garrison, Child Support Policy: Guidelines and Goals, 33 FAM. L.Q. 157 (1999); Debra H. Lehrmann, Who are We Protecting?: An Analysis of Law Regarding the Duties of Attorneys and Guardians Ad Litem, 63 TEX. B.J. 123, 126 (2000) ("These guidelines are not meant to contravene state law, but to fill in gaps where they exist."). The U.S. Department of Justice uses guidelines to examine whether corporate mergers may violate antitrust standards. The fair-use guidelines generally differ in at least two respects. First, except for the CONTU Guidelines, they are drafted by interested parties who have chosen to participate in the effort. Guidelines for other applications are usually drafted by appointed or invited experts, or they are developed and issued by commissions or agencies authorized to implement the law. See, e.g., BUREAU OF COMPETIIION, U.S. FEDERAL TRADE COMM'N, 1992 HORIZONTAL MERGER GUIDELINES [with April 8, 1997 Revisions to §4 Efficiencies] (1992), http:/www.ftc.gov/bc/docs/ horizmer.htm. Second, guidelines in other areas of the law are often specifically authorized by law, such as the sentencing guidelines. Federal statutes provide for the development of the sentencing guidelines, and a duly appointed commission creates them with judicial oversight. See Stephen Breyer, The Federal Sentencing Guidelines and the Key Compromises upon Which They Rest, 17 HOFSTRA L. REV. 1, 1-2 (1988) (noting that these guidelines have mandatory authority and were developed by a statutorily established commission). See also Stephen Breyer, Justice 
the pitfalls of accepting them as an adequate measure for understanding the law. Finally, this article closes with suggestions for better comprehending the nature of guidelines and for developing improved guidelines in the future.

For more than twenty years, various "official" guidelines have offered to define or at least explain the practical scope of fair-use law. ${ }^{4}$ The best-known of

Breyer: Federal Sentencing Guidelines Revisited, 14 CRIM. JUST. 28, 28-35 (1999). The guidelines in some other areas of the law are also different in that they often are indicators to decision makers about the law, but usually do not purport to have legal force or create the appearance of setting a definitive legal standard. See generally SAMUEL C. THOMPSON, JR., A PRACTTIONER'S GUIDE TO THE ECONOMICS OF THE ANTITRUST MERGER GUIDELINES (1997).

4 This article will focus especially on the following seven guidelines:

Agreement on Guidelines for Classroom Copying in Not-for-Profit Educational Institutions with Respect to Books and Periodicals, H.R. REP. No. 94-1476, at 68-70 (1976) [hereinafter Classroom Guidelines].

Guidelines for Educational Uses of Music, H.R. REP. NO. 94-1476, at 70-71 (1976) [hereinafter Music Guidelines].

Guidelines for Off-Air Recordings of Broadcast Programming for Educational Purposes, H.R. REP. No. 97-495, at 8-9 (1982) [hereinafter Off-Air Guidelines]. These guidelines first appeared in 127 Cong. Rec. 18, at 24,048-49 (1981).

CONTU Guidelines on Photocopying Under Interlibrary Loan Arrangements, in NATIONAL COMMISSION ON NEW TECHNOLOGICAL USES OF COPYRIGHTED WORKS, FINAL REPORT OF THE NATIONAL COMMISSION ON NEW TECHNOLOGICAL USES OF COPYRIGHTED WORKS, July 31, 1978 [hereinafter CONTU FNAL REPORT] 54-55 [hereinafter CONTU Guidelines].

Proposal for Educational Fair Use Guidelines for Digital Images, in INFORMATION INFRASTRUCTURE TASK FORCE, WORKING GROUP ON INTELLECTUAL PROPERTY RIGHTS, CONFERENCE ON FAIR USE: FINAL REPORT TO THE COMMISSIONER ON THE CONCLUSION OF THE CONFERENCE ON FAIR USE, November 1998 [hereinafter CONFU FNAL REPORT] 33-41 [hereinafter Digital-Images Guidelines].

Proposal for Educational Fair Use Guidelines for Distance Learning, in CONFU FINAL REPORT 43-48 [hereinafter Distance-Learning Guidelines].

Proposal for Fair Use Guidelines for Educational Multimedia, in CONFU FNAL REPORT 49-59 [hereinafter Multimedia Guidelines]. A slightly different version of the Multimedia Guidelines were the subject of a "nonlegislative report" issued by a congressional subcommittee in December 1996. See STAFF OF HOUSE SUBCOMM. ON COURTS AND INTELLECTUAL PROP. OF THE HOUSE COMM. ON THE JUDICIARY, 104TH CONG., FAIR USE GUIDELINES FOR EdUCATIONAL MULTIMEDIA (Comm. Print 1996) [hereinafter MUlTIMEDIA COMMITTEE PRINT]. For a discussion of the origins of this MULTIMEDIA COMMITTEE PRINT, see infra text accompanying notes 215-16. For a discussion of one critical way that the guidelines in the nonlegislative report differ from the "final" version published in the CONFU FNAL REPORT, see infra note 431.

The Digital-Images Guidelines, the Distance-Leaming Guidelines, and the Multimedia Guidelines are collectively referred to on occasion as the "CONFU Guidelines."

These guidelines share these common characteristics: they interpret either sections 107 or 108 of the U.S. Copyright Act, and they have been endorsed or supported or ratified by a governmental body. In those respects they are different from other possible guidelines that could also be the subject of study. For example, the report from the Conference on Fair Use also included a document entitled Statement on Use of Copyrighted Computer Programs (Software) 
such guidelines-addressing issues of photocopied handouts for classroom teaching 5 -has been available for scrutiny and application since passage of the first fair-use statute in 1976. Fundamentally, these and other guidelines respond to the fact that fair-use law is subject to many different and reasonable interpretations. In an attempt to address and relieve that uncertainty, interested parties have met periodically to develop guidelines detailing fair use, particularly for applications related to education. ${ }^{6}$ Stakeholders in the debate over the resulting guidelines have given them diverse descriptions and characterizations. The guidelines sometimes have been identified as "merely advisory" and at other times declared as the true meaning of fair-use law. In the context of fair-use law, however, each of those characterizations proves faulty, and most of them are not sustainable by any legal interpretation. This article will offer a legal analysis that can more accurately identify the legal significance of the guidelines, and that can provide a more reliable foundation for the emergence of inevitable guidelines in the future.

An enormous difficulty in coming to terms with the role of fair-use guidelines is that the literature of the law has largely neglected them and left them without a clear and meaningful conceptualization. ${ }^{7}$ That lack of clarity, nevertheless, has

in Libraries-Scenarios. See CONFU FINAL REPORT, at 61-65. That document, however, is principally an application of sections 108 through 109 of the Copyright Act. Further, the American Library Association and other organizations have issued interpretations of fair use that have been adopted by some educational institutions and other organizations, but not supported by governmental agencies. See, e.g., AMERICAN LIBRARY ASSOCIATION, MODEL POLICY CONCERNING COLLEGE AND UNIVERSTY PHOTOCOPYING FOR CLASSROOM, RESEARCH AND LIBRARY RESERVE USE(1982) [hereinafter ALA MODEL POLICY].

${ }^{5}$ See infra text accompanying notes 56-80.

${ }^{6}$ Klingspom, supra note 1, at 101 (stating, "copyright owners, copyright users, and legislators have attempted to increase the predictability of fair use through 'guidelines").

${ }^{7}$ No law review article has made a systematic study of the guidelines, although the guidelines have received moderate attention in the standard treatises on copyright and fair use. See, e.g., PAUL GOLDSTEN, 2 COPYRIGHT § 10.2.2(b) (2d ed. 1996 \& Supp. 1998); MELVILLE B. \& DAVID NIMMER, 4 NIMMER ON COPYRIGHT $\S 13.05$ (2000) [hereinafter NIMMER ON COPYright]; William F. PATRY, The FAIR USE PRIVILEgE IN COPYRIGHT LAW (1995) [hereinafter PATRY, FAIR USE] (covers only the earlier guidelines). On the other hand, the guidelines have been the subject of considerable discussion, but usually with little critical analysis, in numerous books that seek to apply fair use in the education or library setting. See, e.g., ARLENE BIELEFIELD \& LAWRENCE CHEESEMAN, LIBRARIES \& COPYRIGHT LAW (1993); JANIS H. BRUWELHEDE, THE COPYRIGHT PRIMER FOR LIBRARIANS AND EDUCATORS (1995); LAURA N. GASAWAY \& SARAH $\mathrm{K}$. WIANT, LibRARIES AND COPYRIGHT: A GUIDE TO COPYRIGHT LAW IN THE 1990S (1994); MARY BRANDT JENSEN, DOES YOUR PROJECT HAVE A COPYRIGHT PROBLEM? (1996). A few books, on the other hand, have offered some critical analysis. See, e.g., GROWING PAINS: ADAPTING COPYRIGHT FOR LIBRARIES, EDUCATION, AND SOCIETY (Laura N. Gasaway, ed., 1997) [hereinafter GASAWAY, GROWING PAINS]; ESTHER R. SINOFSKY, OFF-AIR VIDEOTAPING IN EDUCATION: COPYRIGHT ISSUES, DECISIONS, IMPLICATIONS 98-102 (1984). Various articles have offered different insights, and many of them are cited throughout this work. 
not stalled efforts to devise new guidelines. Indeed, recent efforts to devise new fair-use guidelines have been built explicitly on guidelines of the past as models-even though the merits of earlier guidelines never have been the subject of detailed legal scrutiny. ${ }^{8}$ This article will attempt the needed analysis.

This article will examine the manner in which fair-use guidelines have been characterized by interested parties and in court cases in order to test the validity of many of those portrayals and to discern the legal status and significance of the guidelines. The analysis is rooted in legal theory. This article will examine the several cases that have referenced any of the guidelines, ${ }^{9}$ and it will posit an understanding of the guidelines not only from the view of courts attempting to apply fair use, but also in the context of legal theories relating to positive law, normative law, and the significance of legislative history in the interpretation of statutes. ${ }^{10}$ This article will ultimately demonstrate that most of the guidelines that purport to interpret fair use in fact bear little credible relationship to the law, and that the guidelines of the past are a weak foundation for developing new interpretations for the future.

\section{A. Background of Fair-Use Law and Guidelines}

The fair-use doctrine of American copyright law has been derided as among the most hopelessly vague of legal standards, requiring complex and often subjective interpretation..$^{11}$ It has been scorned as the last, desperate defense from a scoundrel, who only claims fair use to avoid wanton liability. ${ }^{12}$ It has been attacked as a lure that draws into its trap fools who underestimate the wrath that the doctrine incurs among the circles of many copyright proprietors..$^{13}$ The

8 The final report from the Conference on Fair Use, see infra text accompanying notes $116-51$, includes several references to earlier guidelines as models for new guidelines. See, e.g., CONFU FNAL REPORT, supra note 4, at 6 ("Participants were encouraged to follow the example of previous successful efforts to develop voluntary fair use guidelines - the Classroom Guidelines in 1976, and the National Commission on New Technological Uses of Copyrighted Works ... which dealt with the issues raised by photocopiers and computers in 1978.").

${ }^{9}$ See infra Part III. Of particular importance in this analysis will be the following cases, which give considerable attention to the fair-use guidelines: Princeton University Press v. Mich. Document Servs., Inc., 99 F.3d 1381 (6th Cir. 1996) (en banc); Am. Geophysical Union v. Texaco Inc., 60 F.3d 913 (2d Cir. 1994), cert. dismissed, 516 U.S. 1005 (1995); Marcus v. Rowley, 695 F.2d 1171 (9th Cir. 1983); Basic Books, Inc. v. Kinko's Graphics Corp., 758 F. Supp. 1522 (S.D.N.Y. 1991).

10 See infra Part V.

11 Dellar v. Samuel Goldwyn, Inc., 104 F.2d 661 (2d Cir. 1939).

12 Jeremy Phillips, Nimmer on Copyright: David Nimmer Discusses Current US Copyright Law, and Possible Changes to It, MANAGING INTELL. ProP., Feb. 1995, at 17 (Nimmer calls fair use "the last resort of scoundrels.").

13 One article suggests that the application of fair use is inevitably amorphous: 
doctrine of fair use is also the cause of ample confusion among lawyers and laypersons alike, who often need to understand its nuances and live by its tenuous and fragile principles. A determination of whether or not some activity may or may not be fair use is actually akin to a prediction of how a judge might decide the same question, based on limited precedent and wide variations in possible interpretations. ${ }^{14}$

From another perspective, fair use is an essential element of effective communication and education, and it is a crucial bridge for the widespread sharing of ideas. ${ }^{15}$ Fair use allows an author to borrow a meaningful quotation from another source and to comment upon and share messages and missives exchanged on the Internet. ${ }^{16}$ Among the principal beneficiaries of fair use for the public interest have been the education and library communities. ${ }^{17}$ Indeed, fair

Many who have looked at the relationship between copyright protection and the fair use defense have concluded that finding a fair use is, at best, a matter of balancing hard-to-define equitable considerations, or at worst, a matter of luck. Additionally, for those of the orthodox school, obtaining a fair use exception in court is simply a matter of marshalling more emotionally appealing equities for fair use than the creator of the work can offer against fair use.

Michael G. Anderson \& Paul F. Brown, The Economics behind Copyright Fair Use: $A$ Principled and Predictable Body of Law, 24 LoY. U. CHI. L.J. 143, 144 (1993) (footnotes omitted).

14 Lisa M. Babiskin, Case Comment, Oh, Pretty Parody: Campbell v. Acuff-Rose Music, Inc., 8 HARV. J.L. \& TECH. 193, 223 (1994) ("In the absence of clear guidelines, fair use is essentially a rule of reason, the outcome depending on the facts and circumstances in each case.").

15 CONSORTIUM FOR EDUCATIONAL TECHNOLOGY IN UNIVERSITY SYSTEMS, FAIR USE OF COPYRIGHTED WORKS: A CRUCIAL ElEMENT IN EDUCATING AMERICA (1995) (This pamphlet was written in large part by the author of the present article; text of the work is available at http://www.cetus.org/fairindex.html (last visited April 4, 2001)). The purpose of fair use has been articulated in many ways. See, e.g., Elliott Epstein \& Andrew J. Zulieve, The Fair Use Doctrine: Commercial Misappropriation and Market Diversion, 13 ME. B.J. 142, 142 (1998) ("The 'Fair Use Doctrine' ameliorates the potentially suffocating effect on creative expression of the monopolistic rights conferred by the Copyright Act on authors of original works. In essence, the doctrine allows certain unauthorized uses of copyrighted work for criticism, comment, news reporting, teaching, scholarship and other 'transformative' purposes."); Phan, supra note 1, at 169. ("The copyright regime seeks to balance the public's desire for broad access to copyrighted works with the need to provide a pecuniary incentive for the copyright holder to disseminate her work.").

${ }^{16}$ Although, just making this statement is a highly presumptive act. The two common activities mentioned are not explicitly established as fair use in any statement of law from Congress or the courts, but they may be nearly universally acknowledged as fair use. That is: nearly universally. Open discussion at the CONFU meetings revealed that someone is always prepared to contest even the seemingly clearest example of fair use. See infra notes 141-46.

17 These communities are hardly the only groups benefiting enormously and importantly from fair use. Individuals who make copies at their local public library are exercising fair use. Lawyers who attach documents to court pleadings are engaged in fair use. Commercial publishers that excerpt sentences and other materials into new publications often depend on fair 
use is specifically applicable to teaching, scholarship, and research-the main objectives of educational institutions and of the users of libraries of all types-as they access information resources for their own learning and progress. ${ }^{18}$ In that regard, fair use is also consistent with the constitutional objectives of copyright in general: to promote the progress of science and the useful arts. ${ }^{19}$ The framers of the U.S. Constitution clearly intended that the law of copyright-including fair use-would be tailored to serve the advancement of knowledge. ${ }^{20}$

use. Indeed, the commercial publishing industry may be the greatest beneficiary of fair use, and it certainly has litigated its claim to fair use more often and with greater zeal than most parties. See, e.g., Harper \& Row Publishers, Inc. v. Nation Enters., 471 U.S. 539 (1985) (holding that quotations from an unpublished book manuscript used in a magazine are not fair use); Wright $v$. Wamer Books, Inc., 953 F.2d 731 (2d Cir. 1991) (holding that quotations from unpublished journal in a commercially published book are fair use); Salinger v. Random House, Inc., 811 F.2d 90 (2d Cir. 1987), cert. denied, 484 U.S. 890 (1987) (holding that quotations from unpublished letters for a commercially published biography are not fair use); Maxtone-Graham v. Burtchaell, 803 F.2d 1253 (2d Cir. 1986), cert. denied, 481 U.S. 1059 (1987) (book including extensive quotations successfully defended as fair use); Rubin v. Brooks/Cole Publ'g Co., 836 F. Supp. 909 (D. Mass. 1993) (reprinting a psychology test scale in a commercial textbook is fair use); Time Inc. v. Bernard Geis Assocs., 293 F. Supp. 130 (S.D.N.Y. 1968) (sketches from the Zapruder film included in a book as fair use). For a general study of fair use in the context of commercial applications, see Steven D. Smit, "Make a Copy for the File...": Copyright Infringement by Attorneys, 46 BAYLOR L. REV. 1 (1994).

1817 U.S.C. $\$ 107$ (1994) (describing in the preamble that fair use is "for purposes such as criticism, comment, news reporting, teaching (including multiple copies for classroom use), scholarship, or research").

19 The clause of the U.S. Constitution that empowers Congress to enact copyright law sets forth a policy for the law: "The Congress shall have Power... To promote the Progress of Science and useful Arts, by securing for limited Times to Authors and Inventors the exclusive Right to their respective Writings and Discoveries." U.S. CONST., art. I, $\S 8, \mathrm{cl}$. 8. Despite strenuous arguments to the contrary, a recent court ruling has held that the preamble language for this provision in fact has little substantive constraint on congressional authority to make copyright law. Eldred v. Reno, 239 F.3d 372, 378 (D.C. Cir. 2001). For a strong argument that the Copyright Clause is a limit on Congress, see Paul J. Heald \& Suzanna Sherry, Implied Limits on the Legislative Power: The Intellectual Property Clause as an Absolute Constraint on Congress, 2000 U. ILL. L. REV. 1119.

${ }^{20}$ In 1984 the Supreme Court made this statement about the social objective of limiting the rights of copyright owners: "The monopoly privileges that Congress may authorize are neither unlimited nor primarily designed to provide a special private benefit. Rather, the limited grant is a means by which an important public purpose may be achieved." Sony Corp. of Am. v. Universal City Studios, Inc., 464 U.S. 417, 429 (1984). In 1994, the Court made a more direct statement about the constitutional purposes that fair use serves: "From the infancy of copyright protection, some opportunity for fair use of copyrighted materials has been thought necessary to fulfill copyright's very purpose, ' $[t] 0$ promote the Progress of Science and useful Arts."' Campbell v. Acuff-Rose Music Inc., 510 U.S. 569, 575 (1994) (quoting U.S. CoNST., art. I, $\S 8, \mathrm{cl} .8)$. 
When Congress fully revised the Copyright Act in 1976, it added for the first time a statutory provision on fair use.21 After many years of hearings and recommendations, ${ }^{22}$ Congress ultimately chose to give fair use little definition. ${ }^{23}$ The fair-use statute specifies that fair use applies to teaching, research, scholarship, and other educational needs, but the determination of fair use in any particular case depends on an application of four factors. The text of section 107 of the Copyright Act articulates those principles:

Notwithstanding the provisions of sections 106 and 106A, the fair use of a copyrighted work, including such use by reproduction in copies or phonorecords or by any other means specified by that section, for purposes such as criticism, comment, news reporting, teaching (including multiple copies for classroom use), scholarship, or research, is not an infringement of copyright. In determining whether the use made of a work in any particular case is a fair use the factors to be considered shall include-

(1) the purpose and character of the use, including whether such use is of a commercial nature or is for nomprofit educational purposes;

(2) the nature of the copyrighted work;

(3) the amount and substantiality of the portion used in relation to the copyrighted work as a whole; and

(4) the effect of the use upon the potential market for or value of the copyrighted work.

The fact that a work is unpublished shall not itself bar a finding of fair use if such finding is made upon consideration of all the above factors. ${ }^{24}$

Because case law in 1976 had not begun to address common educational needs, and because the four factors in the statute could be interpreted differently to produce divergent outcomes, educators and other parties were resolved to identify with some greater certainty the meaning and scope of fair use. ${ }^{25}$

${ }^{21}$ Copyright Act of 1976, Pub. L. 94-553, 90 Stat. 2541 (1976) (codified as amended at 17U.S.C.)

22 The effort in Congress that led to passage of the Copyright Act of 1976 began in 1955 when Congress authorized the U.S. Copyright Office to conduct studies of various copyright issues. The Copyright Office delivered those studies in 1960 and 1961, which began the process of legislation in earnest. Thirty-four studies were reprinted in SENATE COMM. ON THE JUDICIARY, 86TH CONG., COPYRIGHT LAW REVISION STUDY (Comm. Print 1960). The thirtyfifth study was published in 1963. For the congressional appropriation that is generally credited with initiating these studies, see Legislative Appropriation Act for Fiscal Year 1956, 69 Stat. 499,517 (1950).

${ }^{23}$ H.R. REP. No. 94-1476, at 66 (1976) ("The statement of the fair use doctrine in section 107 offers some guidance to users in determining when the principles of the doctrine apply. However, the endless variety of situations and combinations of circumstances that can arise in particular cases precludes the formulation of exact rules in the statute.").

24 17 U.S.C. $\$ 107$ (1994).

${ }^{25}$ H.R. REP. No. 94-1476, at 66-67 (1976). 
Congress was not prepared to include further details in the law, but it urged the stakeholders to negotiate their concerns and to reach agreement about the meaning of the law. ${ }^{26}$ The outcome of that effort was the series of early guidelines. ${ }^{27}$ Negotiations in the mid-1970s gave rise to the first set of guidelines on the issue of photocopying for classroom handouts. ${ }^{28}$ Soon came guidelines on making copies of musical works for education, ${ }^{29}$ and later emerged guidelines on sending copies of journal articles for interlibrary loans ${ }^{30}$ and recording television broadcasts off-air for classroom use. ${ }^{31}$ Once these guidelines were developed, Congress usually gave them a gesture of acceptance, but little substantive scrutiny. A few court decisions since then have relied on them, although with mixed impressions. ${ }^{32}$ Despite the legal ambiguity of guidelines, the impetus to devise guidelines for fair use has accelerated in recent years as interested parties struggle with new applications of copyright law..$^{33}$

Three proposals for new fair-use guidelines were included in a December 1998 report of the Conference on Fair Use, also known as CONFU. ${ }^{34}$ Issued by

${ }^{26}$ H.R. REP. NO. 94-1476, at 66-67 (1976); H.R. REP. No. 89-2237, at 62 (1966). Professor Jessica Litman has been less patient with the pressures from Congress. She has written that Congress "encouraged, cajoled, bullied, and threatened the parties through continuing negotiations." Jessica D. Litman, Copyright, Compromise, and Legislative History, 72 CORNELl L. REV. 857, 871 (1987). See also Off-Air Taping for Educational Use: Hearings Before the House Subcomm. on Courts, Civil Liberties, and the Administration of Justice, 96th Cong. 3-4 (1979). With respect to negotiating guidelines for off-air videotaping, Thomas E. Mooney, Associate Counsel to the Subcommittee, made this statement: "This is an area which I am afraid we are going to have to revisit and revisit, and then revisit again, until hopefully a solution of sorts emerges." Id. A recent Register of Copyrights made this sweeping statement: "It is our perception... that in the past the Congress in general and this subcommittee in particular have expressed their preference and desire for the interested parties in the various copyright issues voluntarily to resolve them among themselves." Copyright Office/Copyright Royalty Tribunal: Hearings Before the House Subcomm. on Courts, Civil Liberties, and the Administration of Justice, 98th Cong. 5 (1983) (remarks of David L. Ladd). This statement suggests that, despite the many purposes and characterizations attributed to the guidelines, see infra Part IV, one additional underlying purpose of the guidelines is to help Congress avoid the need to address the issue in a level of detail demanded by some interested parties.

27 Those guidelines are listed at supra note 4.

28 Classroom Guidelines, supra note 4.

${ }^{29}$ Music Guidelines, supra note 4.

30 CONTU FINAL REPORT, supra note 4.

31 Off-Air Guidelines, supra note 4.

32 See, e.g., Basic Books, Inc. v. Kinko's Graphics Corp., 758 F. Supp. 1522, 1535-37 (S.D.N.Y. 1991) (referring to the Classroom Guidelines). See infra Part III of this article.

33 Of particular importance in recent years has been the work of the Conference on Fair Use to devise a new generation of guidelines. See infra text accompanying notes 116-96.

${ }^{34}$ CONFU FNAL REPORT, supra note 4, at 31-59. See also INFORMATION INFRASTRUCTURE TASK FORCE, WORKING GROUP ON INTELLECTUAL PROPERTY RIGHTS, CONFERENCE ON FAIR USE: REPORT TO THE COMMISSIONER ON THE CONCLUSION OF THE FIRST 
the U.S. Patent and Trademark Office, the report included proposals for guidelines on the issues of multimedia development, digitizing of visual images, and distance learning. ${ }^{35}$ Those proposed guidelines have been the subject of conflicting and sometimes hostile debate. Many of the major education and library associations opposed them, ${ }^{36}$ and many publishers and other proprietor groups have given the guidelines their endorsement. ${ }^{37}$ Despite the good intentions of CONFU organizers, the planned effort to reach consensus seems in some respects further away today than it did when CONFU first convened in 1994.38

PHASE OF THE CONFERENCE ON FAIR USE, (1997) [hereinafter CONFU INTERIM REPORT]. This report is similar in many respects to the report issued nearly two years later, and includes the text of the same three proposed guidelines.

35 CONFU FNAL REPORT, supra note 4, at 33-59.

36 For example, among the groups opposing some or all of the CONFU Guidelines were: American Association of State Colleges and Universities (AASCU), American Coumcil on Education (ACE), American Historical Society (AHS), American Library Association (ALA), Association of American Universities (AAU), Association of Research Libraries (ARL), Medical Library Association (MLA), National Association of State Universities and LandGrant Colleges, and the American Association of Law Libraries (AALL). See NotIFICATIONS RECEIVED FROM ORGANZATIONS ON THE PROPOSALS FOR FAIR USE GUIDELINES, at http://www.uspto.gov/web/offices/dcom/olia/confu/notif.htm (last visited April 4, 2001).

37 Support for the various CONFU Guidelines was diffused. Numerous organizations noted on the public record their support for the Multimedia Guidelines, but most of those groups did not take a public position on the other guidelines. Among those supporters, particularly of the Multimedia Guidelines, were: Association of American Publishers (AAP), Association of American University Presses, Inc. (AAUP), Broadcast Music, Inc. (BMI), Consortium of College and University Media Centers (CCUMC), American Society of Composers, Authors and Publishers (ASCAP), Motion Picture Association of America (MPAA), Software Publishers Association (SPA), Association of American Colleges and Universities (AAC\&U), American Association of Community Colleges (AACC). See NOTIFICATIONS RECEIVED FROM ORGANIZATIONS ON THE PROPOSAIS FOR FAIR USE GUIDELINES, at http://www.uspto.gov/web/offices/dcom/olia/confu/notifhtm (last visited April $4,2001)$. The list of endorsers of the Multimedia Guidelines also appears in the CONFU FINAL REPORT, supra note 4, at 56-57.

38 CONFU convened at the behest of the U.S. Information Infrastructure Task Force, which issued the "Green Paper" report in July 1994 calling on the diverse interest groups to negotiate an understanding of fair use for educational needs in lieu of any proposal for legislative action on fair use. INFORMATION INFRASTRUCTURE TASK FORCE, WORKING GROUP ON INTELlECTUAL PROPERTY RIGHTS, INTELLECTUAL PROPERTY AND THE NATIONAL INFORMATION INFRASTRUCTURE: A PRELIMINARY DRAFT OF THE REPORT OF THE WORKING GROUP ON INTELLECTUAL PROPERTY RIGHTS (1994) [hereinafter GREEN PAPER]. According to the GREEN PAPER: "Therefore, the Working Group will sponsor a conference to bring together copyright owner and user interests to develop guidelines for fair uses of copyrighted works by and in public libraries and schools." Id. at 134. In September 1995, the IITF issued a final "White Paper" that emphasized the hopes that CONFU would resolve the conflicts over fair use relatively quickly: "[T]t appears reasonable to anticipate that drafts now in preparation may be formalized as guidelines before the end of 1995." INFORMATION INFRASTRUCTURE TASK FORCE, WORKING GROUP ON INTELLECTUAL PROPERTY RIGHTS, INTELLECTUAL PROPERTY AND 
This article will suggest that the fractured outcome of CONFU may be traced to the lack of objective legal analysis of fair-use law and guidelines. ${ }^{39}$

This article reflects on almost twenty-five years of experience with existing guidelines, with the hope that experience will offer insights about their significance-or lack of significance. A better understanding of the record of existing guidelines should also help address the fundamental questions about future guidelines: Do fair-use guidelines offer an appropriate standard for copyright owners and users who must make frequent fair-use determinations? What are the qualities or attributes of guidelines that make them successful or unsuccessful in the context of fair-use applications? To facilitate the creation of more effective guidelines and to better scrutinize guidelines that are offered to universities and others for implementation, copyright owners and users alike need a fresh look at, and a critical framework for, understanding guidelines.

Despite the weak platform from which guidelines are promoted, they continue to have appeal in the marketplace simply because the unsettled nature of fair use leaves many individuals uncomfortable with applying the law. ${ }^{40}$ The law of fair use regularly leaves lawyers, judges, and the public in turmoil and debate over its meaning and application. The U.S. Copyright Act now codifies broad

THE NATIONAL INFORMATION INFRASTRUCTURE: THE REPORT OF THE WORKING GROUP ON INTELLECTUAL PROPERTY RIGHTS 83 (1995) [hereinafter WHITE PAPER]. The first meeting of CONFU was held in September 1994, more than two years before issuance of the three proposed guidelines in the CONFU INTERIM REPORT, supra note 34. For the announcement of the first CONFU meeting, see Conference on "Fair Use" and the National Information Infrastructure (NII), 59 Fed. Reg. 46,823 (Sept. 12, 1994). The WHITE PAPER from 1995 added this motivation for the CONFU participants: "Should the participants in the Conference on Fair Use fail to agree on appropriate guidelines, the Working Group may conclude that the importance of such guidelines may necessitate regulatory or legislative action in that area." WHITE PAPER, supra, at 84.

${ }^{39}$ Readers should know that I participated in most of the meetings of CONFU on behalf of Indiana University and the Indiana Partnership for Statewide Education. The experience proved to be of utmost importance in reshaping my understanding of fair use and the role and nature of guidelines. See Kenneth D. Crews, Electronic Reserves and Fair Use: The Outer Limits of CONFU, 50 J. AM. SOC'Y FOR INFO. SCI. 1342 (1999); Kenneth D. Crews, What Qualifies as "Fair Use"?, CHRON. HIGHER ED., May 17, 1996, at B1. Because the guidelines for electronic reserves, on which this author focused considerable effort, were never formalized and accepted by the CONFU participants, they are not included among the policies analyzed in this article. For an overview of electronic reserves and associated copyright issues, see Steven J. Melamut, Pursuing Fair Use, Law Libraries, and Electronic Reserves, 92 L. LIB. J. 157 (2000).

40 During hearings that eventually led to enactment of the Copyright Revision Act of 1976 , an attorney representing a coalition of educators stated: "What education needs is a statute which will enable teachers easily to know when they can use copyrighted materials. Proposed section 6 [on fair use] does not give this certainty, but means that a teacher in preparing every single lesson must either consult a lawyer or act at her risk." STAFF OF THE HOUSE COMM. ON THE JUDICIARY, 89TH CONG., COPYRIGHT LAW REVISION PART 5: 1964 REVISION BILL WITH DISCUSSIONS AND COMMENTS 97 (Comm. Print 1965) (Statement of Harry N. Rosenfield). 
principles underlying fair use, but ultimately offers few details for understanding its meaning in specific applications. ${ }^{41}$ Yet each day thousands of individuals depend on fair use for the furtherance of education, research, and public serviceexactly the pursuits that the law was intended to support. But they may often make their decisions based on speculation and erroneous information. Many individuals also make decisions at their peril; articulations of fair use by educators, librarians, researchers, and students are the object of hostile criticism and even threats of litigation from groups representing copyright owners. The law affords ample opportunity for reasonable people to differ widely about fair use, but the law also gives copyright owners the ability to threaten lawsuits when differing views are otherwise unresolved.

\section{B. Perceptions of the Guidelines}

In a lineage of diverse sources-from informal essays to institutional policies-fair-use guidelines have been given a wide range of characterizations and appellations. These descriptions have come from many diverse perspectives and have continued from the inception of the first guidelines in 1976 through today. These characterizations also reflect the complex relationship that the guidelines have with the law, with the parties who created them, and with the marketplace where difficult fair-use decisions occur. Those decisions need to be made by individuals who may benefit from fair use or who may be adversely affected by the exercise of fair use. The decisions also signal whether a copyright owner may want to consider bringing an infringement action. The decisions further indicate a great deal about the mutual relationships among copyright owners and users and the terms on which they may find themselves agreeing to co-exist in a complex environment of competing pressures and often opposing ideals. Guidelines are specifically intended to shape those decisions. How one understands and characterizes the guidelines, therefore, will consequently shape the fair-use decision based upon them.

Part IV of this article will examine the validity of the many ways that the guidelines have been perceived and characterized since their inception in 1976. In broad terms, the guidelines have been described in terms of their relationship to the law of fair use itself. If the guidelines bear no relationship to fair use law, they are futile or perhaps even a fraud. ${ }^{42}$ In their strongest endorsement, they are described as an accurate statement of fair use law. The "Uniform Preamble" to the CONFU guidelines, for example, states: "The purpose of these guidelines is to

41 17 U.S.C. $\$ 107$ (1994).

42 See L. RaY PatTerson \& Stanley W. Lndberg, The Nature of Copyright: A LAW OF USERS' RIGHTS, 8-9 (1991). 
provide guidance on the application of fair use principles ...."43 The connection to the law cannot be overlooked.

More often, the guidelines are portrayed as a "minimum" measure of fair use, or are a "safe harbor" from infringement.44 The earliest guidelines, from 1976, include a declaration that they "state the minimum and not the maximum standards of educational fair use under section 107."45 In that regard, the guidelines apparently offer a "safe harbor" from infringement. ${ }^{46}$ On the other hand, unless the guidelines are some statement of security from litigation, then they are not even a minimum standard. ${ }^{47}$ Whether minimum, maximum, or definitive, the various guidelines clearly claim to be some version of fair-use law. 48

If the guidelines are not about the law, they may instead define the private relationship between parties to the guidelines themselves. The earliest of the guidelines, the Classroom Guidelines, were formally entitled an "agreement," and parties to the CONFU guidelines are described as "endorsers."49 This language suggests assent to terms, whether contractual or not. The guidelines perhaps have been most significant in shaping institutional policy. In that regard, they may well be binding on the parties that agree to accept them as standards of behavior for members of an educational institution that uses the guidelines as formal policy. ${ }^{50}$ These possible perceptions of the guidelines only hint at the confusion that surrounds them.

43 CONFU FNAL REPORT, supra note 4, at 31.

${ }^{44}$ See infra Part IV.A.2.

45 Classtoom Guidelines, supra note 4, at 68.

46 See infra Part IV.A.2.

47 This particular clause in the preamble has been a point of serious contention among CONFU participants. Some negotiators have understood it as a generous expression of openness to possible fair use beyond the defined limits of the guidelines; as the CONFU preamble does make explicit that something beyond the limits of the guidelines may still be fair use. See CONFU FINAL REPORT, supra note 4, at 31-32. Other negotiators have seen the language as an anchor on the flexibility of fair use, constantly pulling one back to the gravitational center of the stated limits in the guidelines.

48 The concept of guidelines as minimum standards is discussed infra Part IV.A.2. The concept of guidelines as maximum standards is discussed infra Part IV.A.3.

49 Classroom Guidelines, supra note 4; see also infra note 431.

$50 \mathrm{An}$ analysis of fair-use policies at leading research universities revealed that approximately eighty percent of the institutions incorporated some of the early guidelines into their formal policy statements on fair use. KENNETH D. CREWS, COPYRIGHT, FAIR USE, AND THE CHALIENGE FOR UNIVERSITIES 73 (1993) (The Classtoom Guidelines "are the foundation for the policies at approximately eighty percent of the universities that address either classroom or research copying.'). See also id. at 98 (Of the fifty-four policies addressing interlibrary loans "all but eight are rooted in the CONTU Guidelines."). 


\section{FAIR-USE GUIDELINES FOR THE EDUCATION AND RESEARCH ENVIRONMENT}

\section{A. Emergence of Fair-Use Guidelines (1935-1981)}

Despite the essential relationship between fair use, educational institutions, and libraries, remarkably little legislation or litigation has dealt with even the most common examples of possible fair use, ranging from simple photocopying to customary uses of the Internet. ${ }^{51}$ Given the relative void of true legal guidance, stakeholders in the enterprise of teaching, learning, and librarianship have met periodically during the last few decades to negotiate "guidelines" that attempt to define an understanding of fair use as it may apply to frequently occurring situations. ${ }^{52}$ Part II of this article will survey the origins and content of the guidelines. Critical analysis of the relationship between the guidelines and the law of fair use will be set forth in Parts IV and V.

\section{Gentlemen's Agreement (1935)}

The earliest example of such a fair-use guideline was the so-called "Gentlemen's Agreement" of 1935 that identified instances of reproduction of short copyrighted works that would be allowed under the law at that time. ${ }^{53}$ The relatively simple standard was a response to the introduction of photographic and other photo-duplication equipment in libraries. ${ }^{54}$ As technologies evolved in the following decades, particularly with the growth of high-speed photocopying, the

51 The few cases that offer some insight for education or library applications do not involve such nonprofit entities that are generally favored under fair use. See, e.g., Basic Books, Inc. v. Kinko's Graphics Corp., 758 F. Supp. 1522, 1522 (S.D.N.Y. 1991) (photocopying by a for-profit copyshop).

52 For a list of the guidelines examined in this article, see supra note 4.

53 The Gentlemen's Agreement and the Problem of Copyright, 2 J. DOCUMENTARY REPROD. 29, 31-33 (1939). See also Alan Latman, Fair Use of Copyrighted Works, reprinted in STAFF OF SENATE COMM. ON THE JUDICIARY, 86TH CONG., STUDY No. 14, § 11-12, COPYRIGHT LAW REVISION (Comm. Print 1960) (suggesting that the Gentlemen's Agreement revealed an intention by the publishing industry to regulate private activity and not to concede common uses).

${ }^{54}$ Previously, the controversy over fair use had focused on the lawfulness of making manual transcriptions of articles and other research materials found in a library. See generally R.R. Bowker, The National Library as the Central Factor of Library Development in the Nation, 37 LIBR. J. 3, 3-6 (1912). As recently as 1973, counsel to Williams \& Wilkins Co., a journal publishing company, suggested that a student who transcribes content of the joumal for research or study would be making a "technical infringement." Copyright Law Revision: Hearings Before the Subcomm. on Patents, Trademarks, and Copyrights of the Senate Comm. on the Judiciary, 93rd Cong., 152-53 (1973) (remarks of Arthur Greenbaum). 
debate over fair use shifted from isolated copies to multiple copies that more likely held the risk of replacing purchases of copyrighted works. ${ }^{55}$

\section{Classroom Guidelines (1976)}

The best known of all fair-use guidelines emerged in 1976, not coincidentally in conjunction with the passage of the newly revised Copyright Act. ${ }^{56}$ For the first time, the law embodied fair use in statutory terms, and not merely as a judicial doctrine. 57 To many copyright proprietors-particularly publishers-the newly codified fair use was a challenge or even a threat. ${ }^{58}$ Although the new statute was fundamentally unspecific and susceptible to broad interpretations, it nevertheless made unequivocal that fair use would exist and could be raised in a wide range of cases. 59 The new statute also stated explicitly that fair use would generally apply to educational uses, including multiple copies of protected works for teaching purposes. ${ }^{60}$ The new law, as enacted in 1976, was astonishingly simple in its reliance on four factors: the purpose of the use; the nature of the work; the amount of the work used; and the effect of the use on the value of, or the market for, the original work. ${ }^{61}$

For many educators, however, the new statute was uncomfortably vague, demanding analyses of four factors on which even the most seasoned copyright lawyers could not reach agreement. 62 The legal interpretations and the possible legal liabilities were daunting to the teachers, librarians, and administrators who

55 Other proposals for fair-use standards emerged in the intervening years, but with little acceptance. For example, the American Library Association issued a "Reproduction of Materials Code" in 1941. See Borge Varmer, Photoduplication of Copyrighted Material by Libraries, reprinted in STAFF OF SENATE COMM. ON THE JUDICIARY, 86TH CONG., STUDY NO. 15, COPYRIGHT LAW REVISION 52-53 (Comm. Print 1960).

56 For the Copyright Act of 1976 as originally passed by Congress on October 19, see Pub. L. No. 94-553, 90 Stat. 2541 (1976).

${ }^{57}$ Fair use in American copyright law originated in judicial rulings. Scholars generally regard the doctrine as having originated in Folsom v. Marsh, 9 F. Cas. 342 (C.C.D. Mass. 1841) (No. 4,901).

58 See, e.g., Copyright Law Revision: Hearings Before the Subcomm. on Patents, Trademarks of the Senate Comm. on the Judiciary, 90th Cong. $974-76$ (1967) (remarks of William M. Passano, president of the Williams \& Wilkins Co.).

59 See H.R. REP. No. 94-1476, at 65-67 (1976).

6017 U.S.C. $\$ 107$ (1976).

$61 \mathrm{Id}$.

62 Early in the process leading to passage of the Copyright Act of 1976, educators urged Congress to enact a fair-use law with specific provisions for permitted copying. Author and publisher groups opposed specifics in the law, as did the U.S. Copyright Office. See Copyright Law Revision: Hearings Before the Subcomm. on Patents, Trademarks, and Copyrights of the House Comm. on the Judiciary, Supplementary Report of the Register of Copyrights, 89th Cong. 27-28 (1965). 
found themselves needing to make responsible decisions that, they hoped, were in conformity with the law. ${ }^{63}$ Even if they were inclined to take on the task, the nuances of fair use appeared demanding and time-consuming. Each new situation, each new member of the faculty or staff, and each new report about copyright developments could engender a raft of new questions, absorbing the scarce time of educators. Most educators have little time or propensity for such complexities, and copyright responsibilities should not be a burden on, or distraction from, educational duties. ${ }^{64}$ Moreover, difficult decisions about fair use are a steady reminder that erroneous decisions might expose instructors to legal liabilities.

Yet, the reality was that copyright law set limits on the use of protected works. In particular, the Copyright Act of 1976 granted to copyright owners exclusive rights of reproduction and distribution of their works, along with various other rights. 65 Without a fair-use right, all copying of materials for the simple pursuit of classroom handouts would be prohibited. ${ }^{66}$ The new fair-use statute, however, allowed copies for teaching, but only within the limits of the four factors. Educators were once again thrust into the unwelcome position of needing to understand and apply the uncertain law.

From this apparent intrusion by copyright, and from the new uncertainty that fair use seemed to represent, came a yearning for more specific guidance about

63 Educators expressed concerns about the challenge of fair-use decisions well before passage of the Copyright Act of 1976. In 1967, a representative of educator groups explained: "Fair-use gives teachers and scholars no assurance of when copyrighted materials may be copied, nor how much, nor under what specific circumstances." Copyright Law Revision: Hearings Before the Subcomm. on Patents, Trademarks and Copyrights of the Senate Comm. on the Judiciary, 89th Cong. 122 (1965) (remarks of Harry N. Rosenfield). See also H.R. REP. No. 90-83, at 30 (1967) (Educators "argued further that the doctrine of fair use alone is insufficient to provide the certainty that teachers and other nonprofit educational users of copyrighted material need for their own protection."). If the educator is incorrect about a fairuse decision, and the activity is an infringement, the possible liabilities for copyright infringement include: injunctions, impoundments, actual damages, statutory damages, attomey fees and court costs, and even criminal penalties. 17 U.S.C. $\S \S 502-06$ (1994). For further discussion of statutory damages, see infra text accompanying notes 441-48.

${ }^{64}$ The burdens on individuals are the "transaction costs" of decisions about fair use, and the guidelines have an intended function of reducing those costs. See Kenneth D. Salomon \& Michael J. Pierce, Commentary, Copyright Law and the Information Superhighway, 96 WEST'S EDUC. L. REP. 315, 325 (1995).

65 Copyright owners in general have the exclusive rights to reproduce the works, to distribute copies to the public, to make derivative works, and to make public displays and performances. 17 U.S.C. $\$ 106$ (1994 \& Supp. IV 1998). With respect to works of visual art, the author has certain "moral rights," notably the right of attribution and integrity. 17 U.S.C. $\S$ 106A (1994). A "work of visual art" is defined generally as paintings, sculpture, and some photographs made in limited copies. 17 U.S.C. § 101 (1994 \& Supp. IV 1998).

66 Of course, theoretically, some other right under some other name could allow such copying, but this discussion will adhere to the current law and its offerings. 
the law's meaning. ${ }^{67}$ Consequently, representatives of educators, authors, and publishers met during the years prior to passage of the 1976 Act in order to negotiate an understanding of the new law as applied specifically to multiple photocopies of materials for classroom use. ${ }^{68}$ The product of those meetings was the "Agreement on Guidelines for Classroom Copying in Not-for-Profit Educational Institutions," also known as the "Classroom Guidelines." 69

The Classroom Guidelines are built on the premise that some photocopying of materials for distribution to students is within fair use, but with limits. These guidelines allow single copies of short items, such as an article or book chapter, to be made by a teacher for research or class preparation. Multiple copies for distribution, however, are subject to the rigorous limits of "brevity," "spontaneity" and "cumulative effect." Copies must include "a notice of copyright." "Brevity" is a precise limit on the number of words that an instructor may copy from each work; the user must literally count the words in the original article, count the words in the excerpt for copying, and stay within specified limits.71 "Spontaneity" means that the copying is at the instructor's "instance and inspiration" and needs to be so close in time to classroom use "that

${ }^{67}$ See Ann Bartow, Educational Fair Use in Copyright: Reclaiming the Right to Photocopy Freely, 60 U. PITT. L. REv. 149, 159-63 (1998) (tracing origins of the Classroom Guidelines); Anderson \& Brown, supra note 13, at 144-45.

${ }^{68}$ Much of the effort to complete the Classroom Guidelines came in the final months leading to passage of the Copyright Act of 1976, once Congress had made clear that it would not enact a statute that detailed the law applicable to educational needs. Still, the parties did meet early in the process to reach agreement, but without success until the brink of passage of the act by Congress. See Copyright Law Revision: Hearings Before the Subcomm. on Patents, Trademarks, and Copyrights of the Senate Comm. on the Judiciary, 90th Cong. 618 (1967) (remarks of Erwin C. Surrency).

${ }^{69}$ Classroom Guidelines, supra note 4.

${ }^{70}$ The Classroom Guidelines do not explicitly state whether the notice must be the formal copyright notice as appears on the original work, or whether it may be some general statement about copyright and its applicability to the work. The debate over the form of notice was part of the struggle over similar language in section 108(a) of the Copyright Act. 17 U.S.C. $\$ 108(a)$ (1994 \& Supp. IV 1998). Congress recently clarified the matter by amending the statute to provide that copies made under section 108 must include the formal notice as it appears on the original. If no notice is on the original, the copy must include the general statement about copyright. Digital Millennium Copyright Act, Pub. L. No. 105-304, § 404, 112 Stat. 2860, 2889-90 (1998) (amending section 108(a) of the Copyright Act). Perhaps the logic of that construct could be extended to the Classtoom Guidelines.

${ }^{71}$ For example, if an article is less than 2,500 words, the instructor may copy the entire article. If it is more than 2,500 words, the instructor may copy only an excerpt of a length equal to the lesser of either 1,000 words or ten percent of the work-although the excerpt may in any event be at least 500 words in length, and the instructor may go a little over the limit to reach the end of a "prose paragraph." Despite these rigors, one commentator has described the Classtoom Guidelines as allowing "fairly liberal photocopying for purposes of research and scholarship." Diane Leenheer Zimmerman, Copyright in Cyberspace: Don't Throw out the Public Interest with the Bath Water, 1994 ANN. SURV. AM. L. 403, 411 n.18. 
it would be unreasonable to expect a timely reply to a request for permission."772 "Cumulative effect" generally puts a cap on the number of works that may be copied from an individual source. ${ }^{73}$ For example, during a single instructional term, the teacher may copy only one article from a single author, or three articles from a single collection or periodical, and no course shall include more than nine instances of multiple copying during the term.

In addition to these three standards, the Classroom Guidelines also offer "prohibitions."74 Even if the copying is scrupulously within the three conditions of brevity, spontaneity, and cumulative effect, some activities are still forbidden under the guidelines. For example, students may not be charged for the material beyond the actual copying cost; the copying cannot substitute for a purchase of books and other publications; a teacher may not copy the same material in more than one term; and the copying "shall not be used to create or to replace or substitute for anthologies, compilations or collective works."75 The Classroom Guidelines not only blatantly diverge from the four factors in the fair-use statute and replace them with three different mandates, but also add blanket prohibitions that cannot be overcome by any balancing of factors or equities. ${ }^{76}$ The guidelines unquestionably displace the law with a standard that is a departure from the statute in many respects.

The most common attraction of the guidelines is their promise of relative certainty about fair use. ${ }^{77}$ Yet even an objective and generally supportive discussion of the guidelines will often yield more questions about not only their legal significance but also their factual applicability. Nimmer on Copyright gives the Classroom Guidelines tremendous deference in the interpretation of fair use, ${ }^{78}$ but when attempting to explain their content, the treatise proceeds to question the validity and consistency of the word limits and puzzles over the concept of "special works,"

72 Classroom Guidelines, supra note 4, at 69. See also Steven K. Barton, Comment and Note, Felony Copyright Infringement in Schools, 1994 B.Y.U. EDUC. \& L.J. 143, 154.

73 Classroom Guidelines, supra note 4, at 69.

$74 \mathrm{Id}$.

75 Id.

76 Classroom Guidelines, supra note 4, at 69-70. For an additional summary of criticisms of the guidelines, see Carol M. Silberberg, Presenving Educational Fair Use in the Twenty-First Century, 74 S. CAL. L. REV. 617, 637-39 (2001).

${ }^{77}$ Classroom Guidelines, supra note 4, at 68. See also Babiskin, supra note 14, at 223; Mary R. Barry, Note, Multiple Photocopying by Educators and the Fair Use Doctrine: The Court's Role in Reducing Transactions Costs, 1994 U. ILL. L. REV. 387, 395.

78 See infra text accompanying notes 383-86.

79 Classroom Guidelines, supra note 4, at 69 (defining "special works" as "[c]ertain works in poetry, prose or in 'poetic prose' which often combine language with illustrations and which are intended sometimes for children and at other times for a more general audience fall short of 2,500 words in their entirety"). 
the treatment. ${ }^{80}$ The guidelines may well offer more certainty, but they still raise their own questions and pose their own problems for application.

\section{Music Guidelines (1976)}

The apparent need for guidelines was not limited to simple classroom copying, even upon the passage of the 1976 Act. A second set of guidelines, addressing the copying of music for instructional purposes, ${ }^{81}$ was in the same House Report that included the Classroom Guidelines. ${ }^{82}$ These "Music Guidelines" focus on a few common situations that arise in the teaching of music. They outline when teachers may copy sheet music for classroom performance, or record and duplicate student performances of copyrighted music. ${ }^{83}$

The Music Guidelines lack the highly detailed standards of the Classroom Guidelines. For example, they allow "emergency copying" of music for an "imminent performance," provided that the school or instructor purchases replacement copies "in due course." 84 An instructor may copy excerpts of music for "academic purposes other than performance." 85 The excerpt is not measured strictly by quantity, but must be less than a "performable unit" and not more than ten percent of the entire work. ${ }^{86}$ Instructors may also record performances by students and may make a single copy of an existing sound recording 87 for constructing aural exercises or examinations. ${ }^{88}$ These guidelines also include

804 NMMER ON COPYRIGHT, supra note 7, at $\$ 13.05$ [E][3][c], n. 534.

81 Music Guidelines, supra note 4.

82 Classtoom Guidelines, supra note 4. See H.R. REP. No. 94-1476, at 68-71 (1976).

83 Id. at $70-71$.

84 Id. at 71 .

$85 \mathrm{Id}$.

86 Id.

87 Since the drafting of the Music Guidelines, Congress has enacted the Audio Home Recording Act, Pub. L. No. 102-563, 106 Stat. 4237 (1992) (codified as amended at 17 U.S.C. $\S \S 1001-10$ (1994 \& Supp. IV 1998)), which generally bars copyright infringement actions against individuals who use certain audio recording equipment to make copies of sound recordings of musical works. In return, the music industry receives revenue from a "tax" imposed on the sale of recording devices and materials. Consequently, the making of copies of sound recordings may be perfectly lawful, within the narrow conditions of a single copy for classroom use. While the Music Guidelines may have been a reasonable interpretation of fair use in 1976, they may not reflect the broader rights of this particular use that current law allows. See generally, A\&M Records v. Napster, Inc., 239 F.3d 1004, 1024-25 (9th Cir. 2001) (holding that the AHRA exemption from liability does not apply to music files downloaded onto computer drives).

88 In a most revealing twist, the Music Guidelines add parenthetically this statement to the provision allowing copies of sound recordings: "This pertains only to the copyright of the music itself and not to any copyright which may exist in the sound recording." Supra note 4, at 71. One can only surmise that negotiations leading to the guidelines included participation from 
"prohibitions" similar to the ones found in the Classroom Guidelines. ${ }^{89}$ Like the Classroom Guidelines, these guidelines make no pretence of relating the detailed standard of fair use to the four factors in the law. While they may not be as meticulous as the Classroom Guidelines in their measurement of fair use, they still stray far from the law's flexibility.

\section{Off-Air Videotaping Guidelines (1981)}

In addition to the classroom handouts and music copies, one more set of guidelines was in preparation in 1976, but the House Report duly noted that it was not yet ready for final approval and publication. ${ }^{90}$ Not until 1981 did the parties negotiating these guidelines reach a conclusion"1 and issue the "Guidelines for

representatives of the owners of compositions, and not participation by representatives of the recording artists. For a study of the creation of these guidelines, with confirmation of the perhaps incomplete representation in the drafting, see Barbara L. Bell, The Controversy Over Establishing Fair Use Guidelines for Off-Air Videotaping for Educational Uses: A Case Study of Attempts to Formulate Policy 170-77 (1980) (unpublished Ph.D. dissertation, Indiana University) (on file with the Indiana University Education Library).

${ }^{89}$ One of the prohibitions in the Music Guidelines provides that all copies must include "the copyright notice which appears on the printed copy." Supra note 4, at 71. Unlike the Classroom Guidelines, this standard clarifies that the notice must be the formal notice, and not a general statement of copyright. See supra note 70.

90 H.R. REP. No. 94-1476, at 71-72 (1976).

91 After passage of the Copyright Act of 1976, negotiators continued to meet, notably in a four-day session during July 1977 , to draft guidelines. That effort broke down and needed to be reinvigorated in congressional hearings nearly two years later. See Off-Air Taping for Educational Use: Hearings Before the House Subcomm. on Courts, Civil Liberties, and the Administration of Justice, 96th Cong. 2 (1979) (remarks of Rep. Robert Kastenmeier). Apparently causing much of the delay was the reluctance of the motion picture industry, notably the Motion Picture Association of America, to endorse the guidelines that would allow some off-air taping of its works. During the protracted negotiations, congressional hearings attempted to advance the effort, and an officer of the MPAA made this broad statement: "And quite frankly, it is the view of the motion picture companies that the taping of entire copyrighted works off the air is an infringement and not a fair use." Id. at 32 (remarks of James Bouras). The MPAA never did endorse the Off-Air Guidelines. Not long after issuance of the guidelines in 1981, prominent members of the MPAA filed a lawsuit against Sony Corporation, asserting that its manufacture and sale of home videorecording devices was contributory infringement. Universal Studios, Inc. v. Sony Corp. of Am., 480 F. Supp. 429, 432 (C.D. Cal. 1979). The U.S. Supreme Court eventually ruled in that case that home recording of off-air broadcasts was fair use. Sony Corp. of Am. v. Universal City Studios, Inc., 464 U.S. 417, 455 (1984). At the time, the MPAA may well have acted in its own appropriate self-interest by not endorsing guidelines that could weaken, however slightly, its infringement claim that it was soon to assert. In retrospect, the decision to file that lawsuit has been heavily criticized as short-sighted, with analysts pointing to the rapid growth of the motion picture industry and revenues following the widespread consumer acceptance of videocassette recorders. See generally, JAMES LARDNER, FAST FORWARD: HOLLYWOOD, THE JAPANESE, AND THE ONSLAUGHT OF THE VCR 284-85 (1987). 
Off-Air Recording of Broadcast Programming for Educational Purposes."92 Better known as the "Off-Air Guidelines," this standard would, in general, allow a teacher to record, off-the-air, a television broadcast for later use or "performance" in classroom teaching. The instructor could use the tape in the classroom on only one occasion ${ }^{93}$ and then only during the first ten school days during the forty-five calendar days following the date of the transmission and copying. ${ }^{94}$ Any repeat or later use would require permission. ${ }^{95}$

The Off-Air Guidelines differ in some important respects from the other guidelines, but they also share some common traits. Like the others, these guidelines are not built explicitly on the four statutory factors. Elements of the guidelines may well be relevant to satisfaction of the factors, but the guidelines do little if anything to make the connection to the language of the law. Unlike many other standards, the Off-Air Guidelines are not as unrelentingly precise in their measure of fair use. The guidelines are specific about the span of days during which the recording may be used, but the guidelines do not place exacting limits on the quantity of the broadcast that may be either recorded or used. Indeed, the guidelines allow the teacher to record and use the entire televised work. In that regard, the Off-Air Guidelines may be easier to apply and more palatable than some of the other standards, but those differences do not necessarily tell whether they are a more accurate statement of fair-use law.

\section{Overview of the Early Guidelines}

The Classroom Guidelines, the Music Guidelines, and the Off-Air Guidelines have much in common with one another. They were developed through voluntary negotiations among diverse stakeholders, often representing copyright owners, publishers, educators, librarians, and others. ${ }^{96}$ Each set of guidelines was

92 Off-Air Guidelines, supra note 4, at 8-9

$93 \mathrm{Id}$. Repeat use is allowed only once and "only when instructional reinforcement is necessary."

${ }^{94} \mathrm{Id}$.

$95 \mathrm{Id}$.

96 For the Classroom Guidelines, members of the negotiating team included: Ad Hoc Committee of Educational Institutions and Organizations on Copyright Law Revision; the Authors League of America, Inc.; and the Association of American Publishers, Inc. For the Music Guidelines, members included: Music Publishers' Association of the United States, Inc.; National Music Publishers' Association, Inc.; Music Teachers National Association; Music Educators National Conference; National Association of Schools of Music; and the Ad Hoc Committee on Copyright Law Revision. For the Off-Air Guidelines, members included the Agency for Instructional Television; Association of Media Producers; Motion Picture Association of America; American Library Association; National Education Association; Association for Educational Communications and Technology; Authors League of America; Screen Actors Guild; Joint Council on Educational Communications; Directors Guild of America; Association of American Publishers; National Association of Broadcasters; Public 
delivered to Congress, and the committee reports included favorable observations and lent important credibility to the guidelines as reasonable, if not positive, developments consistent with the law that Congress had actually made. ${ }^{97}$ Those comments appear in congressional reports and other official publications, lending the appearance of "official" approval to the guidelines. 98 The legal community will undoubtedly recognize that publication in a report does not make the guidelines "law." Yet the larger public is not prepared to grasp or appreciate the distinction, often leading to a conclusion that the guidelines are accepted by Congress and therefore must be accepted by the American public in its quest to understand fair use. Moreover, none of the guidelines exhibits any relationship to the statutory definition of fair use; none is built on the four factors that Congress and the courts have laid down as the actual measure of lawful activity. 99

\section{B. CONTU: The National Commission on New Technological Uses of Copyrighted Works (1979)}

\section{Origins of the CONTU Guidelines}

A fourth set of early guidelines emerged under considerably different conditions. When Congress enacted the Copyright Act of 1976, Congress also recognized that the law was flexible to meet new technologies, but had not specifically addressed the looming demands of computers and large-scale photocopying. ${ }^{100}$ To begin a close examination of the new law, Congress established the National Commission on New Technological Uses of Copyrighted Works (CONTU) and authorized it to make recommendations for revising and implementing the new law. ${ }^{101}$

Broadcasting Service; American Council on Education; National School Boards Association; Writers Guild of America, East; American Federation of Television and Radio Artists; ABC; and CBS.

97 See, e.g., H.R. REP. No. 94-1476, at 72 (1976):

Teachers will know that copying within the guidelines is fair use. Thus, the guidelines serve the purpose of fulfilling the need for greater certainty and protection for teachers. The Committee expresses the hope that if there are areas where standards other than these guidelines may be appropriate, the parties will continue their efforts to provide additional specific guidelines in the same spirit of good will.

98 See, e.g., H.R. REP. No. 94-1476, at 72 (1976) ("The Committee believes the guidelines are a reasonable interpretation of minimum standards of fair use.").

${ }^{99}$ See infra text accompanying notes $367-77$.

100 See 120 CONG. REC. 30, 516 (1974) (remarks of Sen. McClellan, recognizing that there would be new "copyright issues ... arising from the development of new technology.").

101 CONTU FNAL REPORT, supra note 4, at 3-5. See Pub. L. No. $93-573$ (1974). 
One provision of the Copyright Act that CONTU confronted was section $108(\mathrm{~g})(2)$, which provided for qualified libraries ${ }^{102}$ to engage in the making and distribution of photocopied materials in furtherance of "interlibrary arrangements," or loans. The new law allowed libraries to make copies of some works to meet the research and study needs of individual users. ${ }^{103}$ Those copies may also be sent to users at other libraries who request the copies. 104 When making those copies for distribution as interlibrary loans, however, the law establishes further conditions. In general, section 108 prohibits any "systematic" copying-which could be multiple copies sent through interlibrary loans-but the law nevertheless allows interlibrary arrangements:

The rights of reproduction and distribution under this section extend to the isolated and unrelated reproduction or distribution of a single copy or phonorecord of the same material on separate occasions, but do not extend to cases where the library or archives, or its employee-

... engages in the systematic reproduction or distribution of single or multiple copies or phonorecords of material...: Provided, That nothing in this clause prevents a library or archives from participating in interlibrary arrangements that do not have, as their purpose or effect, that the library or archives receiving such copies or phonorecords for distribution does so in such aggregate quantities as to substitute for a subscription to or purchase of such work. ${ }^{105}$

In its final report, issued in 1979, CONTU offered guidelines for interpreting that statutory standard, at least with respect to copies of recent periodical articles, the mainstay of many interlibrary-loan operations. Under the CONTU Guidelines, libraries are allowed to receive from another library, during a calendar year, up to five copies of articles from the most recent five years of issues of a single journal. ${ }^{106}$ Under that standard, receipt of a sixth article in a year would imply a sufficient demand for that periodical such that the receiving library may be relying on interlibrary arrangements that substitute for a subscription to the work. ${ }^{107}$ Many libraries use the guidelines to evaluate the need to purchase a subscription, or upon reaching the sixth copy begin to seek permission for making

102 The statute specifies, in particular, that for a library to have the benefits under section 108 , it must be "open to the public" or at least not limited exclusively to users who are affiliated with the library or its parent institution. 17 U.S.C. $\$ 108(a)(2)$ (1994). Most public libraries and academic,libraries will likely meet this requirement. Private or corporate libraries may not.

103 For example, the library may make copies of chapters of books and articles under some conditions, and may even copy an entire book or other lengthy work under more rigorous conditions. 17 U.S.C. $\$ \S 108(d)-(e)$ (1994).

104 Id.

10517 U.S.C. $\$ 108(\mathrm{~g})$ (1994).

106 CONTU FINAL REPORT, supra note 4, at 55-56.

107 Id. at 56. 
additional copies or decide to pay a fee to a service such as the Copyright Clearance Center. ${ }^{108}$

\section{Distinctive Traits of the CONTU Guidelines}

The CONTU Guidelines are not truly "fair-use" guidelines; they are not an interpretation of section 107 of the Copyright Act. Nevertheless, they are closely aligned with the other guidelines, and section 108 is also deployed in libraries and educational institutions alongside section 107 , often to facilitate similar services in fulfillment of education and research needs. Yet these guidelines are in other respects fundamentally different from the three other standards. First, while the CONTU Guidelines are the outgrowth of a congressional commission, the fairuse guidelines are the product of negotiations among interested parties. This difference is critical in many respects.

Voluntary negotiations have intrinsic limits. The parties who are most likely to attend are the ones perceiving the most immediate concern about the issueoften the parties with the greatest financial stake. The parties may also be the ones with the financial wherewithal to attend negotiating sessions at all. Voluntary negotiations also mean that the outcome has the potential of being skewed by an imbalance of representation among the diverse perspectives, or even the absence of some points of view. ${ }^{109}$ By contrast, the appointment of commissioners to a limited number of positions holds the prospect that the major views on copyright matters will be represented and balanced. Appointment to a federal commission may also imbue each individual with a greater sense of public service, perhaps with an objective of serving the greater good, and not the short-term demands of the company or organization that may be paying the travel costs and daily wages — or hourly billings — of each negotiator.

108 GASAWAY \& WIANT, supra note 7, at 54-55 (outlining several alternatives for libraries upon reaching the limits of the guidelines). A study in 1983 determined that more than forty percent of academic libraries that fulfilled interlibrary-loan requests had refused to fulfill user's requests for copyright reasons, and more than thirty percent of those libraries refused to fill some requests received from other libraries for copyright reasons. COPYRIGHT OFFICE, REPORT OF THE REGISTER OF COPYRIGHTS: LIBRARY REPRODUCTION OF COPYRIGHTED WORKS (17 U.S.C. $\S 108$ ) (1983), app. I, at 1-6. For more information about the Copyright Clearance Center, see: http:/www.copyright.com (last visited April 4, 2001).

${ }^{109}$ For example, during the CONFU negotiations, see infra text accompanying notes 116-51, educators complained of being "outgunned." See Robert L. Jacobson, Furor over "Fair Use:" Educators Seem Outgunned in Negotiations with Copyright Owners, 42 CHRON. HIGHER EDUC., May 10, 1996, at A25, and subsequent letters to the editor, 42 CKRON. HIGHER EDuC., June 14, 1996, at B4. The court in the Kinko's decision was not inclined to evaluate retrospectively the process for formulating the Classroom Guidelines once they had congressional support. Basic Books, Inc. v. Kinko's Graphics Corp., 758 F. Supp. 1522, 1535 n.10 (S.D.N.Y. 1991). See infra Part III.A.2. 
A second distinction of the CONTU Guidelines is their substantive measure of legal rights of use. Whatever the ambiguities of the law, these guidelines set a standard that is relatively easy for a library to implement and that allows the library to deliver a meaningful quantity of material to the patron who requested it.110 The Classroom Guidelines would have educators count words before copying for some uses; the Music Guidelines refer to copies of ten percent of some works. By contrast, the CONTU Guidelines are based on a useful unit of intellectual content-a journal article-without the need to count words or define some other disruptive sub-unit in order to claim a rightful exercise of fair use. 111

The CONTU Guidelines differ from other guidelines in a third respect: their foundation in a judicial decision. ${ }^{112}$ This article will look closely at court cases which have referred to the various fair-use guidelines following their development and issuance. ${ }^{113}$ Those cases, of course, arose after issuance of the guidelines. Negotiators of those guidelines did not have the benefit of insight from direct court rulings. By contrast, the CONTU Guidelines emerged from practices that were in fact devised and implemented at a major research library and that were later scrutinized and judged in the course of litigation against that library. ${ }^{114}$ The effort to create the CONTU Guidelines was directly aided by the views of judges who ruled on the critical issues and scrutinized a library's practices; the CONTU commissioners had the benefit of knowing what other judges would likely allow to pass muster under a fair-use analysis. ${ }^{115}$

110 Several early studies indicated that the CONTU Guidelines were not necessarily a serious limit on library services. See, e.g. Dale R. Middleton, Predicting the Impact of Copyright Specifications on Interlibrary Borrowing, 65 BULL. MED. LIBR. ASSOC. 449 (1977); John Steuben, Interlibrary Loan of Photocopies of Articles under the New Copyright Law, 70 SPEC. LIBR. 227 (1979); Johanna E. Tallman, One Year's Experience with CONTU Guidelines for Interlibrary Loan Photocopies, 5 J. ACAD. LIBR. 71 (1979).

111 Similarly, the Off-Air Guidelines do allow copies of entire broadcasts. See Off-Air Guidelines, supra note 4, at 8 ("A broadcast program may be recorded off-air.... 'Broadcast programs' are television programs transmitted by television stations for reception by the general public without charges.").

112 Williams \& Wilkins Co. v. United States, 487 F.2d 1345 (Ct. Cl. 1973).

113 See infra Part III. III.C.

${ }^{114}$ For a discussion of that litigation that led to the CONTU Guidelines, see infra Part

115 Although the CONTU Guidelines closely parallel the copying that was sanctioned in the Williams \& Wilkins decision, the report from CONTU that offered the guidelines surprisingly does not analyze that case. See CONTU FNAL REPORT, supra note 4, at 52-75 (examining the issues surrounding library photocopying). The report does mention the case only in a brief footnote with respect to growing concerns about copyright in the late 1960 s. CONTU FINAL REPORT, supra note 4, at 5 n.14. 


\section{CONFU: The Conference on Fair Use (1994-1998)}

\section{Background and Purposes of CONFU}

The Conference on Fair Use (CONFU) was an informal gathering of interested parties, convening at the behest and encouragement of government officials." 16 The genesis of CONFU lies in a draft report, known as the "Green Paper," of the Working Group on Intellectual Property Rights of the Information Infrastructure Task Force (ITTF). ${ }^{117}$ That task force was an assembly of federal officials, business executives, and representatives of various nongovernmental organizations. ${ }^{118}$ Each member presumably brought some combination of expertise and representation of diverse interests in the outcome of the ITF. In its Green Paper, issued in July 1994, the Working Group outlined and summarized a wide range of copyright and related issues affecting the expansion of digital commerce and communication. ${ }^{119}$ One of those issues of major concern was fair use. ${ }^{120}$

The Green Paper summarized the law of fair use and addressed problems raised with the application of existing law to the needs and circumstances of digital technology. ${ }^{121}$ New technologies were creating a new environment where copyright protected materials may be easily used in the name of fair use but may be extensively reproduced and disseminated beyond the limits of the law.122 Rather than propose legislation, as the report did with respect to other issues, ${ }^{123}$ the Green Paper instead made this proposition: "Therefore, the Working Group will sponsor a conference to bring together copyright owner and user interests to develop guidelines for fair uses of copyrighted works by and in public libraries and schools." 124

116 GREEN PAPER, supra note 38, at 134.

117 Id.

118 See Exec. Order No. 12,864, 3 C.F.R. 634 (1993). IITF's chair is the Secretary of Commerce; at the time it was the late Ronald H. Brown. See IITF's website, http://www.iitf.nist.gov (last visited April 4, 2001).

119 Green Paper, supra note 38, at 120-39.

$120 \mathrm{Id}$. at 133.

121 Id. at $45-53$.

122 Id. at 134.

123 For example, the GREEN PAPER included proposals for legislation on issues such as transmission and the expansion of the distribution right, the meaning of publication, and the applicability of the first-sale doctrine. See id. at 120-33.

124 Id. at 134. 
CONFU held its first meeting on September 21, 1994, in Washington, D.C., under the direction of an official from the U.S. Patent and Trademark Office. ${ }^{125}$ Meetings occurred on a frequent basis-often monthly-with approximately forty individuals regularly participating in most meetings. Most of those participants were from the publishing industries, educational organizations, and library associations. ${ }^{126}$ Many other individuals attended less regularly. In September, 1995 the Working Group issued its final report, known as the "White Paper."'127 It provided this summary of developments after a year of CONFU meetings:

To date, no formal guidelines have been the subject of agreement, but it appears reasonable to anticipate that drafts now in preparation may be formalized as guidelines before the end of $1995 . .$.

Should the participants in the Conference on Fair Use fail to agree on appropriate guidelines, the Working Group may conclude that the importance of such guidelines may necessitate regulatory or legislative action in that area. ${ }^{128}$

Not until September 1997 did the work of CONFU progress to the stage of having draft guidelines ready for broad, public distribution. ${ }^{129}$ An interim report included "proposals" for guidelines on three topics: multimedia development, the use of digital images, and the transmission of works through distance learning. 130 A year later, in December 1998, the final report from CONFU included the same three sets of interpretive guidelines. ${ }^{131}$ During that year, however, the public was invited to review the proposals and to indicate support or opposition to them. ${ }^{132}$

That process revealed sharp divisions among the interested parties. ${ }^{133}$ Many of the commercial publishers, for example, generally supported the guidelines. Many of the organizations representing educational institutions and libraries

125 CONFU FINAL REPORT, supra note 4, at 6 . The individual who originally led the meetings was Christopher A. Meyer. He left the PTO in July 1995 and was replaced by Peter Fowler. Id. at 6 . Their public duties were generally confined to convening the meetings, distributing announcements, and preparing progress reports. Outside public view, these individuals mediated sensitive discussions and balanced competing pressures, particularly as the final report took shape. As the drafter of the final report, Mr. Fowler was especially influential in determining the outcome of CONFU.

126 See Conference on Fair Use Participants, CONFU FINAL REPORT, supra note 4, at 19.

127 WHTTE PAPER, supra note 38.

128 Id. at 83-84.

129 CONFU INTERIM REPORT, supra note 34.

130 Id. at 35-64.

131 Id. at 33-59.

132 Id. at 14.

${ }^{133}$ Id. at 18 ("Some participants opposed the process, as well as the results, while others strongly supported both. Others strongly supported the process, but determined that they could not, or would not, support the results."). 
opposed the guidelines. 134 None of the guidelines had anything approaching unanimous support. ${ }^{135}$ In fact, the Digital-Images Guidelines received nearly no support. By contrast, the earlier guidelines from the 1970s and 1980s had support from nearly all the parties who expressed an interest; ${ }^{136}$ few parties openly opposed them when they were issued. ${ }^{137}$ The CONFU guidelines, however, stirred sharp opposition from many prominent groups. Still, they gained support from many other groups and even from governmental agencies.

CONFU was an effort to bring diverse groups together to reach a mutual resolution of major issues of fair use. ${ }^{138}$ The outcome of the effort, by contrast, revealed deep division in the participants' understanding of fair use. ${ }^{139}$ Anticipating that division and the resistance of some parties to adopt the guidelines, the CONFU report labeled them as "proposals" for guidelines. 140 Apparently they would move beyond a "proposal" status only with some unspecified future action-perhaps further action by the government or perhaps by the individuals or organizations that might adopt the guidelines as the appropriate standard for application.

CONFU also had substantive limits. The original, self-imposed agenda called for discussion and possible guidelines on numerous topics. ${ }^{141}$ In the end, only three proposals for guidelines on fair use emerged from the process. ${ }^{142}$ The other topics fell aside for different reasons. ${ }^{143}$ Some topics were dropped because influential participants insisted. For example, one topic was the fair use of printing or downloading a single copy of an item found on the Internet for personal use or study. The Association of American Publishers objected sharply to any discussion that could lead to identifying fair use of such activity, explaining that it was reserving the right to monitor and charge fees for such uses. ${ }^{144}$ The topic fell off the agenda. ${ }^{145}$ Topics such as "browsing" proved to be

134 Heather Florence, Copyright Reform and Licensing Practice, 557 PLI/PAT 123, 26667 (1999).

135 Klingspom, supra note 1 , at 114 (referring to the failure of CONFU to meet its goals).

136 See, e.g., H.R. REP. No. 94-1476, at 67, 70 (1976).

137 See, e.g., H.R. REP. No. 94-1476, at 72 (1976) (noting opposition by the American Association of University Professors and the Association of American Law Schools to the Classroom Guidelines).

138 GREEN PAPER, supra note 38, at 134.

139 CONFU FINAL REPORT, supra note 4, at 18.

$140 \mathrm{Id}$. at 10.

${ }^{141} \mathrm{Id}$. at 27 (listing twenty-one topics, ranging from "what is a classroom" and "what is a library" to encryption, transient copying, permissions, and purpose of fair use).

142 Digital-Images Guidelines, Distance-Learning Guidelines, and Multimedia Guidelines, see supra note 4, and infra Part II.C.2-4.

143 CONFU FNAL REPORT, supra note 4, at 27.

144 The present author attended most of the CONFU meetings, and these statements from the AAP representative are from the author's notes of the meeting. 
too nebulous for the group to define and comprehend consistently. 146 The use of software in libraries was addressed in alternative terms; the issues were not strictly fair use, but rather arose under relatively clearly defined statutory provisions of sections 108 and 109 of the Copyright Act. ${ }^{147}$

The important issues of fair use related to making materials available in electronic-reserve systems and through interlibrary loan moved significantly toward draft guidelines, ${ }^{148}$ but the effort did not yield finished documents that were brought into the final CONFU report by consensus of the participants. ${ }^{149}$ The failure of CONFU to elaborate on numerous topics or to formally adopt draft standards on a few critical issues reveals various limits in the dynamics of CONFU. ${ }^{150}$ Some fair-use issues were apparently too unsettled or relatively unimportant; other issues were too contentious or perhaps simply too important to engender meaningful concession and compromise as is necessary in successful negotiations. ${ }^{151}$

145 CONFU FinAL REPORT, supra note 4, at 27 ("Topic deemed inappropriate for guidelines.').

146 Id. ("Given concerns over terminology, CONFU agreed not to proceed with a statement.").

${ }^{147}$ Id. at 17 (" $[1]$ t was generally agreed by CONFU participants that, since the scenarios developed by the working group clearly illustrated the general rules and how particular uses of computer program software in libraries either complied with or violated the Copyright Act, theтe was no need to draft separate guidelines."). See also Statement on Use of Copyrighted Computer Programs (Software) in Libraries-Scenarios, CONFU FNAL REPORT, id., at 61-65.

148 CONFU FINAL REPORT, supra note 4, at 27 (For electronic reserves, "CONFU could not proceed with guidelines;" for interlibrary loan, document delivery, and electronic document sharing, the "Working Group agreed that it was premature to draft guidelines for digital transmission of digital documents.").

149 CONFU operated without any explicit or clear procedures, but rather by consensus. No one can say with any definitiveness whether guidelines are in or out of the report with support from a majority or from any set of influential participants. The present author was involved in efforts to develop guidelines for electronic resources. For this author's views on the failure of CONFU to formalize those guidelines, see Crews, Electronic Reserves, supra note 39.

150 One study puts the reason for the failure of CONFU more bluntly:

Nearly three years and thousands of dollars and human hours later, the parties could not come to a consensus on guidelines in any of the areas. One explanation for the impasse was that academics and other educational users of copyrighted information felt the proposed guidelines were too restrictive (preferring the uncertainty of the law and the four-prong test to the proposed guidelines), while publishers seemed to believe they were being asked to relinquish more control over the use of their materials in the context of fair use than was desirable.

Stephan I. Colbert \& Oren R. Griffin, The Impact of "Fair Use" in the Higher Education Community: A Necessary Exception?, 62 ALB. L. REv. 437, 456 (1998) (footnotes omitted).

151 Several studies have examined the basic factual background of CONFU and summarized the features of the proposed guidelines. See, e.g., Kent D. Stuckey, Internet and Online Law, 526 PLI/PAT 419, 546 (1998); Needham J. Boddie, II, et al., A Review of Copyright and the Intemet, 20 CAMPBELL L. REV. 193, 246-259 (1998). 


\section{Multimedia Guidelines}

These guidelines, formally entitled "Proposal for Fair Use Guidelines for Educational Multimedia,"152 apply to the digital "cutting and pasting" of various works to make a unified multimedia project for use in the classroom setting. ${ }^{153}$ They evolved through the deliberations of CONFU meetings, but they also took shape in a parallel set of meetings, with many of the same participants, organized and hosted by the Consortium of College and University of Media Centers (CCUMC). ${ }^{154}$ These guidelines were not the exclusive domain of CONFU simply because the CCUMC began the process of developing them at an earlier date. ${ }^{155}$ They were soon brought within the purview of CONFU. ${ }^{156}$

The CCUMC openly explored the prospect of such guidelines at a public conference held in Washington in June 1994.157 Again, diverse parties with diverse interests in the outcome attended to discuss possible fair-use guidelines. CCUMC largely represents directors of media centers from educational institutions around the country, and they expressed serious concerns about the pressures they faced to utilize media technology for educational purposes in ways that raise troublesome questions about fair use and copyright infringement. They often felt caught between expectations of faculty members who seek greatest utility of technology, and the threat of legal liability to third-party copyright owners. The guidelines were an effort to mediate that tension.

Working closely with representatives from industries in the fields of print publication, music, video, and motion pictures, the CCUMC led the effort to devise the guidelines. ${ }^{158}$ They were also explicitly seeking to follow, in many respects, the model of the Classroom Guidelines and other earlier standards. 159 After more than two years, the guidelines took a completed shape that many of the participants were prepared to endorse. ${ }^{160}$ The finished document is a lengthy

152 Multimedia Guidelines, supra note 4, at 49.

$153 \mathrm{Id}$. at 50 . CONFU offered this definition of a multimedia work: "In general, multimedia projects are stand-alone, interactive programs incorporating both original and preexisting copyrighted works in various media formats." Id.

154 CONFU FNAL REPORT, supra note 4, at 14.

$155 \mathrm{Id}$.

156 Id. at $14-15$.

157 See AGENCY FOR INSTRUCTIONAL TECHNOLOGY \& CONSORTIUM OF COLIEGE AND UnIVERSITY MedIA CENTERS, WHAT'S FAIR? A REPORT ON THE PROCEEDINGS OF THE NATIONAL CONFERENCE ON EDUCATIONAL FAIR ACCESS AND THE NEW MEDIA, (Washington, D.C., June 15-17, 1994).

158 CONFU FINAL REPORT, supra note 4, at 14.

159 Id. at 6 ("Participants were encouraged to follow the example of previous successful efforts to develop voluntary fair use guidelines-the Classroom Guidelines in 1976, and the National Commission on New Technological Uses of Copyrighted Works.').

${ }^{160} \mathrm{Id}$. at 15. 
and detailed attempt to define with utmost precision the parameters of fair use as applied to the wide-ranging activities and materials used in the name of multimedia development for educational purposes. ${ }^{161}$ As with all of the guidelines examined in this article, the Multimedia Guidelines are explicitly applicable only to non-profit educational uses. ${ }^{162}$ That limit is rigidly defined in this document and confined to curriculum-based uses at institutions that have education as a primary mission. ${ }^{163}$ By implication, fair use does not apply, or does not apply as broadly, to other uses or to uses in other organizations. 164

Central to these guidelines are the "portion limitations" for each type of work. ${ }^{165} \mathrm{~A}$ multimedia work may be an assemblage of text, images, sound, and other materials "cut and pasted" in digital form onto a single disk or other storage unit. ${ }^{166}$ Each of these types of works has its own limit in allowed quantity. ${ }^{167}$ For example, clips of text are limited to the lesser of either one thousand words or ten percent of the original work. ${ }^{168}$ Sound clips are limited to the lesser of either

161 Multimedia Guidelines, supra note 4, at 51. Under the Multimedia Guidelines, educational multimedia projects 'incorporate students' or educators' original material such as course notes or commentary, together with various copyrighted media formats including but not limited to, motion media, music, text material, graphics, illustrations, photographs and digital software which are combined into an integrated presentation."

162 CONFU FNAL REPORT, supra note 4, at 32. The Preamble, uniform to all CONFU guidelines, establishes that "these guidelines do not cover non-educational or commercial digitization or use at any time, even by non-profit educational institutions."

163 Multimedia Guidelines, supra note 4, at 51. "Educational multimedia projects ... under these guidelines may be used only for educational purposes in systematic learning activities including use in connection with non-commercial curriculum-based learning and teaching activities." Also, "educational institutions are defined as nonprofit organizations whose primary focus is supporting research and instructional activities of educators and students for noncommercial purposes."

${ }^{164}$ But see, H.R. REP. No. 94-1476, at 66 (1976) (stating that "the works and uses to which the doctrine of fair use is applicable are as broad as the copyright law itself').

165 Multimedia Guidelines, supra note 4, at 53 ("Portion limitations mean the amount of a copyrighted work that can reasonably be used ... regardless of the original medium from which the copyrighted works are taken.').

166 Id. at 50.

${ }^{167} \mathrm{Id}$. at 53. "In the aggregate means the total amount of copyrighted material from a single copyrighted work that is permitted to be used in an educational multimedia project without permission under these guidelines. These limitations apply cumulatively... for the same academic semester, cycle or term." Id.

${ }^{168} \mathrm{Id}$. at 53. For poems, other limitations apply:

An entire poem of less than 250 words may be used, but no more than three poems by one poet or five poems by different poets from any anthology.... For poems of greater length, 250 words may be used but no more than three excerpts by a poet, or five excerpts by different poets from a single anthology.

Id. at 54 . 
thirty seconds or ten percent. ${ }^{169}$ A multimedia project may utilize only thirty seconds of a lengthy symphony or only eighteen seconds of a three-minute popular song. 170

Even while staying within these parameters, the instructor or student who prepares the work is subject to numerous other conditions. For example, the project may be retained and used for only two years, ${ }^{171}$ although it may be part of the individual's portfolio for employment purposes. 172 Many uses beyond the limits in the guidelines explicitly require permission ${ }^{173}$-analogous to the "prohibitions" in the Classroom Guidelines ${ }^{174}$-even though the preamble to the guidelines indicates that they are "minimum" standards and that additional uses may be allowed under the law. 175

\section{Distance-Learning Guidelines}

The Distance-Learning Guidelines addressed an especially challenging interrelationship between fair use and the distance-learning provisions of section 110(2) of the Copyright Act. ${ }^{176}$ The statute allows the transmission of displays and performances of copyrighted works, but only within sharp limitations. ${ }^{177}$ First, the law sets "ground rules" for the use of works under any circumstances; in particular, the content of the course may be communicated to classrooms or other places "devoted to instruction." 178 The transmission may reach students at other locations - such as home or work-but only if their "disabilities or other special circumstances"179 prevent their coming to the classroom. Once complying with these conditions, the law allows displays of all works, but allows performances of

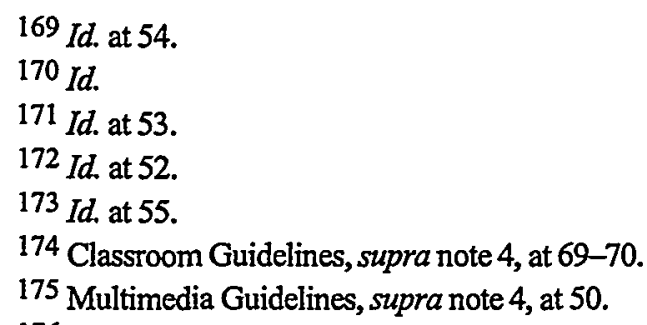

17617 U.S.C. $\$ 110(2)$ (1994). For a critical examination of the current state of section $10(2)$ and of a proposal from the United States Copyright Office to revise it see Kenneth D. Crews, Distance Education and Copyright Law: The Limits and Meaning of Copyright Policy, 27 J.C. \& U.L. $15(2000)$.

177 Section 110(2) allows the transmission of only select types of copyrighted works in distance learning. The statute allows "displays" of all types of works, but it allows the "performance" of only nondramatic literary works and nondramatic musical works. 17 U.S.C. § $110(2)$ (1994). By contrast, section 110(1) allows performances and displays in the context of "face-to-face" teaching, and it sets no limits on the types of allowed works. 17 U.S.C. $§ 110(1)$ (1994).

17817 U.S.C. $\$ 110(1)(1994)$.

$179 \S 110(2)$ (C)(ii) (1994). 
only "nondramatic"180 musical or literary works. Audiovisual works are not allowed at all in transmissions for distance learning. 181

The guidelines from CONFU were an attempt to use the terms of section 107 on fair use to reach beyond the rigors of section $110(2){ }^{182}$ Fundamentally, the guidelines are a deliberate move away from the troublesome delineation between works that are allowed and not allowed in distance learning. ${ }^{183}$ The guidelines drop the classification of "dramatic" and "nondramatic" works and the ban on audiovisual works, but the guidelines allow the broadening of works only on secured transmissions, and generally only for live or "synchronous" transmissions of the instructional experience. ${ }^{184}$ Only enrolled students at nonprofit educational institutions who are receiving the content at permitted locations where further reproduction may be controlled may receive these transmissions. ${ }^{185}$ Moreover, the guidelines allow only a single use of each work by each instructor, any repeat use for future classes requires permission. ${ }^{186}$ Within these conditions, the instructor may display or perform the entire work-which includes showing an entire videotape to the class. ${ }^{187}$

"Asynchronous" transmissions - often where the material resides on a computer server or other device and may be accessed by the students at their discretion-proved to be highly problematic for the negotiators. Publishers and other copyright owners expressed deep concern about the possibility that students would be able to download and further reproduce or disseminate the materials, thereby circumventing passwords or other restrictions on access and undercutting markets for the materials. ${ }^{188}$ These guidelines from CONFU do not rule out that

$180 \S 110(2)$ (1994).

181 § 101 (1994) (defining "literary work" to exclude audiovisual works).

182 Section 110(2) of the Copyright Act sets highly problematic and restrictive limits on the use of copyrighted works in distance learning. See, e.g., Kenneth D. Crews, Copyright and Distance Education: Displays, Performances, and the Limitations of Current Law, in GASAWAY, GROWING PAINS, supra note 7, at 377, 393-94.

183 Distance-Learning Guidelines, supra note 4, at 44-45.

184 Id. at 46 .

185 Id. at $46-47$.

${ }^{186}$ Id. at 46 ("For subsequent performances, displays or access, permission must be obtained."). Cf. Off-Air Guidelines, supra note 4, at 8 (allowing single performance of a videotape recorded "by individual teachers in the course of relevant teaching activities, and repeated once only when instructional reinforcement is necessary"').

${ }^{187}$ Distance-Learning Guidelines, supra note 4, at 46. "Works performed must be integrated into the course, must be part of systematic instruction and must be directly related and of material assistance to the teaching content of the transmission. The performance may not be for entertainment purposes." In addition, "[p]erformance of an entire copyrighted work or a large portion thereof may be transmitted only once for a distance learning course." $I d$.

${ }^{188}$ This concern as a practical matter is likely to grow in the future as technology evolves. It may well be addressed, however, in the Digital Millennium Copyright Act, which creates a new federal offense for the circumvention of technological measures that protect copyrighted 
fair use may apply to asynchronous transmissions, but they openly acknowledge that the parties were simply unprepared to reach agreement at that time. ${ }^{189}$

\section{Digital-Images Guidelines}

The Digital-Images Guidelines are perhaps the most awkward of all the guidelines to emerge from CONFU. 190 They are set forth in a lengthy document that seeks at its core to articulate when a library or educational institution may make a digital version of a photograph or other image and make it available for teaching and research. 191 While this subject may appear to be relatively focused in its scope, the legal issues actually became extraordinarily intertangled. The result is a complex and convoluted set of guidelines.

The use of visual images poses distinct challenges for applying fair use. ${ }^{192}$ The use will most likely require the entire work, a fact that most often weighs against fair use. ${ }^{193}$ A photograph may also be a highly creative work, which also

works. Thus, the college or university may transmit content, but impose passwords as a condition of access. Defeating or circumventing such measures may be a new form of federal offense that gives rise to civil and criminal penalties. Copyright owners strongly supported that legislation in order to give added assurance that their materials would be better protected in a digital environment. Thus, this new legal protection should allow greater assurance of protection when applied in the distance-learning context to control use and prevent misuses of content. See Digital Millennium Copyright Act, Pub. L. 105-304, 112 Stat. 2860 (1998). For an examination of events leading to development of the Distance-Learning Guidelines and the critical attacks on them, see Laura N. Gasaway, Guidelines for Distance Learning and Interlibrary Loan: Doomed and More Doomed, 50 J. AM. SOC'Y FOR INFO. SCI. 1337 (1999).

189 Distance-Learning Guidelines, supra note 4, at 45. "Although the participants believe fair use of copyrighted works applies in some aspects of [asynchronous delivery of distance learning], they did not develop fair use guidelines to cover these situations because the area is so unsettled." Id. True, these developments in distance learning are "unsettled," but they are not likely to become any more settled in the near future. This stated reason for not addressing asynchronous distance learning likely conceals more realistic reasons: it poses too large a risk to copyright owners to win their acceptance of guidelines that acknowledge or concede fair use. For further discussion of the background of these guidelines see Gasaway, supra note 188.

${ }^{190}$ Phan, supra note 1, at 198-201 (highly critical of the Digital-Images Guidelines).

191 Digital-Images Guidelines, supra note 4, at 36-37, 40.

192 CONFU FINAL REPORT, supra note 4, at 10. "It was recognized at the outset of CONFU that digital images collections raise issues different from text issues; that these considerations and concerns were not addressed by text norms and understandings (e.g., quality/distortion/accuracy issues, commercial exploitation potential, and the critical mass necessary for educational uses)." Id. Since issuance of the Digital-Images Guidelines, a district court has ruled that the use of "thumb-nail" versions of photographs in search engines to locate them on the Internet is permitted under fair use. Kelly v. Arriba Soft Corp., 77 F. Supp. 2d 1116, 1121 (C.D. Cal. 1999). See also Nunez v. Caribbean Int'l News Corp., 235 F. 3d 18 (1st Cir. 2000) (holding that the reproduction of photographs as a news item is fair use).

193 See, e.g., Sony Corp. of Am. v. Universal City Studios, Inc., 464 U.S. 417, 449-50 (1984); Am. Geophysical Union v. Texaco Inc., 60 F.3d 913, 925-26 (2d Cir. 1995). 
generally weighs against fair use. ${ }^{194}$ Moreover, a single photograph may involve layers of legal claims. The photographer may hold the copyright, but the photograph may capture the image of a painting or other copyrighted work, or of a sign that has trademark protection, or of a person who has rights of privacy or publicity. ${ }^{195}$ The image may be from a book or slide collection, to which a publisher other party holds a compilation copyright. These circumstances give rights to multiple claimants with respect to one visual image.

The Digital-Images Guidelines met this challenge in a most complex manner. These guidelines allow faculty and others to make digital versions of analog images, but subject to numerous conditions that are not clearly articulated. Images may be made and presented in forums such as the face-to-face classroom and in peer conferences, but generally the images may be accessed only on a "secure electronic network" and only for "one academic term." Those restrictions are reasonable, if not modest, but the guidelines are, overall, far from such a simple and clear approach. The language of this document is convoluted, verbose, and obscure. The measure of fair use is repeatedly hedged with admonitions about the need to secure permission and to keep records of all efforts. If some specific activity is outside an elaborately sanctioned provision, the guidelines repeatedly refer users back to "the four-factor fair use analysis" under the law. The standards outlined in the guidelines are presented as if they are not only a "safe harbor" from liability, but a safe harbor from fair use as well. For those parties who might accept the Digital-Images Guidelines, they seem to offer explicitly an alternative to-or escape from-the need to understand fair use. 196

\section{Three Classes of Fair-Use Guidelines}

This lineage of fair-use guidelines underscores that while many of the guidelines have some common traits, they also have many critical differences. For purposes of analyzing their legal standing, the guidelines may be grouped into three categories: (1) privately developed guidelines that have congressional recognition in legislative history of the copyright law; ${ }^{197}$ (2) guidelines developed

194 See, e.g., Rogers v. Koons, 960 F.2d 301, 310 (2d Cir. 1992) (referring to the "nature" factor, the court found that "[s]ince 'Puppies' was creative and imaginative and Rogers, who makes his living as a photographer, hopes to gain a financial return for his efforts with this photograph, this factor militates against a finding of fair use").

195 See Bridgeman Art Library, Ltd. v. Corel Corp., 36 F. Supp. 2d 191 (S.D.N.Y. 1999) (holding that a photograph of a public-domain work of art does not have copyright protection).

196 Sharon Appel, Copyright, Digitization of Images, and Art Museums: Cyberspace and Other New Frontiers, 6 UCLA ENT. L. REV. 149, 232 (1999) (arguing that the CONFU Guidelines will not solve the copyright problems of museums, and the potential liability "contravenes the essential purpose of copyright law, and threatens the ability of museums to carry out their mission in the electronic times in which we live").

197 Classroom Guidelines, Music Guidelines, Off-Air Guidelines, supra note 4. 
by a duly authorized governmental commission; 198 and (3) privately developed guidelines that have been endorsed or supported by administrative agencies. ${ }^{199}$ Invariably, these classifications are not entirely discrete. Some overlap of characteristics among the guidelines does occur. Yet these classifications are intended to isolate and identify the salient attribute of each set of guidelines that purports to give them "official" or "legal" status. By making this classification, the analysis can begin to test the significance of that status for attributing legal validity to each of the fair-use interpretations.

\section{Guidelines and Legislative History}

The Classroom Guidelines, the Music Guidelines, and the Off-Air Guidelines are in this category. Each of these standards was the product of private negotiations, but the finished work was submitted to Congress for review. ${ }^{200}$ At no time did any of these guidelines advance in Congress toward legislation. In fact, the earliest of the guidelines grew out of exactly the opposite situation. They were a direct response to a known unwillingness of Congress to legislate the details of fair use. Yet with respect to each of these guidelines, members of Congress expressed approval.

\section{Guidelines and Congressional Commissions}

The CONTU Guidelines are the only fair-use guidelines forthcoming from a congressional commission. ${ }^{201}$ While the CONTU commission had no authority to make law, it was a commission charged by an Act of Congress and acting. consistently with that charge in developing guidelines under the auspices of the source of copyright law-Congress. ${ }^{202}$ In that regard, these guidelines may be understood as emerging from a more authoritative source than, for example, guidelines that result from negotiations among private parties. Not only is such a commission closely connected to a law-making authority and charged by that authority to act, but such a commission will be accountable to that authority in the end.

When the CONTU Commission completed its work and submitted its final report in 1979, it delivered its findings and recommendations to Congress. ${ }^{203}$ The significance of accountability was vivid from the outset. One recommendation,

198 CONTU FINAL REPORT, supra note 4.

199 CONFU FINAL REPORT, supra note 4.

200 H.R. REP. No. 94-1476, at 67, 70 (1976).

201 See CONTU FINAL REPORT, supra note 4, at 3 .

202 See supra text accompanying note 101.

203 See generally, CONTU FINAL REPORT, supra note 4. 
for example, was a revision of section 117 of the Copyright Act, 204 governing the use of computer software. ${ }^{205}$ Congress enacted that recommendation in 1980.206 The commission members must certainly have recognized that its recommendations must be balanced and reasonable to win congressional approval. Similarly, when CONTU recommended the guidelines for interlibrary loans, its members surely must have perceived the need to be fair and balanced simply to gain acceptance and to avoid rejection. The public might accept or reject the guidelines as they seek to follow them. Congress could also have accepted or rejected the CONTU recommendations.

The work of CONTU was also accountable to legal precedent. In particular, the interlibrary-loan guidelines were built on the foundation of a statute-section $108^{207}$-and a case-Williams \& Wilkins Co. v. United States. ${ }^{208}$ Those existing developments provided a relatively specific standard against which to evaluate any recommended guidelines. For the guidelines to be accepted in the legal community and by librarians, they must bear strong fidelity to the statute and the case. Critics would be able to undermine the credibility of the commission's work if it strayed far from existing law. Thus, not only was the commission accountable to Congress, an authoritative source of law, but it was also more clearly accountable to the law itself. The relevant law in this instance was also reasonably specific.

\section{Guidelines and Administrative Agencies}

The CONFU guidelines are the work of an informal gathering of interested parties acting under the auspices of federal agencies, principally the United States Patent and Trademark Office. CONFU arose from a suggestion in a report from the National Information Infrastructure Task Force, and the U.S. Copyright Office joined in supporting the effort. ${ }^{209}$ While the Patent and Trademark Office and the Copyright Office have some lawmaking authority, notably the issuance of regulations on limited matters, ${ }^{210}$ neither organization has the authority to provide any rulings or elaborations on the meaning of fair use under copyright law. In fact, the Copyright Office distributes widely a form letter explaining that it does

204 17 U.S.C. \$117 (Supp. IV 1998).

205 CONTU FINAL REPORT, supra note 4, at 1.

206 Pub. L. No. 96-517, 94 Stat. 3015, 3028 (1980).

207 17 U.S.C. $\$ 108$ (1994 \& Supp. IV 1998).

208487 F.2d 1345 (Ct. Cl. 1973). This case is examined in detail at infra Part III.C.

${ }^{209}$ GREEN PAPER, supra note 38, at 134. ("[T] he Working Group will sponsor a conference to bring together copyright owner and user interests to develop guidelines for fair uses of copyrighted works by and in public libraries and schools.")

210 See 17 U.S.C. $\$ \$ 701-710$ (1994 \& Supp. IV 1998) (providing the general authority of the Copyright Office to act on specified matters). 
not answer inquiries from the public about the meaning of fair use.211 The Copyright Office, however, long has issued a "circular" that provides general information about the law of fair use and reprints the earlier fair-use guidelines. ${ }^{212}$

CONFU was therefore acting under the guidance of federal agencies that obviously have no authority to make law relevant to fair use. They have no specific authority to convene and empower a group to adopt binding standards. Moreover, these administrative agencies had no authority to respond in any binding way to any recommendations that emerge from CONFU. When the CONTU Commission delivered its final report in 1979, it delivered it to Congress and to the President, and Congress had the power to act on many of the recommendations. ${ }^{213}$ Congress could have rejected the interlibrary-loan guidelines as inconsistent with the law of section 108. In contrast, when CONFU delivered its final report in 1998, it delivered it to the Commissioner of Patents and Trademarks, the head of an agency with no authority to give any recommendations with a binding stature. ${ }^{214}$ Acceptance or rejection by that agency might reveal a point of view or bolster a particular objective, but it would have no legal authority.

In a gesture that tacitly acknowledged those limits of the CONFU process, supporters of the Multimedia Guidelines seemed to perceive that congressional imprimatur could lend the guidelines greater significance or possible authority. In September 1996 those supporters took the draft guidelines to members of the Intellectual Property Subcommittee of the U.S. House of Representatives and obtained a signed, "nonlegislative report" that offered a general endorsement of the guidelines. ${ }^{215}$ Recognizing the authority of Congress to make copyright law, approval from a subcommittee-albeit vaguely stated-was a significant step toward bestowing the appearance of law on the guidelines. ${ }^{216}$ Even viewing that

211 U.S. COPYRIGHT OFFICE, FAIR USE, F.L. 102 (1993) ("The Copyright Office can neither determine if a certain use may be considered 'fair' nor advise on possible copyright violations. If there is any doubt, it is advisable to consult an attorney."). That form letter is available at http://cweb.loc.gov/copyright/fls/fl102.pdf (last visited April 4, 2001).

212 See U.S. Copyright Office, CIRCULAR 21: REPRODUCTION OF COPYRIGHTED WORKS BY EDUCATORS AND LIBRARIANS, at http://lcweb.loc.gov/copyright/circs/circ21.pdf (last visited April 4, 2001).

213 CONTU FNAL REPORT, supra note 4, at 1.

214 Id.

215 MULTIMEDIA COMMITTEE PRINT, supra note 4.

216 The nonlegislative report from the subcommittee stated in part: "the Subcommittee congratulates" the developers of the Multimedia Guidelines "for their hard work and effort, which clearly advances the strength of the U.S. copyright system." Id. More substantively, the report makes this statement:

While only the courts can decide whether a particular use of a copyrighted work fits within the fair use exemption, these guidelines represent the participants' consensus view of what constitutes the fair use of a portion of a work which is included in a multimedia educational project. The specific portion and time limitations will help educators, scholars and students 
development most generously, support from a subcommittee hardly makes the guidelines law. In the final analysis, the CONFU guidelines are partly the work of one or more federal agencies, perhaps seeking to serve important goals, but ultimately acting without authority to create results that are binding on any party.

\section{JUDICIAL DECISIONS AND FAIR-USE GUIDELINES}

While the fair-use guidelines have had a central function of assisting educators, librarians, and other individuals as they apply fair use in common situations, the guidelines also have shaped several judicial decisions. Some of those decisions provide detailed applications of the guidelines to the given facts, often with insightful discussion of the legal standing of the fair-use interpretations. Other decisions have offered only passing mentions of the guidelines. Each of these court opinions is important in its own way. The detailed examinations provide essential scrutiny of the guidelines, allowing readers to examine the court's comprehension of fair use and the negotiated guidelines. The brief references in several other cases are also vital. A few words from a court can be rife with meaning. A court may summarily articulate a conclusion, or a few words may reveal the court's understanding of the role and importance of the guidelines. This Part III of the article will survey those cases and analytically discern from them the legal significance of the guidelines in the eyes of the federal judiciary.

\section{A. Courts and the Classroom Guidelines}

\section{Association of American Publishers v. New York University}

The first infringement litigation against photocopying for educational uses arose not long after the fair-use statute took effect on January 1, 1978. In 1980 and 1981 publishers brought copyright actions against two for-profit shops that were photocopying materials for student use. The parties settled both cases, and the settlement included an agreement that the shops would adhere to the

more easily identify whether using a portion of a certain copyrighted work in their multimedia program constitutes a fair use of that work. They grant a relative degree of certainty that a use within the guidelines will not be perceived as an infringement of the Copyright Act by the endorsing copyright owners, and that permission for such use will not be required. The more one exceeds these guidelines, the greater the risk that the use of a work is not a fair use, and that permission must be sought.

Id. at 2. A lawyer may not confuse such ambiguous statements with the law, but an educator who may be inclined to find an "answer" to fair use or who may be seeking protection from liability could easily find comfort in such words from a congressional source. 
Classroom Guidelines as a limit on fair use. ${ }^{217}$ Faculty at colleges and universities, however, have an enormous range of places and possibilities for securing photocopies of class materials, and the publishing industry faced the daunting prospect of litigation against numerous shops and other outlets. To make the point of copyright infringement directly against educators, publishers filed a lawsuit against New York University (NYU) and several named faculty members in December, 1982.218 Only four months later, the parties settled that suit as well. ${ }^{219}$ Again; the settlement incorporated the Classroom Guidelines. ${ }^{220}$ This time the guidelines were adopted as the formal standard of fair use at NYU-a major research university. 221

The incorporation of the guidelines in the NYU settlement had several consequences of tremendous importance. ${ }^{222}$ First, the measure of fair use in the guidelines became the formally adopted standard at a major university and established a precedent or model that other institutions could follow. Second, other institutions did follow it. They followed it out of concern that they also may face unwanted litigation. They followed it because the publishing industry sent hundreds of letters to colleges and universities throughout the country urging them to adopt the guidelines or face a risk of litigation. ${ }^{223}$ Third, the NYU settlement restructured the Classroom Guidelines into an even more rigid standard than was embodied in the original version. That rigid version became the model or precedent that other institutions often adopted. Of particular note, the

${ }^{217}$ Harper \& Row, Publishers, Inc. v. Tyco Copy Servs., Inc., COPYRiGHT L. DEC. (CCH), I 25,230 (D. Conn. 1981); Basic Books, Inc. v. The Gnomon Corp., CopYRIGHT L. DEC. (CCH), $\{25,145$ (D.C. 1980).

218 Addison-Wesley Publ'g. Co. v. N. Y. Univ., No. $82-8333$ (S.D.N.Y. filed Dec. 14, 1982). See, e.g., Edwin McDowell, Nine Publishers Sue NYU, Charging Copyright Violation, N.Y. TMMES, Dec. 15, 1982, at C34.

219 Copyright Infringement and Photocopying for the Classroom: The Association of American Publishers v. New York University Settlement, in 1983 ENTERTAMMENT, PUBLISHING AND THE ARTS HANDBOOK 313 (Michael Meyer \& John David Viera, eds., 1983). See also Addison-Wesley Publ'g. Co. v. New York Univ., No. 82 CIV 8333, 1983 WL 1134, 1983 COPYRIGHT L. DEC. (CCH) \25,544 (S.D.N.Y. May 31, 1983).

220 Addison-Wesley Publ'g. Co. v. New York Univ., 1983 WL 1134 (S.D.N.Y.), at 4-6.

$221 \mathrm{Id}$. at 6 ("The Guidelines ... are to be used to determine whether or not the prior permission of the copyright owner is to be sought for photocopying for research and classroom use. If the proposed photocopying is not permitted under the Guidelines ... permission to copy is to be sought.").

${ }^{222}$ The Classroom Guidelines are an integral part of the Policy Statement on Photocopying of Copyrighted Materials for Classroom and Research Use. This policy statement was approved by the Board of Trustees of New York University on May 9, 1983, and is available at http://www.nyu.edu/pages/osl/publications/photocopying.html (last visited April 5,2001 ).

223 Form letter from Townsend Hoopes, President of the Association of American Publishers, Inc., to college and university administrators. (June 10, 1983). 
NYU settlement adopted the guidelines without the opening preamble about "minimum" standards.224 Faculty making copies under the settlement were expected to follow the strict limits, not as a minimalistic safe harbor, but rather as a ceiling on fair use. Any uses beyond those limits required advance approval from university counsel. For all practical purposes, the minimum standards of the original guidelines became maximum standards at NYU.

\section{Basic Books, Inc. v. Kinko's Graphics Corp.}

One court decision questioned critically at least one major portion of the Classroom Guidelines and ultimately ruled that those guidelines, in that one respect, were not consistent with fair-use law. In Basic Books, Inc. v. Kinko's Graphics Corp., 225 several prominent commercial publishers of textbooks and other books alleged that Kinko's had infringed their copyrights by making multiple copies of lengthy excerpts from the books and compiling them into "coursepacks" or "anthologies" sold to students at nearby colleges and universities. ${ }^{26}$ Faculty members at those institutions selected the materials, and the students acquired the copies for reading in connection with specified courses. ${ }^{227}$ Kinko's at that time operated a "Professor Publishing" program to solicit from professors the business of making and selling copies. ${ }^{228}$

Based on an analysis of the four factors from section 107, the district court had little trouble concluding that the copying was not fair use. ${ }^{229}$ Only after

224 The settlement agreement with NYU provides that the university will adopt the Classroom Guidelines. It specifies that faculty will adhere to the guidelines as set forth in the appendix to the settlement. That appendix includes only the substantive standards, without the introductory language about minimum standards. That language, however, does appear in a footnote to the settlement and NYU policy in connection with a discussion of the origin of the guidelines. Still, the settlement is explicit in calling on faculty to adhere to the guidelines without inclusion of the "minimum" language. See Copyright Infringement and Photocopying for the Classroom: The Association of American Publishers v. New York University Settlement, in 1983 ENTERTAINMENT, PUBLISHING AND THE ARTS HANDBOOK 321 (Michael Meyer \& John David Viera, eds., 1983). See also Addison-Wesley Publ'g. Co. v. N. Y. Univ., No. 82 CIV 8333, 1983 WL 1134, 1983 COPYRIGHT L. DEC. (CCH) ๆ 25,544 (S.D.N.Y. May $31,1983)$.

225758 F. Supp. 1522 (S.D.N.Y. 1991).

226 Id. at 1528.

227 Id. at $1528-29,1531$.

228 Id. at $1528-29,1534$.

${ }^{229}$ In summary, the court found that the copying was for "commercial" purposes when pursued by Kinko's and not by the individual instructor or university. Id. at 1531-32 ("The amount of that profit is unclear; however, we need only find that Kinko's had the intention of making profits."). The amount, ranging from approximately five percent to twenty-five percent of the original books, was excessive. Id. at 1533-34. In addition, the court found in copying entire chapters the amount taken was "substantial because [the copies] are obviously meant to stand alone... as a complete representation of the concept explored in the chapter." Id. The 
reaching its conclusion did the court turn its attention to the Classroom Guidelines. That sequence is revealing. It affirms that the statute, and not the guidelines, is the source of the law, and by first having reached a decision based on the law, the court was free to explore the merits of the guidelines as dictum and not as a rule of law. The court even seemed reluctant to look at the guidelines at all, acknowledging that they should apply to copying by an instructor or an educational institution, and not by a for-profit copyshop. ${ }^{230}$ Yet the court found "the circumstance of copying for college students to be particularly compelling in this case."231 The court proceeded to evaluate the "brevity," "spontaneity," and "cumulative effect" of the copying, ${ }^{232}$ concluding with little surprise that the actions of Kinko's were outside the bounds of those rigorous confines. ${ }^{233}$

Not content with winning the court's rejection of fair use based on analysis of section 107 and of the Classroom Guidelines, the plaintiffs argued further that Kinko's should be held in violation of a specific "prohibition" contained in the guidelines, a provision that would bar any copying "used to create or to replace or substitute for anthologies, compilations or collective works."234 The plaintiffpublishers argued that this language was a sweeping gesture to place all coursepacks outside the ambit of fair use. ${ }^{235}$ The court refused the bait, accepting

copying also interfered with the market for the original books. Id. at 1534. Only the third factor-the "nature" of the works-weighed in favor of finding fair use. The court resolved that the materials were factual in nature and that factual works with information of public interest are more amenable to a finding of fair use. Id. at 1532-33.

230 Id. at $1535-36$ ("For a proper analysis, there must be initial consideration given to the issue of what comprises educational copying and whether Kinko's status as a for-profit corporation, and its profitmaking intent, renders outside of a Guidelines review. We believe that it does."). Other commentators have been highly critical of the court's use of the Classtoom Guidelines. According to one study:

Once again the Kinko's court missed the point. Reliance on the Agreement on Classroom Guidelines for guidance about fair use is questionable at best. The Agreement was not included in the legislative history to change the law "in any way." It does not even limit copying but instead sets forth bright line rules that indicate when teachers are within a safe harbor. Even as a safe harbor, though, the Agreement is not especially illuminating. It is so restrictive that most classroom uses are outside this safe harbor anyway. By design, the Agreement on Classroom Guidelines simply does not provide a meaningful standard for determining when classroom uses infringe.

Anderson \& Brown, supra note 13, at 156.

231 Kinko's, 758 F. Supp. at 1536 n.11.

232 See Classroom Guidelines, supra note 4, at 68, and supra text accompanying notes $71-73$.

233 Kinko's, 758 F. Supp. at 1536-37.

${ }^{234} \mathrm{Id}$. at 1537. The reference is to Part III of the Classroom Guidelines, supra note 4, at 69.

235 Id. (According to the plaintiffs, "Part III of the Guidelines 'flatly and unequivocally" prohibit[s] the copying of the sort in suit."). 
instead Kinko's urging for "a less rigid view of the meaning of the Guidelines."236 Although the court could see that the construction of anthologies may be a factor weighing against fair use, largely because the "cumulative effect [on the income to copyright owners] would be disastrous,"237 it nevertheless concluded: "We ... refuse to hold that all unconsented anthologies are prohibited without a fair use analysis." 238 The court added: "While we agree that Congress did manifest a specific apprehension of the use of anthologies, it is not clear that Congress intended strict application of this prohibition without fair use balancing.'239

In the final analysis, the Kinko's court gave the Classroom Guidelines some important credibility. ${ }^{240}$ They captured the court's attention, and they received a systematic application to a given situation. But a close reading of the case confirms that the guidelines were never given the weight of law. Moreover, the ruling undercut the guidelines in one crucial respect-the prohibition against anthologies was rejected categorically. The court also demonstrated that the guidelines are subject to close scrutiny in light of the four factors of section 107. Despite the congressional attention and the importance of having guidelines to address common fair-use dilemmas, the court was not prepared to take them at face value.

236 Id.; see also Bartow, supra note 67, at 153; Scott M. Martin \& Jonathan Zavin, Photocopying and the Doctrine of Fair Use Under the Copyright Act, in EXAMINING THE IMPLICATIONS OF THE FEIST AND KINKO'S DECISIONS 661 (1991); Eileen N. Wagner, Beware the Custom-Made Anthology: Academic Photocopying and Basic Books v. Kinko's Graphics 68 WEST'S EDUC. L. REP. 2 (1991) (agreeing that the decision did not enforce the prohibition).

237 Kinko's, 758 F. Supp. at 1537 \& n.14. In the analysis of the four factors from section 107, the court also looked to "other factors" and noted with no further explanation: "Additionally, the Classroom Guidelines express a specific prohibition of anthologies. The fact that these excerpts were compiled and sold in anthologies weighs against defendant." Id. at 1535.

238 Id. at 1537.

239 Id.

240 One study concluded that the Kinko's court gave much more weight to the Classroom Guidelines than the present analysis finds:

The court engaged in a balancing analysis of Kinko's conduct under the Agreement on Classroom Guidelines as if it were actually a controlling part of the law within the Copyright Act. Though the court initially equivocated on whether the Agreement stated the minimum or maximum allowable copying under the fair use doctrine, it ultimately determined that a "violation" of the Agreement was yet another factor to be weighed against the defendant in a fair use analysis.

Anderson \& Brown, supra note 13, at 155. 
3. Princeton University Press v. Michigan Document Services, Inc.

Princeton University Press v. Michigan Document Services, Inc.241 demonstrates the lack of resolution on some of the most common fair-use issues, and the case reveals the struggle even among federal judges over the meaning of fair use in general, and the applicability of the Classroom Guidelines in particular. ${ }^{242}$ On November 8, 1996, the Sixth Circuit Court of Appeals handed down an en banc decision concerning the $M D S$ case (the defendant is commonly called 'MDS"), holding that large-scale photocopying by a commercial copyshop for the creation of "coursepacks" was not fair use. The decision in many respects is an affirmation of the earlier Kinko's ruling, ${ }^{243}$ and it held that similar copying, also by an off-campus for-profit shop, was not fair use. ${ }^{244}$ Not only do reasonable experts disagree about fair use, but so do reasonable jurists, as eight judges agreed that the copying was infringement and five judges dissented and believed the activities to be within the scope of fair use. ${ }^{245}$

24199 F.3d 1381 (6th Cir. 1996).

242 The various amicus briefs filed in the case on appeal also evidence the strong interest in this case. For example, the brief filed on behalf of eleven copyright law professors is published at L. Ray Patterson, et al., Brief Amicus Curiae of Eleven Copyright Law Professors in Princeton Univ. Press v. Michigan Document Servs., Inc., 2 J. INTELL. PROP. L. 183 (1994).

243 Basic Books, Inc. v. Kinko's Graphics Corp., 758 F. Supp. 1522 (S.D.N.Y. 1991).

${ }^{244} M D S, 99 \mathrm{~F} .3 \mathrm{~d}$ at 1383 . The en banc ruling and the earlier three-judge panel from the Sixth Circuit showed that federal judges were far from a like mind on this case. In a February 1996 ruling, two of the three appellate judges held that the copying was fair use. The Sixth Circuit, on accepting the decision for rehearing en banc, vacated this decision. With the November 1996 decision, the court affirmed the decision of the District Court for the Eastern District of Michigan, which had entered summary judgment for the publishers. See Princeton Univ. Press v. Mich. Document Servs., Inc., 855 F. Supp. 905, 913 (E.D. Mich. 1994). See generally Denise K. Magner, Federal Appeals Court Eases Copyright Rules for "Course Packs, "CHRON. OF HIGHER EDUC., Feb. 23, 1996, at A20. (reporting the appellate ruling in favor of fair use).

${ }^{245}$ The decision from the Sixth Circuit is seriously problematic in many respects. Notably lacking is a detailed and insightful analysis of the four factors of fair use. Indeed, the court acknowledged that it provided only sparse comment on two of those factors. MDS, $99 \mathrm{~F} .3 \mathrm{~d}$ at 1389-90 (examining only briefly the "nature" and "amount" factors). The court reversed the order of the factors, examining the "effect" factor first, and attributing greater weight to it: "We take it that this factor, 'the effect of the use upon the potential market for or value of the copyrighted work,' is at least primus inter pares, figuratively speaking, and we shall turn to it first." Id. at 1385-88. Further complicating the legal analysis, the court also resolved that when the challenged activity is "commercial," as in this case, the burden of proving adverse market effect is on the defendant, and the use is presumed unfair until the defendant proves otherwise. Id. at 1385-86. The concept of presumptions shaping the fair-use analysis is rooted in recent U.S. Supreme Court decisions, but the validity of that approach remains open to debate. Moreover, this decision, as others, does not carefully distinguish whether the presumption is against a conclusion of fair use or applies with respect to one factor only. For decisions from the Supreme Court that struggle with the creation and application of presumptions, see Campbell $v$. 
The majority based most of its decision on a finding of potential adverse market effects that could result from photocopying, which, if "widespread," would threaten the stream of revenue from permissions that the plaintiffs had in fact been able to cultivate. ${ }^{246}$ According to the majority, the other factors were "considerably less important," and the court dealt with them "relatively briefly."247 The court's examination of the "amount" factor is also cursory, but focuses on the measure of copying that ranged from five to thirty percent of the original works, noting among other conclusions that MDS greatly exceeded the 1,000-word limit in the Classroom Guidelines. ${ }^{248}$ Additionally, it found with little surprise that the copying undertaken by MDS greatly exceeded the rigid, minimal standards of fair use set forth in the guidelines. ${ }^{249}$ The court justified its reliance on the guidelines by noting their appearance in congressional reports accompanying passage of the Copyright Act of 1976.250 Yet the court also pointedly noted that the Classroom Guidelines "state the minimum and not the maximum standards of educational fair use."251

One paragraph, especially its closing sentence, discloses the court's ambiguous response to the Classroom Guidelines and its view of them as minimalistic interpretations:

In its systematic and premeditated character, its anthological content, and its commercial motivation, the copying done by MDS goes well beyond anything envisioned by the Congress that chose to incorporate the guidelines in the legislative history. Although the guidelines do not purport to be a complete and definitive statement of fair use law for educational copying, and although they do not have the force of law, they do provide us general guidance. The fact that the MDS copying is

Acuff-Rose Music, Inc., 510 U.S. 569 (1994); and Harper \& Row, Publishers, Inc. v. Nation Enters., 471 U.S. 539 (1985).

246 Indeed, the court made a passing critique of an earlier case that had held more limited copying of an individual journal article for library patrons to be fair use. "A licensing market already exists here, as it did not in a case on which plaintiffs rely." $M D S, 99$ F.3d at 1388, citing Williams \& Wilkins Co. v. United States, 487 F.2d 1345 (Ct. Cl. 1973), aff'd by an equally divided court, 420 U.S. 376 (1975)."

247 Princeton Univ. Press, 99 F.3d at 1388. The court found the "purpose" to be entirely "commercial." Id. at 1386, 1388-89. The majority opinion gave no meaningful attention to the "nature" factor, noting only that the defendant acknowledged that the materials copied contained creativity or expression. Id. at 1389.

$248 \mathrm{Id}$. at $1389-90$.

249 Id. at $1390-91$.

${ }^{250} \mathrm{Id}$. at 1391. For a discussion of the origins of the Classroom Guidelines and their original appearance in the congressional report, see supra Part II.A.2.

251 Id. at 1390. 
light years away from the safe harbor of the guidelines weighs against a finding of fair use. 252

This single paragraph encapsulates several essential principles about fair use that are often obscured by confusion and misleading statements. ${ }^{253}$ First, the $M D S$ court confirms that the Classroom Guidelines are not the law. They have not been read into law in this case or any other case, and Congress has not made them law. ${ }^{254}$ Their appearance in congressional reports does not make them law. Second, the guidelines may be helpful "general guidance." 255 They may articulate useful concepts for understanding the meaning of fair use in particular circumstances, but they do not necessarily offer a definition for ultimately establishing fair use. Third, activities may be outside the ambit of the Classroom Guidelines, but they are not necessarily infringements. Indeed, the MDS court found that when activities are "light years" away from the guidelines, that fact may only "weigh against" a finding of fair use. 256 Fourth; in the court's view, the guidelines are at best a safe harbor.257 They may even be a safe harbor for a commercial copyshop, in addition to the nonprofit organizations for which the guidelines were intended. 258

252 Id. at 1390-91.

${ }^{253}$ See Michael G. Frey, Note, Unfairly Applying the Fair Use Doctrine: Princeton University Press v. Michigan Document Services, 99 F.3d 1381 (6th Cir. 1996), 66 U. CNN. L. REV. 959, 1014-15 (1998). Frey offers a similar critique of the court's use of the guidelines and takes the matter further:

What the text does not clearly indicate, however, but what the majority extracts from it, is the fact that copying which falls outside the Guidelines' safe harbor should weigh against a finding of fair use. The court's reasoning is wrong because the Guidelines were not meant to serve as an additional barrier to a finding of fair use in educational settings.

Id.; see also Gilbert Busby, Note, Fair Use and Educational Copying: A Reexamination of Princeton University Press v. Michigan Document Services, Inc., 86 KY. L.J. 675, 706-07 (1997-1998) (highly critical of the use of legislative history and the guidelines in MDS).

254 In an examination of the relevant cases, Part III of this article demonstrates that no case has adopted the guidelines as a legal standard. Part II.A.2 traces the origins of the Classroom Guidelines, also revealing that Congress never adopted them as a mandatory standard. See H.R. REP. NO. 94-1476, at 72 (1976).

255 MDS, 99 F.3d at 1391.

256 Id.

${ }^{257}$ Although some interested parties strongly object to labeling the guidelines as a "safe harbor," the MDS court explicitly pronounced them as such. See supra Part IV.A.2.

258 Of considerable significance, the court called the guidelines a "safe harbor" even as applied to a for-profit defendant, taking the concept far beyond the nonprofit setting where the guidelines are intended to apply. Id. at 1391. The label "safe harbor" defies the role of guidelines regularly espoused by many commercial publishers which may be seeking to preserve rights to bring legal action against even a nonprofit institution that has acted within the constraints of these guidelines. See infra text accompanying notes 400-02. See generally, Frey, 
Five judges dissented in three separate dissenting opinions. ${ }^{259}$ Judge Ryan wrote a detailed dissent that exceeded the majority opinion in both length and depth. ${ }^{260} \mathrm{He}$ took the majority to task on several aspects of fair use, but also devoted considerable attention to the Classroom Guidelines, arguing that they were of little significance in comprehending the law. Judge Ryan correctly noted that the guidelines are not enacted into the law, and then scrutinized the majority's reliance on the guidelines as an element of "legislative history" for interpreting the fair-use statute. ${ }^{261}$ Ryan condemned the use of legislative history and underscored strong propositions from recent U.S. Supreme Court decisions:

Despite the well-settled rule that legislative history is irrelevant and inappropriate to consider except to clarify ambiguity in the text of a statute, the majority relies upon the legislative history without identifying any ambiguity in the statute, but only because " $[t]$ he statutory factors are not models of clarity,... the fair use issue has long been a particularly troublesome one...., [and other] courts have often turned to the legislative history when considering fair use questions." I wish to emphasize in the strongest terms that it is entirely inappropriate to rely on the Copyright Act's legislative history at all. 262

Judge Ryan acknowledged that section 107 begs the need for some clarity, but he was quick to accept the duty of bringing meaning to fair use by deciding the case based on the factors in the statute. He declined to rely on guidelines:

supra note 253, at 1010 (calling application of the Classroom Guidelines to for-profit activity "strange").

259 A short dissent by Chief Judge Martin focuses on the constraining effect of copyright on the free flow of information and the needs of educators and students. MDS, $99 \mathrm{~F} .3 \mathrm{~d} 1381$ at 1393-94. A dissent by Judge Merritt adopts the argument that multiple copies for classroom use are within fair use under section 107 and ought not be further limited by the four factors. Id. at 1394-97. Judge Merritt reinforced his views by asserting the First Amendment of the U.S. Constitution in support of broader fair-use rights. Id. at 1397. The interrelationship between fair use and rights of free speech often leads courts to read the scope of fair use more broadly in order to protect the speech rights of the defendant who is using copyrighted works to advance the activities that ordinarily enjoy First-Amendment protections. See, e.g., Time Inc. v. Bernard Geis Assoc., 293 F. Supp. 130, 146 (S.D.N.Y. 1968) (allowing the use of sketches from the famous Zapruder film in a book about the Kennedy assassination).

${ }^{260} M D S, 99$ F.3d at 1397-1412. Ryan's dissent is also structured with the style and formality of a lead opinion, suggesting that the judge may have hoped to persuade his colleagues on the bench to join him, or perhaps persuade the U.S. Supreme Court, should it have reviewed this decision on appeal. The U.S. Supreme Court, however, denied certiorari. Mich. Document Servs., Inc. v. Princeton Univ. Press, 520 U.S. 1156 (1997). The parties then settled the case. See Footnotes: Michigan Copy Shop and Publishers Settle Copyright Lawsuit, CHRON. OF HIGHER EDUC., June 20, 1997, at A12 (reporting settlement terms that allowed MDS to copy no more than a single page of a protected work and required payment of $\$ 50,000$ damages).

$261 M D S, 99$ F.3d at 1412.

262 Id. at 1411 (alterations in original) (quoting majority opinion at 1390). 
"The Classroom Guidelines do not become more authoritative by their adoption into a Committee Report."263 He added:

That the Classroom Guidelines are not law should be reason enough for this court to refrain from using them to find infringement, but this is not the only reason to reject out of hand arguments based on legislative history. Committee Reports are unreliable "as a genuine indicator of congressional intent" and "as a safe predictor of judicial construction."264

Judge Ryan also may have overstated the majority's dependence on the Classroom Guidelines, though his general statements about the importance of legislative history and the lack of significance of the guidelines do bear considerable credibility. Judge Ryan may have also overstated concerns about the majority's reasoning. Had the majority relied primarily or even prominently on the Classroom Guidelines, concern about the merits of legislative history would be crucial. Instead, the majority used the guidelines in a manner similar to previous cases that have gone before: as a source of support for a decision already reached on an evaluation of the four factors. The guidelines are, quite simply, a crutch. They give some modicum of assurance to educators and librarians when the four factors leave lingering doubts. They also give assurance to federal judges who may be looking for external validation of a decision already reached, knowing that fair use is open to diverse interpretation and that eminently reasonable people can easily criticize any conclusion that anyone may reach. 265

\section{American Geophysical Union v. Texaco Inc.}

In a controversial decision from 1994, the Court of Appeals for the Second Circuit ruled that single copies of journal articles made by a research scientist for his own research program at a for-profit company may in some instances not be fair use. ${ }^{266}$ Again, the guidelines become a source of solace for a court rendering a troublesome decision. ${ }^{267}$ In its general analysis of the law, the court noted that

263 Id.

264 Id. (citation omitted).

265 See Elliott Epstein \& Andrew J. Zulieve, The Fair Use Doctrine: Commercial Misappropriation and Market Diversion, 13 ME. B.J. 142, 1467 (1998) (noting that the MDS court had little trouble ruling that the copying was not fair use, suggesting that the court did not need additional support from the guidelines).

${ }^{266}$ Am. Geophysical Union v. Texaco Inc., 60 F.3d 913, 914 (2d Cir. 1994), cert. dismissed, 516 U.S. 1005 (1995).

267 Perhaps evidencing protracted debate among the judges who decided this case, the court went so far as to amend its opinion seven months after its initial decision. The Second Circuit handed down its original decision in October 1994, but issued a significantly amended opinion in July 1995. Most remarkably, the amended opinion also came after the parties settled 
"Congress has thus far provided scant guidance for resolving fair use issues involving photocopying, legislating specifically only as to library copying, and providing indirect advice concerning classroom copying."268 With the Classroom Guidelines as virtually the only clue of congressional insight on fair use for photocopying, traces of the guidelines crept into the court's analysis of the copying involved in this case, despite the case's for-profit enterprise context. In particular, the court's analysis of the "purpose" factor examined the scientist's reason for making the copies. ${ }^{269}$ The court sympathized with the argument that copying for immediate laboratory use may well be fair use: "This is the sort of 'spontaneous' copying that is part of the test for permissible nonprofit classroom copying."270 "Spontaneity" is a concept from the Classroom Guidelines, and it appears nowhere in the law. Bringing it into the Texaco case can only be seen as an encroachment of the guidelines into law. 271

The Texaco decision alluded to the Classroom Guidelines again when the opinion struggled with language affirming that the ruling encompasses "institutional, systematic copying" and not copying "by an individual, for personal use in research or otherwise."272 In a footnote the court provides this summary of the legal weight of the guidelines: "Though these guidelines are not considered necessarily binding on courts ...., they exist as a persuasive authority marking out certain minimum standards for educational fair use ....273 In the final analysis, the Texaco decision confirms in a small way the trend apparent in all other cases addressing the Classroom Guidelines: they are not law; they are a minimal standard of fair use; they are a compelling source of congressional insight on fair use; they are a useful crutch for the courts that are struggling with fair-use ambiguities as much as are the stakeholders in the fair use debates; and they add some authority for a judicial decision that is first and foremost based on the law and not the guidelines.

their lawsuit and successfully petitioned the U.S. Supreme Court to dismiss the petition for certiorari. See id. at 913.

268 Id. at 917 (footnote and internal citation omitted).

269 Among other purposes, Texaco claimed that the copies allowed the scientist to bring less bulky copies into the laboratory, and the copies would not have to be safeguarded from damage. Id. at 919 .

270 Id.

271 See Zimmerman, supra note 71, at $411 \mathrm{n} .18$ (claiming that the ruling "calls into question the legitimacy of such copying for personal use outside the narrow parameters of the guidelines").

${ }^{272}$ Texaco, 60 F.3d at 916. The opinion also states: "In other words, our opinion does not decide the case that would arise if Chickering were a professor or an independent scientist engaged in copying and creating files for independent research, as opposed to being employed by an institution in the pursuit of his research on the institution's behalf.' Id. The court added much of this language when it amended the opinion. See supra note 267.

273 Texaco, 60 F. 3d at 919 n.5 (citations omitted). 


\section{Marcus v. Rowley}

The earliest court ruling to make any examination of the Classroom Guidelines was the 1983 decision by the Ninth Circuit Court of Appeals in Marcus v. Rowley. ${ }^{274}$ Eloise Marcus, the plaintiff, wrote a thirty-five page booklet on cake decorating and used it to teach adult-education classes. She sold copies to her students for two dollars each, and she properly included a copyright notice on all copies and registered the work with the Copyright Office. 275 Shirley Rowley, the defendant, enrolled in one of Marcus's classes and purchased a copy of the booklet. Rowley later developed her own booklet for her own classes, and eleven of the twenty-four pages in her work were copied directly from Marcus's original work. Rowley neither gave the plaintiff credit for her work nor acknowledged her copyright. 276

The Ninth Circuit ruled that the use was not fair, in a decision based on the four factors of the statute. ${ }^{277}$ As in the Kinko's case, the court turned to the Classroom Guidelines, but only after already reaching a conclusion based on the law, and only to affirm the decision already rendered. The Marcus opinion confused the fundamental nature of the guidelines in a series of contradictory statements. In one paragraph, the court noted that classroom copying "was of such major concern to Congress," that Congress "approved a set of guidelines with respect to it."278 The opinion then added that the guidelines represent "the Congressional Committees' view" of fair use. 279

In the same paragraph from Marcus, however, the Ninth Circuit first appears to have ratified the Classroom Guidelines as definitive: "The guidelines were designed to give teachers direction as to the extent of permissible copying ...."280 After giving the guidelines that conceptual boost, the court then promptly marginalized them: "The guidelines were intended to represent minimum standards of fair use."281 Once again, the Ninth Circuit seems more accurate with its second statement-the guidelines are at best a minimum measure of fair use in the educational setting. The one weighty paragraph from

274 695 F.2d 1171 (9th Cir, 1983).

275 Id. at 1173.

276 Id.

277 Id. at 1177. The court acknowledged that the then new Copyright Act of 1976 did not apply to the activities in this case, because the events occurred before the Act took effect in 1978. Yet the court noted that the fair-use doctrine was not intended to change under the new law, so the court could reliably look to the text of section 107. Id. at 1174.

278 Id. at 1178.

279 Id. The decision is referring to the Committee on the Judiciary of the House of Representatives, which issued the report in which the Classroom Guidelines first appeared. See supra note 4.

280 Id.

281 Id. 
the Marcus opinion recovers from its ambiguity and ends on perhaps its most accurate statement: "Thus, while they are not controlling on the court, they are instructive on the issue of fair use in the context of this case."282

The Marcus court proceeded to apply the Classroom Guidelines, concluding that the defendant's use of the plaintiff's booklet did not meet the standards of the guidelines. ${ }^{283}$ The court looked to the tests of "brevity" and "spontaneity," concluding, among other findings, that the copying was excessive, and that the use of the materials during three academic years was not "spontaneous."284 The court found that the defendant met the "cumulative effect" test of the guidelines, but did not include a copyright notice on the copied portions as required by the guidelines. ${ }^{285}$ For all the court's rhetoric about the guidelines as "not controlling" and as "minimum standards," 286 the court's actual analysis of the guidelines has all the appearance of treating the Classroom Guidelines as a mandatory standard of inflexible application, yet the court still was not basing its decision on them.

The best indication of the meaning of the guidelines is their position in the overall analysis of fair use within the opinion. As in the Kinko's and MDS decisions, the court turned to the Classroom Guidelines only after reaching a conclusion based on the four factors. The guidelines largely served the purpose of affirming the decision that the court had already reached. Given their relatively strict-or at least literal-application in the Kinko's, MDS, and the Marcus decisions, perhaps the real value of the guidelines is to serve as a tool for judges to find some degree of assurance about a decision that is in reality based on the factors from section 107.

\section{Bridge Publications, Inc. v. Vien}

A. 1993 ruling from the District Court for the Southern District of California was one decision in a series related to the aggressive defense of copyrights held by L. Ron Hubbard and the Church of Scientology.287 In Bridge Publications, Inc. $v$. Vien, ${ }^{288}$ the defendant was accused of reproducing or instructing students to reproduce literary works and sound recordings for use in a for-profit course

282 Id.

$283 \mathrm{Id}$.

${ }^{284} \mathrm{Id}$.

285 Id.

$286 \mathrm{Id}$.

287 Perhaps the most significant copyright infringement case involving materials owned by the Church of Scientology is Religious Tech. Ctr. v. Netcom On-Line Commun. Servs., 907 F. Supp. 1361 (N.D. Cal. 1995). Also notable is the ruling against the fair use of Hubbard's writings in a biography. See New Era Publ'n Int'l, ApS v. Henry Holt and Co., Inc., 873 F.2d 576 (2d Cir. 1989).

288827 F. Supp. 629 (S.D. Cal. 1993). 
taught by the defendant. ${ }^{289}$ The opinion glides through the four factors of section 107 with little explanation or analysis, and with little hope of finding fair use; the court swiftly concluded that all four factors weighed against the defendant ${ }^{290}$ The court added this brief look at the Classroom Guidelines:

Finally, the court finds defendant's use does not fit within the special guidelines approved by Congress as to fair use in the educational context. Defendant's copying and use of the works was not restricted to one copy for her own use in teaching. Additionally, the undisputed evidence shows defendant's copying was not limited and spontaneous, but was extensive and methodical, and consisted of copying from the same author, time after time. This is clearly not within the letter or spirit of the Congressional guidelines. 291

Aside from questioning whether the court really understood the standard prescribed in the guidelines, or whether they should apply at all to for-profit uses, the application of the Classroom Guidelines in Bridge Publications was superfluous in light of the drubbing that the court gave the defendant under section 107. Most importantly, the reference to the Classroom Guidelines was, as in Kinko's and Marcus, a mechanism available to the judge for reinforcing a determination already rendered under the statute.

\section{B. Audiovisual Works: Encyclopaedia Britannica Educational Corp. v. Crooks}

In Encyclopaedia Britannica Educational Corp. v. Crooks, 292 three plaintiff companies produced and distributed, for profit, educational audiovisual materials, mostly on videotape or sixteen-millimeter film. ${ }^{293}$ The defendants were a cooperative of public schools in upstate New York and its officers and directors. ${ }^{294}$ The cooperative, known by the acronym "BOCES," 295 was a

$289 \mathrm{Id}$. at 632 . The cursory opinion offers few details about the events in this case. It is a ruling on a motion for summary judgment, and the opinion at its most elaborate states: "Nor is there a genuine issue of fact regarding defendant's copying of, or directing the copying of, the copyrighted works. The undisputed evidence shows that defendant copied or directed her students to copy plaintiffs' copyrighted materials as part of a 'Dynamism' course which she offered for sale." Id. The opinion later refers obliquely to "sound recordings," "wholesale copying," and sales of materials to students at $\$ 3,000$ "for the same purpose intended by plaintiffs." Id. at 632, 634, 636.

290 Id. at $635-36$.

291 Id. at 636 (citation omitted).

292542 F. Supp. 1156 (W.D.N.Y. 1982).

293 Id. at 1158.

294 Id. at 1159.

295 The formal name of "BOCES" was Board of Educational Services, First Supervisory District, Erie County, New York. Id. at 1159. 
nonprofit organization funded by nineteen school districts and servicing more than one hundred schools. ${ }^{296}$ BOCES maintained an elaborate and expensive array of equipment in order to facilitate large-volume recording off-air of programs transmitted by broadcast or by cable and reproducing those tapes in quantities for the needs of members. ${ }^{297}$ Member schools could request a tape, which BOCES would make and deliver, and the instructor could play the tape, generally five or six times, for showing to different sections of a particular class. ${ }^{298}$

The court focused on the four factors of section $107^{299}$ and found little support for the claim of fair use,,$^{300}$ despite some sympathy for the nonprofit

296 Crooks, 542 F. Supp. at 1159.

297 Id. at 1162.

298 Id. at 1163.

299 The case involved activities that occurred before and after January 1, 1978, the effective date of the Copyright Act of 1976 , so the text of section 107 was technically not applicable to all claims of fair use by the defendants. Id. at 1160 . The court acknowledged that discrepancy, but was little troubled by it: "Section 107 ... which, although not controlling in all instances here, is intended to be a codification of preexisting law." Id. at 1168 . The defendants unsuccessfully argued that the taping was merely "time-shifting," building upon another case that found "time-shifting" for private home recording to be fair use. Id. at 1163. In the early 1980s, the precedent for time-shifting as fair use was Universal City Studios, Inc. v. Sony Corp. of Am., 480 F. Supp. 429 (C.D. Cal. 1979), a case that was destined for the United States Supreme Court, which would also hold that private off-air recording of non-subscription television broadcasts is fair use. See Sony Corp. of Am. v. Universal City Studios, Inc., 464 U.S. 417 (1984). By the time of deciding Crooks, however, the Sony case had been appealed to and decided by the Ninth Circuit Court of Appeals, which ruled that the taping was not fair use. See Universal City Studios, Inc. v. Sony Corp. of Am., 659 F.2d 963 (9th Cir. 1981). Despite the potential applicability of the Sony decisions, and their mixed results, the court in Crooks found them to be little help:

Both this case and the conflicting Sony decisions evolve from the relationship of the copyright laws to the use of new and similar technologies. Beyond this threshold, however, the similarity ends. The analyses of fair use and the copyright laws in the Sony opinions are at times helpful and instructive to the legal issues presented here, but the Sony cases are, in comparison to the instant case, "no more like than an apple to an oyster." Of foremost concern here are the copyright laws and their application to off-the-air videotape recordings used for classroom educational use.

Crooks, 542 F. Supp at 1169 (footnote omitted).

300 The court found an improper purpose in light of the "highly sophisticated" system for copying, the lack of "spontaneity," and the multiple copying. Crooks, 542 F. Supp. at 1175. The court also found that the films were educational in "nature" which tipped against fair use in order to protect the educational market and the revenues from it. Id. at 1177-78. The court found that the work was also "out-of-print," which could have helped tip the "nature" factor toward a finding of fair use. Id. at 1177. The relevance of a work being out-of-print has had mixed consequences for fair use. Most authority is consistent with the Crooks decision, holding that if a work is out-of-print, fair use can apply more liberally. See Maxtone-Graham v. Burtchaell, 803 F.2d 1253, 1264 n.8 (2d Cir. 1986); S. REP. No. 94-473, at 64 (1965); H.R. 
educational purpose. ${ }^{301}$ Although this case involved off-air videotaping of broadcasts, and the Off-Air Guidelines had been published in the Federal Register the year before, the court never mentioned them. ${ }^{302}$ The Classroom Guidelines, however, did influence the reasoning. The court noted the defendant's lack of "spontaneity,"303 a concept derived from the guidelines. ${ }^{304}$ The Classroom Guidelines were especially salient when the court determined that the "effect" factor weighed heavily against fair use. ${ }^{305}$ In a peculiar twist on a concept from the guidelines, the court noted: 'The cumulative effect of BOCES' massive videotape copying indicates that there would be no market whatsoever for plaintiffs' videotape sales or licensing agreements if off-the-air videotaping of plaintiffs' works is permitted to continue in an unregulated fashion." ${ }^{306}$ Under the guidelines, "cumulative effect" was defined with precise limits on the extent of copying; by the court's reasoning, cumulative effect gave rise to infringement when it occurred without "regulation" by BOCES, apparently well beyond strict numerical limits. ${ }^{307}$ Such an analysis leaves open the prospect that "cumulative effect," if within reasonable policy limits established by the defendant, could in fact be adverse to the plaintiff, but not so adverse as to tip the fourth factor against a finding of fair use. 308

REP. No. 94-1476, at 67 (1976). By contrast, the Kinko's decision determined that if the work is out-of-print, fair use applies more narrowly, because royalty payments for rights to make copies are the only remaining market for the work. Basic Books, Inc. v. Kinko's Graphics Corp., 758 F. Supp. 1522, 1534 (S.D.N.Y. 1991). The court also ruled that the "amount" factor weighed against fair use because of the copying and storing of full copies of films for many years. Crooks, 542 F. Supp. at 1179 . The court was adamant, however, in holding that reproductions of full copies could still be within fair use. Id. The court quoted from Williams \& Wilkins Co. v. United States, 487 F.2d 1345 (Ct. Cl. 1973): "the idea that copying an entire copyrighted work can never be fair use is an overbroad generalization, unsupported by the decisions, and rejected by years of accepted practice." Crooks, 542 F. Supp. at 1179.

301 Crooks, 542 F. Supp. at 1174.

302 For discussion of the origins of the Off-Air Guidelines, see supra Part II.A.4; see also Bell, supra note 88 at $170-77$.

303 Crooks, 542 F. Supp. at 1175.

304 See supra text accompanying note 72.

305 'The court emphasized that the off-air taping interfered with the plaintiffs' ability to market the works for educational users and "tend to diminish and prejudice the potential sale of plaintiffs' works in videotape format." Id. at 1169.

${ }^{306} \mathrm{Id}$. at $1169-70$ (emphasis added).

307 Id.

308 A crucial word here is "reasonable." BOCES had a "rough rule of thumb" that it purchased an additional copy of a film after the first copy received thirty "teacher requests." Id. at 1173. The court seemed unimpressed with the looseness of the standard and with the high ceiling on demands for copies before purchasing another original. 
When Congress enacted the Copyright Act of 1976, its reports acknowledged that some off-air taping for educational use could be fair use. ${ }^{309}$ The court, however, took a much narrower view of this possibility, noting that the House report "briefly mentions the possibility that the fair use doctrine may have some limited application to off-the-air videotaping for nonprofit classroom educational use."310 The court also looked to the Senate report, which would have allowed only "temporary use" to fit within fair use. ${ }^{311}$ In conclusion, the court resolved: 'BOCES' massive and systematic videotape copying and the retention of some master videotapes for up to ten years cannot be considered 'limited' or fair use...."312

Reliance on the Classroom Guidelines in Crooks is deeply flawed. For example, concepts of "cumulative effect" are vestiges of the Classroom Guidelines meant for photocopying; the Off-Air Guidelines for videotaping do not delimit fair use according to "cumulative effect." Turning to any of the guidelines in this case is suspect. The photocopy guidelines are not germane; the off-air guidelines were available to the court, but were not in existence at the time the infringing event occurred. But the use of the guidelines in this case is no less extraordinary than the use of the Classroom Guidelines in Kinko's or Texaco, which involved copying by a for-profit entity. ${ }^{313}$ Applying guidelines to activities occurring before the guidelines were negotiated may be inappropriate or unfair; similarly, applying the Classroom Guidelines to a for-profit defendant breaks significantly from the letter and spirit of the guidelines. Nevertheless, these decisions reveal that courts have little hesitation referring to the guidelines when they can bolster a case built on uncertain law.

In none of the relevant cases is the application of a set of guidelines a perfect fit, or even a close fit. Instead, the urge to apply the guidelines is "compelling," in the words of the Kinko's decision. ${ }^{314}$ The courts are driven to apply the guidelines in their quest for support; in turn, readers of the decisions are often drawn to the brief references to guidelines in their search for specific resolution of the fair-use issues. The circumstances seem no less compelling in the Crooks case. Perhaps

${ }^{309}$ H.R. REP. No. 94-1476, at 71 (1976) ("The Committee believes that the fair use doctrine has some limited application in this area ...."); S. REP. No. 94-473, at 66 (1975).

310 Crooks, 542 F. Supp. at 1181.

311 Id.

312 Id. BOCES also argued that making copies of audiovisual works was within its rights under section 114 of the 1976 Copyright Act, but the court noted that the argument was a stretch, given that the provision applies specifically to sound recordings. The court also used the opportunity to emphasize once again the language from H.R. REP. No. 94-1476, at 106 (1976), affirming that off-air taping is a fair-use problem. Id. at 1183.

313 For discussion of the Kinko's and Texaco decisions, see supra Parts III.A.2 and III.A.4.

314 Basic Books, Inc. v. Kinko's Graphics Corp., 758 F. Supp. 1522, 1536 (S.D.N.Y. 1991). 
they are sufficiently compelling that even though the court really did not apply the guidelines, many readers of this case have seen the silhouette of the guidelines in the court's reasoning and have called upon this case for its feeble vindication of the negotiated stance.

\section{Interlibrary Loans: Williams \& Wilkins Co. v. United States}

In the late 1960s the Williams \& Wilkins Company, publisher of various medical journals, brought suit against the National Library of Medicine (NLM) for making and distributing photocopies of its journal articles in the name of "interlibrary loans."315 As a legal action against the United States government, the case began in the U.S. Court of Claims, and the commissioner held that the copying was beyond the scope of fair use. ${ }^{316}$ On appeal, the full panel of the Court of Claims reversed, and held for the library. ${ }^{317}$ The publisher sought review by the U.S. Supreme Court, and in 1974 it split four-to-four, with one justice not participating. ${ }^{318}$ Consequently, the decision from the appellate panel was upheld, with its finding that the copying in question was fair use.

This case is of considerable importance for several reasons. It revealed the flexibility of interpreting fair use in the years leading to final passage of the 1976 Act. Stakeholders in the debate over fair use had fresh ammunition for arguing that fair use was ambiguous not only for them to apply in daily activities, but even for judges trained in the law. The case further underscored the importance of fair use for the survival of interlibrary-loan activities, and it gave judicial credence to the appropriateness of allowing fair-use copying at all for interlibrary sharing of resources. That fundamental proposition ultimately became part of the 1976 Act in section $108(\mathrm{~g})(2), 319$ and it may not have become part of statutory law had the Williams \& Wilkins case not reached a conclusion at such a propitious time.

More significant, the case is the clearest judicial signal that reasonable standards or limitations on photocopying for research purposes can pass a fair-use test, and those reasonable standards in turn became influential on the formulation of the CONTU Guidelines. 320 The NLM based its copying practices on a "General Interlibrary Loan Code" that had been adopted voluntarily by libraries cooperating in lending programs. ${ }^{321}$ As instituted at the NLM, the "Code" meant

315 Williams \& Wilkins Co. v. United States, 487 F.2d 1345, 1346-47 (Cl. Ct. 1973), aff'd by an equally divided Court, 420 US. 376 (1975). For a most enjoyable look at the strategy and events surrounding this case, see PAUL GOLDSTEN, COPYRIGHT'S HIGHWAY: FROM GUTENBERG TO THE CELESTIAL JUKEBOX 78-128 (1994).

316 Williams \& Wilkins, 487 F.2d at 1346-47.

317 Id. at 1363.

318 Williams \& Wilkins Co., 420 U.S. 376.

31917 U.S.C. $\$ 108(\mathrm{~g})(2)(1994) ;$ see also supra text accompanying notes $102-05$.

320 See CONTU FINAL REPORT, supra note 4.

321 Williams \& Wilkins, 487 F.2d at 1348. 
that the library provided only a single copy of an article from a joumal issue for each request, and each copy included a statement that it is for "study or research."322 The library also identified 104 "widely-available" journals and generally refused to fulfill copying requests until the requestor had sought the journal from nearby libraries that held those more common publications. ${ }^{323}$ The NLM, nevertheless, would fulfill the request if it came from another government library, or if the article requested was more than five years old, or if the requestor had been unsuccessful in securing the article elsewhere. ${ }^{324}$ The library adhered to other limits on the number of copies it would provide to each requestor and the number of pages it would copy from any one journal. ${ }^{325}$

These limits greatly influenced the court's ruling: "Both libraries have declared and enforced reasonably strict limitations which, to our mind, keep the duplication within appropriate confines." 326 In the end, however, the court looked to the equitable doctrine of fair use, and turned for guidance to language of committee reports surrounding the copyright revision bills then in Congress. Those reports noted the need for interested parties to convene and negotiate a resolution of a "mutual understanding" and "workable clearance and licensing conditions." 327 Lacking those resolutions, fair use depends on "all the applicable

${ }^{322}$ Id. The full statement placed on the copies was: "This is a single photostatic copy made by the National Library of Medicine for purposes of study or research in lieu of lending the original." Id.

323 Id. at 1349.

324 Id.

325 See id.

326 Id. at 1354. The court went further and drew analogy to the practice of the Library of Congress, which permitted individual library users to make their own copies on unsupervised machines which bore notices that allowed single copies "for the purpose of study, scholarship, or research." Id. at $1356 \mathrm{n} .16$. The more complete text of the notice on the machines, as included in the court's opinion, provides "a single photocopy of copyrighted material may be made only for the purpose of study, scholarship, or research, and for no other purpose" and "the sale and/or further reproduction of any photocopied copyrighted materials is illegal." Id. The court viewed the requestor in the interlibrary-loan arrangement to be little different from the user who comes to the library in person. "The reader who himself makes a copy does so for his own personal work needs, and individual work needs are likewise dominant in the reproduction programs of the two medical libraries-programs which are reasonably policed and enforced." Id. at 1355. Current law of library copying also makes no fundamental distinction between making copies for a user at the library and for a user who requests the copy from another library. In either case, the library that is actually making the copy for the user is subject to the same conditions. See 17 U.S.C. $\S 108$ (d)-(e) (1994) (allowing a library to make copies of articles and other short works, and even entire works, under specific conditions). Only when the material is sent to another library for delivery to the user is the library that requests the copy then subject to the added conditions that are the object of interpretation in the CONTU Guidelines. See 17 U.S.C. § 108(g)(2) (1994).

327 Williams \& Wilkins, 487 F.2d at 1361 (citing H.R. REP. No. 90-83, at 36 (1967)). 
criteria and the facts of the particular case." 328 The court concluded that the libraries had acted consistently with that approach and held that copying an entire article is not necessarily an infringement. ${ }^{329}$ The photocopying by the libraries was fair use..$^{330}$ In the summary of its reasons for reaching that conclusion, the court underscored its desire for Congress to take the lead in "contriving pragmatic or compromise solutions which would reflect the legislature's choices of policy and its mediation among the competing interests." 331

The court's conclusion may have been more prescient than it could have expected. Just a few years later Congress enacted section 108 , which explicitly permitted photocopies of articles and other short works for library users, whether -on location or through a request from another library. ${ }^{332}$ Congress also imposed general limitations on interlibrary arrangements, and the further elaboration of those limitations fell upon CONTU. ${ }^{333}$ The CONTU Guidelines for interlibrary loans embody many of the limitations that the Williams \& Wilkins court found to be persuasive when considering the lawfulness of the NLM photocopying program. ${ }^{334}$ Consequently, libraries that rely on the CONTU Guidelines are not only implementing guidelines that have the support of a congressionally established commission, but guidelines that have in large substance been the subject of - or at least have emerged from - judicial analysis. Those circumstance alone give the CONTU Guidelines greater authority and greater legal credibility than any of the other guidelines examined in this article.

Although the Williams \& Wilkins case may give the CONTU guidelines important support, the case has been frequently criticized. Nimmer joins a list of copyright experts who have been highly critical of the Williams \& Wilkins ruling: "This landmark decision by the Court of Claims appears to this writer to be seriously in error, with implications that might well justify its description by one of the dissenting judges as "the Dred Scott decision of copyright law." 335 A comparison of fair use to slavery may be hyperbole, but the depth of the criticism is clear. Nimmer disassembles the internal logic of the ruling, and he argues that the case is inconsistent with fundamental precepts of fair use. ${ }^{336}$ The questionable survival of Williams \& Wilkins in future court decisions elevates the importance

328 Id.

329 Cf. Sony Corp. of Am. v. Universal City Studios, Inc., 464 U.S. 417, 449-50 (1984)

(finding fair use despite reproduction of the entire work). See also supra note 300.

330 Williams \& Wilkins, 487 F.2d at 1356-57.

331 Id. at 1363.

332 Pub. L. No. 94-553 (1976), 90 Stat. 2546 (codified as amended at 17 U.S.C. § 108

(1994 \& Supp. IV 1998)).

333 See 17 U.S.C. $\S 108(\mathrm{~g})(2)(1994)$.

334487 F.2d at 1354.

3354 NIMMER ON COPYRIGHT, supra note 7, § 13.05[E][4][c] (footnote omitted). 336 Id. 
of the passage of section $108(\mathrm{~g})(2)$ to secure limited rights of copying for interlibrary loans, notwithstanding variable interpretations of fair use.

The CONTU Guidelines further reinforce that lawful opportunity. This transition from the uncertainty and controversy of fair use to reliance on section 108 is a manifestation of the importance that Congress places on the survival of interlibrary services and the copying that makes the service and the preservation of collections possible. Even if Nimmer is correct about traditional fair-use principles when, for example, he criticizes the decision for placing too much emphasis on the interest of "medicine and medical research" in general,,337 Congress may well have overridden that concern by passing section 108 of the Copyright Act. Section 108 and the CONTU Guidelines may not be wholly consistent with fair use, but that conclusion may not be relevant to the merits of current law for interlibrary services; that law is now rooted in broader principles of the need for expanding access to materials at remote locations, on urgent request, and under other circumstances that advance interests of learning and expanding knowledge in general.

\section{Glimpses from the U.S. Supreme Court}

Two decisions from the U.S. Supreme Court provide some brief indications of the Justices' thinking on this matter. In the well-known 1984 decision, Sony Corporation of America v. Universal City Studios, Inc., the Court ruled narrowly that taping a broadcast television program off the air for later private viewing was fair use. ${ }^{338}$ Four Justices dissented, arguing that fair use does not necessarily allow the making of complete copies of works, even for private use. ${ }^{339}$ The dissenters noted, for example, that section 107 of the Copyright Act allows full copies under certain circumstances ${ }^{340}$ :

In other respects, the making of single copies is permissible only within the limited confines of the fair use doctrine. The Senate report [accompanying passage of the 1976 Act], in a section headed "Single and multiple copying," notes that the fair use

337 See id. § 13[E][4][c].

338464 U.S. 417, 455 (1984).

339 Id. at 457-500 (Blackmun, J., dissenting).

$340 \mathrm{Id}$. at $464-65$. The dissenters noted further that full copies may be allowed under section 112 (broadcasters may make one copy of transmissions) or copies for blind persons or copies made by student calligraphers for leaming purposes (then solely a matter of fair use, but today some such copies are allowed under section 121). The list is a peculiar hallmark of the issues of that time. Id. at $464-65 \mathrm{nn} .11 \& 12$. 
doctrine would permit a teacher to make a single copy of a work for use in the classroom, but only if the work was not a "sizable" one such as a novel or treatise. ${ }^{341}$

The dissenters made a detailed survey of fair use, with numerous references to hearings, reports, and other pieces of the legislative history of the Copyright Act, but the opinion, curiously, never alludes to the Classroom Guidelines. ${ }^{342}$ The Court did not need to make those references, but the opinion seems to touch every other relevant issue surrounding the guidelines, including the quotation above about copies for teaching. Evidently, the Court was avoiding the repercussions of making any statement about the guidelines in a case where such statements would be unnecessary and likely inflammatory in the aftermath of a closely divided decision of importance to the millions of Americans who watch television.

The Sony dissent also examines off-air videotaping in the legislative history of the fair-use statute. ${ }^{343} \mathrm{In}$ a brief examination of off-air videotaping for educational uses, the Court did not look to the guidelines, ${ }^{344}$ but it instead referred to the committee reports from the passage of the 1976 Act to conclude: "Even in the context of highly productive educational uses, Congress has avoided this temptation [to 'stretch' fair use for new technologies]; in passing the 1976 Act, Congress made it clear that off-the-air videotaping was to be permitted only in very limited situations." 345 This heavy emphasis on the legislative history, with scrupulous avoidance of the guidelines themselves, is consistent with the dissenters' discussion of photocopies for education: considerable detail from the reports and hearings, but no mention of the guidelines. ${ }^{346}$ Inferences from omissions are hazardous, at best. Yet, amidst detailed examination of the legislative history, the omission of any mention of the guidelines begs questions about their significance as a gauge of the law or even of congressional intent.

The following year, in 1985, the Court ruled in Harper \& Row, Publishers, Inc. v. Nation Enterprises ${ }^{347}$ that a magazine exceeded the limits of fair use when it made brief quotations . from President Gerald Ford's then unpublished

${ }^{341} \mathrm{Id}$. at 465 . The dissenters proceeded to cite S. REP. No. 94-473, at 63-64 (1975) and H.R. REP. No. 94-1476, at 68-69, 71 (1976).

342 Sony, 464 U.S. at $475-86$.

343 Id. at $480-81$.

344 See Off-Air Guidelines, supra note 4.

345 Sony, 464 U.S. at 481. The opinion cites H. R. REP. No. 94-1476, at 71 (1976), and S. REP. No. 94-473, at 64 (1975).

346 The Off-Air Guidelines may be distinguished in this context from the Classroom Guidelines, because the former did not exist until 1981 and thus were not truly evidence of congressional intent supporting passage of the 1976 Act. Yet the dissenting opinion in Sony mentions neither set of guidelines, even the Classroom Guidelines as they appeared in the H.R. REP. No. 94-1476, at 68-70 (1976). See Sony v. Universal City Studios, Inc. 464 U.S. 417, 476 (1984) (Blackmun, J., dissenting).

347471 U.S. 539 (1985). 
memoirs. ${ }^{348}$ The Court drew some of its fair-use analysis from the legislative history of the 1976 Act, noting that the Senate Report "selected photocopying of classroom materials to illustrate fair use." 349 In the process, the Court lent some credibility to the Classroom Guidelines. The Senate Report includes some analysis of classroom photocopying, but that language was omitted from the subsequent House Report. The Court did not view the omission as a retraction of principles in the Senate Report, but instead the Court made this explanation:

It appears instead that the fair use discussion of photocopying of classroom materials was omitted from the final [House] Report because educators and publishers in the interim had negotiated a set of guidelines that rendered the discussion obsolete. The House Report nevertheless incorporates the discussion by reference, citing to the Senate Report and stating: "the Committee has reviewed this discussion, and considers it still has value as an analysis of various aspects of the [fair use] problem."350

This approach is little more than a recognition that the Classroom Guidelines exist, without offering them any support or criticism. The Court did not need to give them any substantive look. The issue of classroom copying was not at issue in this case, and the discussion of classroom copying was only a model for understanding fair use in general. If anything, the Court's passing mention of classroom copying and the guidelines is a reminder that the Court will look primarily to general principles of fair use in its quest to resolve an issue before it, but guidelines continue to surface in the quest for fair use. ${ }^{351}$

348 Id. at 569.

$349 \mathrm{Id}$. at 553 .

350 Id. at 554 (citations omitted).

351 The U.S. Supreme Court has not addressed directly the issues surrounding photocopying for teaching or research purposes. The Sony and Harper \& Row cases are the Court's only mentions of the Classroom Guidelines. In 1994 one more passing mention of classroom photocopying was buried in Campbell v. Acuff-Rose Music, Inc., 510 U.S. 569 (1994), the well-known decision involving the rap-parody version of Roy Orbison's song "Oh, Pretty Woman." The "purpose" factor under section 107 may weigh in favor of fair use under various circumstances, including if the use is "transformative." Id. at 579 n.11. Transformative use was a critical part of the analysis in a case involving a significant variation on an existing song. Transformative use usually does not occur in a case of simple photocopying. At least two cases have found straight photocopying to be non-transformative and therefore the purpose factor weighed against fair use. See Princeton Univ. Press v. Mich. Document Servs., Inc., 99 F.3d 1381 (6th Cir. 1996); Am. Geophysical Union v. Texaco Inc., 60 F.3d 913 (2d Cir. 1994). Yet in a passing mention in the Campbell decision the U.S. Supreme Court made this strong statement about fair use and classroom copying: "the obvious statutory exception to this focus on transformative uses is the straight reproduction of multiple copies for classroom distribution." Campbell, 510 U.S. at 579 n.11. The source of this conclusion is the language of section 107 itself, which, in listing the types of activities to which fair use may apply, mentions "teaching," followed by this parenthetical statement: "including multiple copies for classroom 


\section{E. Synthesis of the Cases}

In almost twenty-five years of fair-use guidelines, only a few court rulings have been relevant to the intended applications of the guidelines. None of the principal cases is actually within the scope of the guidelines; none involves copies made for nonprofit educational purposes. The courts have stretched application of the guidelines not to find a foundation for a ruling, but instead to reinforce a ruling already reached. However, outside the scope of these few cases where the courts were willing to stretch guidelines to copying for profit, whether conducted by a researcher or by Kinko's, most courts have not been willing to make similar leaps. 352

Applying the guidelines in any case beyond the literal situations they encompass is a risky proposition for all interested parties. Imagine either of two situations. First, suppose the court in Texaco had applied the four factors and concluded, as it did, that the copying was not fair use. ${ }^{353}$ Then the court looked to the Classroom Guidelines, and by analogy to single copies of articles for teaching and research, concluded that the copying taking place inside Texaco Inc. was within the "spirit" of the guidelines and hence perhaps within fair use after all. Under this proposition, the conflict between law and guidelines would be overt, and the publishers in the Texaco case would ultimately be arguing for a reading of fair use that conflicts with the court's understanding of guidelines that the publishers has supported for many years.

The second situation is the reverse. Imagine that the Texaco court ruled that the copying was within fair use, after applying the statutory factors. Then it looked to the guidelines and resolved that the for-profit activity was clearly not within the guidelines, and that application of the guidelines was "compelling."354

use." 17 U.S.C. $\S 107$ (1994). The Court's recognition of the importance of this provision is well deserved. The clause was a late addition to the language of section 107 shortly before passage of the Copyright Act in 1976, and its addition to the pending bill was a careful and deliberate step to articulate the intent of Congress that straight copying was within the congressional understanding of fair use. This conclusion is hardly an open door for all classroom copying to be fair use, but it is an indication that classroom copying is generally favored under the law and need not be subject to a test of "transformative" use. This broad acknowledgement of allowing direct copies suggests that rigorous conditions on portion limits and restrictions in the guidelines may be in disregard of the special deference Congress gave to education when exercising fair use.

352 For example, in Texaco, 60 F.3d at 915 , the Second Circuit ruled that single copies of articles for research are not fair use. Although these basic facts are similar to some conditions outlined in the Classroom Guidelines, the facts were also critically different. The research was in the context of a for-profit entity, and the copies were not made for private research or for teaching preparation. See also supra Part III.A.4.

353 See Texaco, 60 F.3d at 932.

354 The Kinko's decision found application of the Classroom Guidelines was "compelling." See supra text accompanying notes 231. 
Again, the court would have found a conflict between its reading of the law and its application of the guidelines.

Either of these situations creates a direct conflict between law and guidelines. How might the court respond to that conflict? Clearly the court should respond by giving the law precedence over the guidelines. But perhaps the prospect of such an awkward conflict reveals the limited significance of the courts' utilization of the guidelines in actual cases; the guidelines were raised only to affirm a decision already rendered. The guidelines were not even part of a fresh perspective on the legalities of fair use. They were not even truly given a separate analysis. They were reinforcement to give the ruling a slightly stronger foundation and to give the judges a slightly stronger sense of having reached a correct conclusion. The guidelines simply would not have been deployed by the court had they stirred a contradictory result and posed yet a further challenge for a judge needing to make practical sense of fair use. These succinct hypothetical situations, reinforced by the way guidelines are used in actual court cases, demonstrate that the guidelines ultimately have not been adopted as a legal foundation for fair use, but rather are a tool of convenience to achieve a desired result.

What then is the real meaning of the Classroom Guidelines as revealed in these cases? On the one hand, if the guidelines are useful tools for judges and other arbiters of fair-use controversies, then they are still only a tool for bolstering a decision already made after applying the four factors of section 107 to the facts of the case. For educators and others who need to live by some measure of fair use for routine classroom copying, the cases manifest some definite lessons about the weaknesses of the guidelines. They are not the law. They may even contradict the law in past and future cases. For all practical purposes, courts may view them as a "safe harbor," but even many of the most vigorous supporters will not give them that level of credibility. ${ }^{355}$ On the other hand, if the courts look to them as crutches, in roughly analogous cases, one can be certain that a court will look to the guidelines in a case against an educator or educational institution-the situations where the guidelines are intended to apply. Yet the cases from the past also suggest that the court will most certainly look to the guidelines only after applying the four factors. Thus, even when guidelines are available for a specific application, educators would be remiss to rely on them without applying the four factors that actually form the foundation of fair-use law.

\section{CONFLICTING PERCEPTIONS OF FAIR-USE GUIDELINES}

Building upon the preceding foundation of legal analysis, this Part IV of the article will test the validity of various perceptions and characterizations attributed to the guidelines. Those characterizations will be grouped in classifications that reflect the broader impressions that guidelines have made on the community

355 See infra Part IV.A.2. 
working with fair use. Some examinations lead to the conclusion that guidelines are a measure of fair-use law. Other reviews have given them weight as legislative history, perhaps revealing congressional intent about the meaning of fair use. Still other characterizations see the guidelines as private tools for applying fair-use principles only to the parties that assent, or as evidence of acceptable or tolerable behavior.

This scrutiny of the guidelines will reject the validity of most common perceptions of the guidelines. Part V of this article will offer to replace those faulty characterizations with a fresh comprehension that reflects more accurately the legal status of the guidelines.

\section{A. Guidelines and the Law}

\section{Guidelines as a Measure of Fair Use}

All of the guidelines fail any valid claim that they might have binding, legal authority. ${ }^{356}$ Congress never enacted them. ${ }^{357}$ No court ever has read them into law in a legal decision. ${ }^{358}$ From a source-based analysis, one can unequivocally conclude that the guidelines are not themselves binding on the public as a rule of law. 359 That conclusion, however, begs the remaining question: could the guidelines still be an accurate statement of fair-use law, even though they have not been specifically adopted by a lawmaking authority? Just because the courts have not adopted the guidelines does not necessarily mean that they do not embody an accurate measure of fair use for the limited situations they describe. No court has had such a case for actually testing the guidelines.

Indeed, the circumstances in the cases examined in this article have departed greatly from the limits of the guidelines. According to the $M D S$ decision, for example, the use was "light years beyond" the limits of fair use articulated in the Classroom Guidelines. 360 Without a court ruling on facts resembling the guidelines, the outcome of such a decision is somewhat, although not entirely, speculative. Some suggestions of such a ruling appear in a few of the existing cases. The Kinko's case, for example, made a fairly meticulous review of the

356 See, e.g., Jonathan Zavin, Copyright Infringement Litigation, 567 PLI/PAT 327, 331 (July-Aug. 1999) (arguing that Classroom Guidelines lack the force of law).

357 The guidelines that have been presented to Congress have received only positive comments in reports, but never have they been carried any further toward legislation. For discussion of such treatment of the guidelines, see infra Part IV.A.4.

358 For discussion of the treatment of the guidelines in court rulings, see supra Part III.

359 Part V of this article will examine the "pedigree" of the guidelines with respect to the authority of their sources and their relationship to positive law.

360 Princeton Univ. Press v. Mich. Document Servs., Inc., 99 F.3d 1381, 1390-91 (6th Cir. 1996). 
guidelines, ${ }^{361}$ and the court ultimately rejected urgings by the publishers to endorse one important prohibition in the Classroom Guidelines. 362 Thus, the court found that the Classroom Guidelines were, at least in that one important respect, not consistent with fair use and were instead more restrictive than the law actually allowed. ${ }^{363}$ Even a for-profit copyshop, where fair use is relatively narrow, was not held to the full sweep of restrictions in the guidelines. If the guidelines were an attempt to express the actual law of fair use, they failed in at least one critical respect that was of tremendous importance to the plaintiffs.

Language directly from other court opinions further affirms that the guidelines are not likely to be accepted as a statement of law. Typical of a court's view of the Classroom Guidelines is this statement from Marcus v. Rowley: "Thus, while they are not controlling on the court, they are instructive on the issue of fair use in the context of this case." 364

Guidelines are far from law in many other respects, both substantively and structurally. The Classroom Guidelines are again the most salient case on point. They seek to quantify a law that Congress took pains to keep flexible. 365 They also introduce variables in the fair-use equation that appear nowhere in the statute. ${ }^{366}$ Specifically, fair use under the statute depends on the four factors of purpose, nature, amount, and effect. ${ }^{367}$ The guidelines, however, make fair use dependent on brevity, spontaneity, and cumulative effect. ${ }^{368}$ By focusing on those variables, rather than the statutory four factors, guidelines depart abruptly from the law itself and may in fact make decisions based upon standards that are legally less sound. To the extent that the variables from the Classroom Guidelines have recast conceptualizations and articulations of fair use, the guidelines may be a subversive force on the law, as they purport to displace the congressionally sanctioned factors with a privately negotiated alternative. 369

361 Basic Books, Inc. v. Kinko's Graphics Corp., 758 F. Supp. 1522, 1535-37 (S.D.N.Y. 1991).

362 See supra text accompanying notes 234-39.

363 See supra text accompanying note 238.

364695 F.2d 1171, 1178 (9th Cir. 1983).

365 H.R. REP. No. 94-1476, at 68-70 (1976).

${ }^{366} I d$. at 68-69, 71 (1976).

367 See supra text accompanying notes $21-24$.

368 See supra text accompanying notes 70-73.

369 Not only do the Classroom Guidelines replace legal factors with negotiated factors, but the guidelines also replace the balancing test of fair use with a requirement that users satisfy all of the factors in the guidelines. See Wagner, supra note 236, at 11 ("All four tests [brevity, spontaneity, cumulative effect, and inclusion of notice] must be satisfied to provide Fair Use protection for multiple copying."). 
One of the most salient examples of such variation from the law is "spontaneity." 370 The Classroom Guidelines introduced this concept, explaining that copying must be "at the instance and inspiration of the individual teacher," and that the decision to use the work must be "so close in time" to the "moment of its use" that permission is not likely to be obtainable. ${ }^{371}$ This type of "spontaneity" may be evidence that the copying is for educational purposes, consistent with the "purpose" factor of the statute. 372 Spontaneity may also be evidence that the ability to seek and secure permission is not practical, so a charge for fees is also unlikely. Such circumstance may evidence that the copying has little adverse market effect, consistent with the last factor under the fair-use statute. To that extent, the guidelines may offer one possible means toward satisfying the law. But in this context, the guidelines are vastly overreaching. First, they tend to freeze the means for satisfying the fair-use statute, when multitudes of possibilities for defining fair use ought to have the same credibility as any other possibility. ${ }^{373}$ Second, they give the impression that "spontaneity" and other concepts really are part of fair use. That misperception has been prevalent in many of the CONFU meetings, where participants often demanded that statements of fair use include a "spontaneity" requirement. Spontaneity may well be evidence relevant to some of the fair-use factors, but it is hardly required. The guidelines have been construed as if to require it.

Another prominent conflict between the guidelines and the law is with respect to the "amount" factor. The amount allowed under many of the guidelines is both rigid and minuscule. ${ }^{374}$ Perhaps the narrowest quantum of copying in any case that identified an infringement was in the Harper \& Row v. Nation Enters. decision from the United States Supreme Court in 1985, holding that a quotation of only about three hundred words in a publication was an infringement. ${ }^{375}$

${ }^{370}$ Scott M. Martin, Photocopying and the Doctrine of Fair Use: The Duplication of Error, 39 J. COPYRIGHT SOC'Y U.S.A. 345, 386 (1992).

371 According to the Classroom Guidelines: "The copying is at the instance and inspiration of the individual teacher," and "[ $[t]$ he inspiration and decision to use the work and the moment of its use for maximum teaching effectiveness are so close in time that it would be unreasonable to expect a timely reply to a request for permission." See Classroom Guidelines, supra note 4 , at 69.

372 At least one case has used "spontaneity" in this context. See Am. Geophysical Union v. Texaco Inc., 60 F.3d 913, 919 (2d Cir. 1994).

373 The Classroom Guidelines first appeared in the House Report from 1976, and they directly contradicted statements in that report against "freezing" fair use. H.R. REP. NO. 94 1476, at 66 (1976) ("There is no disposition to freeze the doctrine in the statute, especially during a period of rapid technological change.").

${ }^{374}$ L. Ray Patterson, Regents Guide to Understanding Copyright and Educational Fair Use, 5 J. INTELL. PROP. L. 243, 283 (1997) ("Quantifying fair use is contrary to the statutory right of fair use, which authorizes the user to exercise his or her judgment in accordance with the provisions of section 107.").

375471 U.S. 539, 565 n.8, 569 (1985). 
Although that case dealt with reproduction and publication of the materials, the exceedingly brief excerpt was within the tight parameters of "brevity" laid out in the Classroom Guidelines. ${ }^{376}$ On the other hand, Harper \& Row also involved the surreptitious taking and use of an unpublished manuscript and knowingly jeopardizing sales of the work once published-facts that also militated against a finding of fair use. ${ }^{377}$

By contrast, when the facts involve earnest and good-faith uses of published works, in ways that do not likely harm significant sales - as would often be the situation with common copies for classroom distribution-the outcome in a court case is likely to be completely different. Such was the case of Maxtone-Graham v. Burtchaell, ${ }^{378}$ in which the Second Circuit Court of Appeals upheld the use of extensive excerpts from one book into a later publication. There the court ruled that copying as much as seven thousand words was fair use. ${ }^{379}$ The cap of one thousand words under the "brevity" element of the Classroom Guidelines seems paltry by comparison.

Despite the many problems with the Classroom Guidelines in particular, they have had an irresistible appeal for many people who perhaps ought to know better. The judge in the Kinko's case, for example, called application of the guidelines in that case "compelling," 380 despite their inapplicability to for-profit copying 381 and despite finding that the guidelines are not entirely a good summary of the law. 382 Even a prominent copyright treatise, Nimmer on Copyright, makes what might be best called an overreaching conclusion about the Classroom Guidelines. Nimmer correctly emphasizes that the guidelines "purport to state merely the minimum extent of fair use in connection with teacher photocopying." 383 Nimmer also adds that the guidelines are not controlling on a court, citing language from Marcus $v$. Rowley. ${ }^{384}$ Yet in an odd twist, Nimmer underscores that the House Report containing the original guidelines ${ }^{385}$ does not control the definition of fair use, but he concludes that the guidelines are practically the embodiment of law:

376 Classroom Guidelines, supra note 4, at 68 (allowing, for example, an instructor to photocopy for distribution up to one thousand words from an article).

377 Harper \& Row, 471 U.S. at 562-63.

378803 F.2d 1253, 1265 (2d Cir. 1986).

379 Id. at $1257,1263$.

380 Basic Books, Inc. v. Kinko's Graphics Corp., 758 F. Supp. 1522, 1536 n.11 (S.D.N.Y. 1991).

381 Id. at $1535-36$.

382 See supra text accompanying notes 234-39.

3834 NMMER ON COPYRIGHT, supra note 7, § 13.05[E][3][a].

384 Id.; Marcus v. Rowley, 695 F.2d 1171, 1178 (9th Cir. 1983).

385 H.R. REP. No. 94-1476, at 66-71 (1976). 
Strictly speaking, the guidelines represent merely the Congressional Committees' "understanding" of what the courts would regard as fair use in applying the traditional judicial doctrine of fair use. Congress does not purport to substitute its judgment for that of the courts in any particular case. Nevertheless, it seems clear that the courts will be greatly influenced by this "understanding," so that for practical purposes the guidelines may usually be regarded as the equivalent of statutory text. 386

Nimmer builds his case on matters of no precedential value, and which involve no judicial decision: the 1983 settlement of the lawsuit against New York University ${ }^{387}$ and an opinion of the Attorney General of Kansas. ${ }^{388}$ Nimmer also depends heavily on Marcus $v$. Rowley, ${ }^{389}$ but that court carefully avoided reading the guidelines into the law. ${ }^{390}$ The Kinko's court may have reflected common sentiment when it called the Classroom Guidelines "compelling,"391 but Nimmer is without justification when he equates them with statutory status.

\section{Guidelines as a Minimum Scope of Fair Use-the "Safe Harbor"}

The original language from the Classroom Guidelines and the Music Guidelines began the notion that guidelines are an expression of "minimum" concepts of fair use. .92 By their own terms those guidelines "state the minimum and not the maximum standards of educational fair use under section 107.393 The Court of Appeals in Marcus $v$. Rowley accordingly declared: "The guidelines were intended to represent minimum standards of fair use."394 The Uniform Preamble of the CONFU guidelines carries a similar message in considerably different terms: "Uses that exceed these guidelines may or may not be fair use. The endorsers also agree that the more one exceeds these guidelines, the greater

3864 NIMMER ON COPYRIGHT, supra note 7, § 13.05[E][3][a] (footnotes omitted). Another major treatise on copyright law takes a comparatively subdued and objective approach to the Classroom Guidelines: "The guidelines, which do not have the controlling force of law, aim to create a safe harbor for classroom photocopying." 2 PAUL GOLDSTEN, COPYRIGHT $\S 10.2 .2 .1$ (2d ed. 1996 \& Supp. 1998).

387 For discussion of the NYU case, see supra Part III.A.1.

388 Op. Att'y Gen. Kan., 1981 COPYRIGHT L. DEC. (CCH) ף 25,331 (1981).

389695 F.2d at $1178-79$.

390 For discussion of the Marcus case and its use of the guidelines, see supra Part III.A.5s 274-86.

391 Basic Books, Inc. v. Kinko's Graphics Corp., 758 F. Supp. 1522, 1536 n.11 (S.D.N.Y. 1991).

392 David J. Bianchi et al., Comment, Basic Books, Inc. v. Kinko's Graphics Corp.: Potential Liability for Classroom Anthologies, 18 J.C. \& U.L. 595, 606 (1992). 68.

393 Music Guidelines, supra note 4, at 71; see, e.g., Classroom Guidelines, supra note 4, at

394695 F.2d at 1178. 
the risk that fair use does not apply." 395 While this language does not explicitly describe the guidelines as "minimum" standards, the implication that they represent some version of a minimalist interpretation is clear. The CONFU preamble does make explicit that something beyond the limits of the guidelines may still be fair use. 396

Another articulation of a "minimal" concept of the guidelines is the appellation "safe harbor." The Sixth Circuit Court of Appeals called the Classroom Guidelines a "safe harbor" in the $M D S$ case. ${ }^{397}$ The district court in Kinko's also referred to them as a "safe harbor,"398 but equivocated. That court seemed to reserve the possibility that copying beyond the guidelines may be fair use, but copying within them may also be infringement: "courts must balance the interests involved."399

The label "safe harbor" was an object of steady attention and diligent rejection in the CONFU negotiations. ${ }^{400}$ Many participants were accustomed to calling the earlier guidelines a "safe harbor," and they saw in the language of the CONFU preamble and in the nature of the discussions that the next generation of guidelines would also take the same construct. The guidelines would be a minimal measure of fair use, where one would most assuredly be free from infringement risks. Additional fair use would be possible, but with no assurance of protection from liability. Many representatives of the commercial publishing industry eschewed that vision. They sought instead to preserve the right to bring an infringement action against uses that are within the guidelines, however remote the desirability of such an action may be.

The purported "final" meeting of CONFU, on May 19, 1997, brought the beginning of change and some crucial reinforcement of the "safe harbor" concept for guidelines. ${ }^{401}$ Representatives of the Association of American Publishers (AAP) and Broadcast Music, Inc., announced in the open meeting that they would regard the Multimedia Guidelines to be a safe harbor, and that they would not bring a lawsuit against nonprofit educational institutions that remain within the

395 CONFU FNAL REPORT, supra note 4, at 31.

396 This particular clause in the preamble has been a point of serious contention among CONFU participants. Some negotiators have understood it as a generous expression of openness to possible fair use beyond the defined limits of the guidelines. Other negotiators have seen the language as an anchor on the flexibility of fair use, constantly pulling one back to the gravitational center of the stated limits of the guidelines.

397 Princeton Univ. Press v. Mich. Document Servs., Inc., 99 F.3d 1381, 1391 (6th Cir. 1996).

398 Basic Books, Inc. v. Kinko's Graphics Corp., 758 F. Supp. 1522, 1537 (S.D.N.Y. 1991).

' 399 Id. at 1536 (citing 4 NIMMER ON COPYRIGHT, supra note 7, at § 13.05[E], at 13-96).

400 These observations from CONFU meetings are from the author's personal participation in the discussions.

401 Id. 
guidelines. Their change of position was an important development, but it did not achieve full assurance. The Authors League of America responded that it was not prepared to give up the right to bring an action against even "minimal" activities. The League's representative pointedly called the guidelines, at best, a "safer harbor." 402

The guidelines may ultimately fail to pass complete scrutiny as "minimal" standards or as a safe harbor. ${ }^{403}$ Until the prospective plaintiffs-particularly the commercial publishers and authors-unequivocally give the guidelines an identity as a zone of safety, the guidelines may never attain the degree of assurance necessary to attract broad-based consensus for the standards. The AAP and others undoubtedly changed their position and declared the Multimedia Guidelines to be a "safe harbor" in order to attract added support for the guidelines, especially from educators who may be looking for sure protection from liability.

Theoretically, a court could read a set of guidelines into the law of fair use and declare them to be a zone of safety, or Congress could stake out a similar position by statute. But the courts and Congress have avoided exactly those possibilities. The notion of a safe harbor may have some intuitive appeal, but it could have important detrimental consequences. A "safe harbor" would be a major step toward freezing fair use and undermining its flexibility. ${ }^{404}$ In the end, the concept of safe harbor may be established only by the private parties who give the guidelines their shape and existence in the first.place. Without near unanimity among the publishers, authors, and other copyright owners, the concept of a truly safe harbor for any set of guidelines is fatally flawed. As long as the right to sue or even threaten to sue a party remains, the harbor has rough water and mines.

\section{Guidelines as a Maximum Scope of Fair Use}

To call the guidelines a "maximum" measure of fair use may defy logic and contradict the language of "minimum" standards. ${ }^{405}$ Indeed, rational arguments and plain statements from the text of the guidelines and some relevant cases point to conceptualizing the guidelines as minimum standards, ${ }^{406}$ or even perhaps a

402 Id.

403 Nevertheless, the perception of a "safe harbor" persists with some inference of its benefits. See Salomon \& Pierce, supra note 64 , at 325 ("These understandings between educators and copyright owners have served as 'safe harbor' standards for fair use and have, to some degree, reduced uncertainty and transaction costs for educators.").

404 Contra H.R. REP. No. 94-1476, at 66 (1976) (stating, "there is no disposition to freeze the doctrine in the statute, especially during a period of rapid technological change").

405 Klingsporn, supra note 1 , at 108 (noting that universities adopt the guidelines as maximum standards).

406 See supra Part IV.A.2. 
definition of fair use itself.407 Yet some suggestion of "maximum" limits surround the guidelines. ${ }^{408}$

The most prominent example of a maximum standard is the use of the Classroom Guidelines in the settlement of the New York University case. ${ }^{409}$ There the settlement required faculty members and others at NYU to seek advice of university counsel before exceeding the guidelines. ${ }^{410}$ As a practical matter, that advice is not readily forthcoming, and the guidelines consequently become the limit of fair use for classroom photocopying. Moreover, the wording of the settlement agreement and the consequent policy statement for the NYU community was built on the Classroom Guidelines, but omitting the prefatory paragraph assuring that the guidelines are "the minimum and not the maximum standards" of fair use. 411 By their plain language and their practical effect, the NYU settlement made maximums of minimums. 412

Further, the guidelines themselves may include language of "minimum" standards, but they also include some overt maximum standards. The inclusion of "prohibitions" in the Classroom Guidelines, and similar outer boundaries in the Multimedia Guidelines, is an attempt to establish caps on fair use. One such prohibition-regarding the making of anthologies-was asserted against the defendant in the Kinko's decision. ${ }^{413}$ The plaintiffs urged the court to adopt a sweeping prohibition against all coursepacks, in accord with the prohibition from

407 See supra Part IV.A.1.

408 See Edward Samuels, The Public Domain in Copyright Law, 41 J. COPYRIGHT SOC'Y U.S.A. 137, 142 n.26 (1993) (expressing concem over mischaracterizations of the guidelines as maximum standards).

409 See supra Part III.A.1.

410 Jane C. Ginsburg, Reproduction of Protected Works for University Research or Teaching, 39 J. COPYRIGHT SOC'Y U.S.A. 181, 202 (1992).

411 The Uniform Preamble to the CONFU Guidelines, CONFU FINAL REPORT, supra note 4, at 31-32, includes this statement: "This Preamble is an integral part of these guidelines and should be included whenever the guidelines are reprinted or adopted by organizations and educational institutions." Inclusion of that statement is a direct result of the experience of the NYU case and the stripping off of the prefatory paragraph that put the guidelines in an important context. The author of this article is hardly a supporter of the CONFU Guidelines, but he is the author of that one sentence and pressed the CONFU negotiators to include it in order to prevent a repeat of the NYU experience with parties under pressure accepting bowdlerized versions of the guidelines, if they choose to accept them at all. For a discussion of the NYU case and the use of guidelines in the settlement, see supra Part III.A.1.

412'Some educators and librarians fear that one particular statement in the Uniform Preamble of the CONFU Guidelines will have an effect of drawing any innovations in fair use back to the limits of the guidelines, thus making effective maximums of the CONFU Guidelines by putting an onerous burden on users to justify their activities in light of the four factors of fair use and from a frame of reference of the guidelines.

413 See supra text accompanying notes 234-39. 
the Classroom Guidelines. The court refused to accept it. 414 The court, in fact, rejected that prohibition, signaling an unwillingness to view even a narrow aspect of the guidelines as a mandate. In sum, the Classroom Guidelines may have been adopted as a maximum in the NYU settlement, and some of the guidelines may include attempts to limit fair use, but no court has accepted those boundaries. ${ }^{415}$

\section{Guidelines as Legislative History}

The appearance of some guidelines in congressional reports, and even in a "nonlegislative" report, ${ }^{416}$ has been cited as a source of authority for the standards. Positive congressional action may well have considerable influence on the decisionmaker seeking to identify and apply a standard when faced with a fair-use problem. But appearance in legislative history obviously does not give the guidelines the force of law, and may not even give them much credibility in the interpretation of fair use under current doctrine. Legislative history, quite simply, is no longer given the strong weight it may once have held in statutory interpretation. 417

Not only might legislative history play a diminishing role in current legal doctrine, but a closer look at the legislative history regarding fair use suggests that Congress may have been applauding the process of guideline development as much as the content of the finished work. ${ }^{418}$ To the extent that Congress offered compliments, it seemed as pleased with a resolution and a cooperative process as much as with the substantive outcome. At no time did Congress scrutinize or

414 Basic Books, Inc. v. Kinko's Graphics Corp., 758 F. Supp. 1522, 1543 (S.D.N.Y. 1991) ("The fact that Congress has set forth a statement in its Classroom Guidelines that anthologizing is prohibited does not require this court to paint with the broad brush plaintiffs suggest.').

415 Yet the perception of the guidelines as the limits of fair use continues. See Robert Kasunic, Fair Use and the Educator's Right to Photocopy Copyrighted Material for Classroom Use, 19 J.C. \& U.L. 271, 289 (1993) (finding that the Classroom Guidelines "have the potential for obstructing the fair-use analysis by creating a perception that anything outside the Guidelines is unfair").

${ }^{416}$ The Multimedia Guidelines were the subject of a "nonlegislative report" from a congressional committee. See supra text accompanying note 215-16.

417 See generally Michael H. Koby, The Supreme Court's Declining Reliance on Legislative History: The Impact of Justice Scalia's Critique, 36 HARV. J. ON LEGIS. 369 (1999); Jane S. Schacter, The Confounding Common Law Originalism in Recent Supreme Court Statutory Interpretation: Implications for the Legislative History Debate and Beyond, 51 STAN. L. REV. 1 (1998); Robert C. Vaughn, A Comparative Analysis of the Influence of Legislative History on Judicial Decision-Making and Legislation, 7 IND. INT'L \& COMP. L. REv. 1 (1996). The dissent in the MDS decision used this argument against the Classroom Guidelines. See supra text accompanying notes $259-65$.

418 See H.R. REP. No. 94-1476, at 72 (1976) ("The Committee appreciates and commends the efforts and the cooperative and reasonable spirit of the parties who achieved the agreed guidelines on books and periodicals and on music."). 
question the content of the guidelines. If the guidelines are to serve the needs of parties who agree to them, then Congress need not look closely at the terms. If the guidelines are to become a surrogate for law, then congressional examination would be helpful, if not essential. The lack of close examination of the guidelines' content suggests that Congress was endorsing the effort, not the substance. ${ }^{419}$

Nevertheless, some lingering references to the guidelines as legislative history appear in some cases. The Kinko's decision placed considerable weight on the fact that the Classroom Guidelines were a part of the legislative record. In dismissing general criticism of the guidelines as a "concession forced on educators," the court refused to dissect the processes leading to the guidelines and concluded that " $t]$ he congressional record must speak for itself." 420 Elevating the guidelines to the level of congressional recognition had the effect of undermining any effort to investigate the circumstances of their origins and the relative representation of the interests in the copyright debate, because: "This court is in no position to retrospectively evaluate the quality of debate and parsing of privileges and responsibilities during Congress' or these groups' deliberations." 421

Dissenters in the $M D S$ case, by contrast, attacked reliance on the guidelines as legislative history in support of fair-use interpretation. ${ }^{422}$ That opinion made ample use of recent decisions from the U.S. Supreme Court undercutting the value of legislative history for statutory interpretation and narrowing the circumstances under which courts ought to look to legislative history at all. ${ }^{423}$ Moreover, the majority opinion in $M D S$ acknowledged that Congress may well have intended to accept a changing scope of allowable copying in light of changing circumstances and technologies. Thus, the legislative history that captures the sentiment of Congress in 1976 may be inconsistent with the larger concept of a fluid and flexible fair use. With reliance on legislative history falling out of favor, and with the guidelines revealing little of Congress's substantive understanding of fair use, the persuasive authority of the various guidelines as an indication of congressional intent seems to be of little significance.

419 The most recent example is the "Nonlegislative Report" about the Multimedia Guidelines. The language of that short document borrows heavily from the text of the Uniform Preamble to the CONFU Guidelines. See CONFU FINAL REPORT, supra note 4, at 14 n.48, 3132. It ultimately provides only broad, general statements about fair use and the role of guidelines, then applauds the efforts of the negotiators to reach agreement.

${ }^{420}$ Basic Books, Inc. v. Kinko's Graphics Corp, 758 F. Supp. 1522, 1535 n.10 (S.D.N.Y. 1991).

421 Id.

422 Princeton Univ. Press v. Mich. Document Servs., Inc., 99 F.3d 1381, 1410-12 (6th

Cir. 1996) (Ryan, J., dissenting).

423 Id. at 1411. 


\section{Guidelines as an Instrument for Judicial Decisionmaking}

Anyone who has struggled with understanding the meaning of fair use in any situation can certainly sympathize with judges who face the same problem and must justify a conclusion in a published opinion. In retrospect, the Classroom Guidelines are relatively easy to apply post-hoc to facts that have already transpired, especially in a mechanical manner that overlooks their "minimal" character. Such is the way the guidelines are used in judicial rulings. Yet to apply them after the fact, especially if the court already has applied the statutory factors, the court avoids the struggle of faculty and others who must determine through foresight whether some planned activity will be fair use..$^{424}$

\section{B. Guidelines and Their Parties}

\section{Guidelines as Agreements Not to Sue}

Most of the discussion of possible characterizations of the fair-use guidelines portrays them in their relationship to society at large, or at least to the members of society who are affected by the relevant decisions surrounding fair use. But the guidelines may also be considered as instruments that define relationships among the parties themselves. In this regard, the guidelines may be viewed as private compacts that have some binding quality on the named supporters, and not on all educators or other vast groups.

The defendant in the $M D S$ case, for example, argued to the Sixth Circuit that the Classroom Guidelines are an agreement by the AAP on behalf of its members not to sue a nonprofit educational institution that remains within the stated standards. ${ }^{425}$ It may have been a self-serving description by a litigant seeking to

424 This article earlier makes the assertion that judges have used the guidelines as a crutch to support a decision that is based on the four factors of the law itself. See supra Part III.E.

425 Kenneth D. Crews, Princeton Univ. Press v. Michigan Document Servs., Inc.: Notes from rehearing en banc before the Sixth Circuit Court of Appeals (1996), at http://www. iupui.edu/ copyinfo/mdshrg.html. This description also begs questions about the ability of the AAP to act on behalf of its members. In all of the discussion of guidelines as "agreements," one must look critically at the scope of subject matter to which any party has the authority to reach agreement. In the case of the AAP, for example, it may or may not have authority to reach agreement binding on its members; agreements in the name of the organization may be binding only on the organization itself. On the other hand, an agreement by the AAP not to bring an infringement action is a significant step with considerable consequence for its members. Infringement litigation is expensive, but if well organized and strategically executed, the parties can gain the greatest influence from successful litigation. Moreover, strategic planning should help avoid initiating a lawsuit that has significant chance of not succeeding. To that end, the AAP has organized and supported the major recent litigation of relevance to this study, such as Princeton University Press v. Mich. Document Servs., Inc., 99 F.3d 1381 (6th Cir. 1996); American Geophysical Union v. Texaco Inc., 60 F.3d 913 (2d Cir. 1995); Basic Books, Inc v. 
avoid application of the guidelines and advance the chance of winning a case, but the description is rational and perhaps even apt. An agreement that a set of guidelines is a "minimum" standard of fair use is tantamount to an acknowledgement that an infringement lawsuit against activities within the standard will fail. That concession, however, is not the same as an agreement not to sue. One may still bring an infringement case, regardless of how feeble the chances of winning. To agree that the guidelines are minimal fair use is more akin to calling them a "safe harbor," which already has been shown as a problematic appellation. ${ }^{426}$ To call them agreements not to sue is to take the notion one step further and to say that the parties have given up their right to test whether activity within the guidelines may nevertheless be infringing. Nothing in the guidelines themselves suggests that the parties really have forgone their right to go to court. Given the strident avoidance of the "safe harbor" concept by some parties, 427 they would most certainly reject any suggestion that they have further given up their right to bring a case to court.

\section{Guidelines as Agreement among the Parties Regarding Fair Use}

An essential quality of the fair-use guidelines is that they have been offered as a standard that may be adopted and employed by limitless persons and organizations seeking to understand and apply fair use. They are not limited in their application only to the parties who state their acceptance or endorsement at the end of negotiations. ${ }^{428}$ The use of guidelines in litigation demonstrates that they are advocated as standards of general or universal applicability. Yet options for understanding and applying fair use do exist. One can turn to the factors in the statute and case analysis; less prominent interpretations of fair use are also available. ${ }^{429}$ Consequently, the guidelines may not have the universal applicability that they would appear to have. Thus, they may instead reflect a private understanding of fair use that is applicable only to the guidelines' endorsers.

Kinko's Graphics Corp., 758 F. Supp. 1522 (S.D.N.Y. 1991), and the New York University case. For further background about the earliest of these cases and events leading to them, see Crews, supra note 50, at 43-55. Thus, an agreement by the AAP not to sue may, for all practical purposes, be an agreement by most of its members also not to file the action.

426 See supra Part IV.A.2.

427 See supra text accompanying notes $400-402$.

428 Patterson, supra note 374, at 282 (commenting on the Classroom Guidelines: "Private agreements do not eviscerate constitutionally based rights granted by congressional statutes-at least for those who are not parties to the agreement').

${ }^{429}$ See, e.g., ALA MODEL POLICY, supra note 4. 
Of course, the parties would object strongly to this characterization..$^{430}$ First, it would confine the effectiveness of the guidelines to the specific parties. That the guidelines would have some purported consequences for others who were not parties to the negotiations or agreement is the essence of their perceived value. The negotiators, quite simply, sought to define fair use for the broader public. ${ }^{431}$ Second, this characterization might make the guidelines actually binding on the parties. The endorsing parties would probably want to avoid this result as well. Few copyright owners have been prepared to call the guidelines a "safe harbor." 432 Fewer still would likely concede the right to bring an action against a use within the guidelines. Similarly, few educators and librarians have been willing to accept the guidelines as the limit of fair use; fewer still would likely enter into a binding commitment to follow the guidelines.

This conception of guidelines also does not reflect the reality of the meeting of the minds among the parties. The parties agreed on their interpretation of fair use, and not on a licensing of rights. The distinction is critical. First, the parties who negotiate and sign their names to any of the guidelines are often not

430 At least one court apparently rejected such a characterization. In reacting to testimony from a copyright law professor, the Kinko's court made this observation:

There was testimony introduced at trial by Professor Peter Jaszi that the Guidelines was no compromise but in fact a concession forced on educators. This testimony was admitted but, for the reasons stated here, this court places limited reliance on it. This is a likely claim by any party to a compromise. A compromise is just that, one side gives up some of its demands in exchange for concessions of the other party. This court is in no position to retrospectively evaluate the quality of debate and parsing of privileges and responsibilities during Congress' or these groups' deliberations. The congressional record must speak for itself.

Basic Books, Inc. v. Kinko's Graphics Corp., 758 F. Supp. 1522, 1535 n.10 (S.D.N.Y. 1991).

431 The assertion that private negotiators could establish a standard of fair use for the broader public is perhaps pretentious, but essential if the guidelines are to have the influence that the negotiators intended. In retrospect, one may question the wisdom of that objective. Regardless of the intended or actual influence of the guidelines, the parties to them are the only ones who actually manifested their assent to the terms. Developers of the CONFU Guidelines even sought to extend that circle of parties in ways that forced a standoff during negotiations. An early draft of the Multimedia Guidelines, for example, stated that the "participants" in the negotiation agreed to various of its terms. The list of participants encompassed nearly any organization whose representatives appeared at any meeting. To state that all such parties had agreed to anything in the guidelines was simply an objective error. For the text of the Multimedia Guidelines with language indicating agreement by the "participants," see MULTIMEDIA COMMTITEE PRINT, supra note 4, at 1-2. The present author raised this concern at the CONFU meeting of May 17, 1997, and urged that the word "endorser" replace the word "participants" in such statements. Over strenuous objections from the lead supporters of the Multimedia Guidelines, the assembled group accepted the changes. See CONFU FINAL REPORT, supra note 4 , at 50 . This accomplishment at the CONFU meeting is hardly braggadocio. After two and a half years of meetings, that word change may be this writer's most meaningful influence on the CONFU Guidelines. See supra note 4.

432 See supra text accompanying notes 400-02. 
themselves either the users or the rightsholders of copyrighted materials that are the subject of the guidelines. Therefore, the parties certainly do not have authority to enter into license agreements. Second, the conduct of negotiations would undoubtedly be considerably different if emphasis were on licensing and not fair use. Most important, negotiated guidelines for fair use acknowledge some potential variation from the defined standard. For example, the Classroom Guidelines are explicitly minimum and not maximum standards, ${ }^{433}$ so the guidelines themselves anticipate fair use beyond their own rigors. Such is the nature of fair use. But it would be a strange license indeed that allowed a variable and unspecified right of use.

\section{Guidelines as a Substitution for Fair Use}

Fair-use guidelines also have potential for offering a standard when the individual seeking guidance abandons the four factors in the law-often in a state of bewilderment or frustration. Many instructors and librarians, individuals who are expected to follow fair use, find the statutory standard distinctly unsettling. That lack of comfort with variability in the law was the essential motivation for developing the guidelines in the first place. If the guidelines are not the law, they may instead be a substitute for the law. They may be a reflection of activity similar to fair use that is deemed to be workable and tolerable to the supporting parties. ${ }^{434}$ The guidelines have become surrogates for a law that many individuals simply find unwieldy or disconcerting.

\section{The Proprietor's View: Tolerable Behavior}

To the extent that the guidelines are endorsed by publishers, authors, and other proprietor groups - especially if those groups seek to profit from their copyrights-then the guidelines may be little more than a designation of activities that the commercial interests are prepared to tolerate, regardless of whatever the law allows. Such an approach to guidelines may bear some resemblance to fair use and the four factors, but more likely the guidelines will circumscribe a zone of activity that copyright proprietors are either unwilling or unable to enforce, or that are not likely to generate reasonable revenue from future licensing. ${ }^{435}$ They may

433 See supra text accompanying note 45.

${ }^{434}$ Bemard Zidar, Fair Use and the Code of the Schoolyard: Can Copyshops Compile Coursepacks Consistent with Copyright?, 46 EMORY L.J. 1363, 1406 (1997) ("The Classroom Guidelines represent a balance, struck by the House and Senate conferees and approved by Congress, between the benefit to society derived from allowing students to use certain materials fairly and the benefit which would flow from protecting the copyright holder's monopoly.").

435 The notion of acceptable behavior and the safe harbor are closely related. See Zidar, supra note 434 , at 1406 . Zidar states: 
also embody some quantum of activity that might be politically expedient to grant in order to gain some support for the guidelines. ${ }^{436}$

Strong support for guidelines within the publishing industry suggests that they have passed at least a test of tolerance. ${ }^{437}$ The publishing industry has the extraordinary privilege of being a plaintiff in most copyright litigation that might involve the guidelines. ${ }^{438}$ As the copyright owners, publishers are ordinarily able to decide whether or not a case is proper or beneficial for its own interests. The commercial publishers are also best positioned to relate the guidelines to effects on their markets. They are understandably resistant to any fair-use guidelines that interfere with current or prospective markets. While the fourth factor of the fairuse statute emphasizes market effects, ${ }^{439}$ a commercial proprietor acting in its own self-interest would not have any inclination to accept a fair-use standard that would require abandonment of reasonable markets. Thus, the guidelines that have strong approval from the publishing industry may be viewed as measures of fair use that are acceptable to the industry simply because they do not interfere with

The fact that the Guidelines purport to represent a "safe harbor" indicates that use of copyrighted materials in a manner which complies with the Guidelines does not inflict market harm upon the copyright holder. Similarly, the ALA and Wisconsin policies were also drafted to illustrate instances in which copying for classroom use was harmless to the copyright owner.

Id. For a discussion of the ALA and Wisconsin policies mentioned in the preceding citation, see CREWS, supra note 50, at 47-53.

436 Copyright owners often concede certain activity as fair use for many different reasons. For example, in West Publishing Co. v. Mead Data Central, Inc., 799 F.2d 1219 (8th Cir. 1986), West sought to claim copyright protection for its compilation of court rulings as published in bound volumes of court reporters. To effect that claim of compilation copyright, West needed to assert protection of its pagination in the reporters. See id. at 1219. Nevertheless, West conceded without challenge that citing to the first page of any case would be fair use. Id. at 1222. West no doubt had many reasons for making that concession. Among those reasons might have been political expediency: to claim that right would be to assert that all references to West cases are themselves infringements-making every judge who hands down a written opinion a likely infringer. Such a claim is clearly not an effective way to win the judge's support. Another reason is self-interest. West's economic strength lies in the fact that its reports are the standard tool for citing cases; to discourage citation to West publications would be to undercut the company's economic viability.

437 An anecdotal example of the tolerance test was the unwillingness of a representative of a motion picture studio to endorse the Multimedia Guidelines. During a public meeting of CONFU, attended by this article's author, the representative explicitly declined to endorse any guidelines that allowed any copying of any of its works.

438 A review of the cases examined in this article confirms that publishers are often the plaintiffs. Textbook publishers sued Michigan Document Services, Inc., and Kinko's Graphics Corporation. See Princeton Univ. Press v. Mich. Document Servs., Inc., 99 F.3d 1381 (6th Cir. 1996); Basic Books, Inc. v. Kinko's Graphics Corp., 758 F. Supp. 1522 (S.D.N.Y. 1991). Journal publishers sued Texaco Inc. See Am. Geophysical Union v. Texaco Inc. 60 F.3d 913 (2d Cir. 1995).

43917 U.S.C. $\$ 107(4)$ (1994). 
activities that the industry could realistically control or enforce, or from which it may derive appreciable profits.

One could also argue the opposite: an agreement with assent from educators or librarians is suspect, because they are unlikely to accept an agreement that does not meet either their expectations of fair use or their practical needs. This perspective, however, is somewhat less persuasive, primarily because the community of users is not positioned to bring litigation. ${ }^{440}$ Educators are the ones who will endure the litigation as defendants. Educators also have few resources to withstand litigation, and therefore are not as well situated to resist undesirable guidelines through legal action.

\section{The User's View: Acting in Good Faith}

Good faith is a crucial concept for educators and librarians, not only because of its ethical overtones for proper and lawful behavior, but also because goodfaith decisions about the exercise of fair use are sanctioned under the law in one most important respect: the remittance of statutory damages. Statutory damages are available to copyright owners who successfully prove infringement, ${ }^{441}$ but generally only if the work had been registered before the infringement occurred. ${ }^{442}$ The copyright owner may always seek recovery of damages or lost profits, but may opt for statutory damages, ${ }^{443}$ and may want to opt for them, if the actual damages are modest or nominal. Statutory damages allow the court to award up to $\$ 30,000$ per work infringed. 444 Statutory damages may reach as high as $\$ 150,000$ if the infringement was "willful." 445 On the other hand, statutory damages may be remitted, if the court finds that the infringer was "innocent" or acted in good faith. 446

440 An educator could conceivably bring an action seeking declaratory judgement that activities are within fair use, but no such action by educators has been reported. Declaratory judgment actions have been brought by some commercial parties, but only rarely. See, e.g., On Command Video Corp. v. Columbia Pictures Indus., 777 F. Supp. 787 (N.D. Cal. 1991) (seeking declaratory judgment that a system for viewing videotapes of motion pictures in hotel rooms is not a public performance).

441 See 17 U.S.C. $§ 504(c)$ (1994 \& Supp. IV 1998).

$442 \S 411$.

$443 \S 504(\mathrm{a})$.

$444 \S 504(\mathrm{c})(1)$.

$445 \S 504(\mathrm{c})(2)$.

446 Id. The statute directs:

In a case where the infringer sustains the burden of proving, and the court finds, that such infringer was not aware and had no reason to believe that his or her acts constituted an infringement of copyright, the court in its discretion may reduce the award of statutory damages to a sum of not less than $\$ 200$.

Id. 
The general remittance provision applies to both nonprofit and for-profit defendants who can prove that they were "not aware and had no reason to believe" that the activities constituted copyright infringement. 447 In that event, the statutory damages may drop to as low as $\$ 200$, in the court's discretion. In the case of an infringer who is an "employee or agent" of a nonprofit educational institution, library, or archives, statutory damages may be eliminated altogether, if the infringer can demonstrate that he or she "believed and had reasonable grounds for believing that his or her use of the copyrighted work was a fair use under section 107."448 Congress was tacitly acknowledging that fair use is open to interpretation, and that one could reasonably conclude that an activity was within fair use, only to have the court rule otherwise. To relieve the tension of that uncertainty, Congress eliminated one of the largest financial consequences of infringement for educators and librarians who apply fair use in a reasonable manner. ${ }^{449}$ That reasonable, balanced application is the essence of good faith. ${ }^{450}$

The Kinko's decision indirectly explored the interrelationship between guidelines and good faith. The defendant, Kinko's Graphics Corporation, prepared a "Handbook" for its employees, in which the company acknowledged that the Classroom Guidelines would be of little assistance for application of fair use, because "almost every case of college or university level copying will reach beyond the scope of the limits." itself" from the guidelines, the court was highly critical when it found that Kinko's offered nothing in its place. 452 The absence of guidance about fair use undermined its search for "good faith":

Kinko's instructions to its workers possessed little of the nuance of the copyright law. They provided no hypothetical situations nor any factual summary of the state of the law presently. There was no mention of the facts of the Sony case, the Salinger case, the Harper \& Row case or others which may illustrate some of the complexities of this doctrine. This can hardly be considered a "good faith" effort on Kinko's part to

447 Id.

$448 \mathrm{Id}$.

449 One commentator calls this provision "probably the single greatest source of educators' mistaken belief that they are immune to lawsuit for infringement." Wagner, supra note 236 , at 18 . Wagner is correct in emphasizing that the provision does not exonerate educators; it only holds the possibility of limiting liability for statutory damages. Yet she argues that Congress should repeal this protection for educators, asserting that educational institutions are "giants" akin to "Fortune-500" corporations, and educators should be presumed to understand copyright law and be denied any defense as "innocent infringer[s]." Id. at 18-19.

450 One writer called this protection from statutory damages a "part of the Magna Carta for educators" in the Copyright Act. Roger D. Billings, Jr., Off-the-Air Videorecording, Faceto-Face Teaching, and the 1976 Copyright Act, 4 NO. KY. L. REV. 225, 242 (1977).

451 Basic Books, Inc. v. Kinko's Graphics Corp., 758 F. Supp. 1522, 1545 (S.D.N.Y. 1991).

452 Id. 
educate their employees. To the contrary, it appears more to be a way to "cover" themselves while Kinko's remained willfully blind to the consequences of their activity. 453

To the Kinko's court, good faith may be found in guidance that does not necessarily embody standard guidelines. Good faith may be found in general explanations of the law and its general directions for how to respond to common situations. Good faith may appear in summaries of major cases delivered in a manner that can serve to educate the staff and move them toward compliance with the law. Good faith does not mean that the employees of Kinko's-or the faculty, librarians, or staff of a college or university-must ultimately behave within the scope of fair use, but they must have reason to believe that they are doing so. General explanations of the law can serve that objective. 454

Are guidelines therefore an instrument for establishing good faith? They unquestionably can be. A good set of guidelines delivered to employees, faculty, or anyone else in a position to make fair-use decisions may demonstrate the good faith of the organization, and the application of the guidelines by the individual can manifest that person's good faith as well. But the Kinko's decision tells us that a relevant set of guidelines is not the sole method for establishing good faith; general discussion of fair use or alternative interpretations may serve the objective .of good faith every bit as well.

Although a set of guidelines may be a valuable tool for establishing good faith, the objective of finding good faith may reveal that many of the existing guidelines are not well suited to serving that desired end. First, few courts would likely conclude that any of the guidelines is not at least a good-faith attempt to interpret fair use, even though reasonable analyses could differ widely on the extent to which one may deviate from the guidelines and still remain within the parameters of section 107.455 Yet many of the guidelines, notably the Classroom Guidelines, reach far beyond the quest for good faith. They instead demarcate a strict line, measured by counting words and instances of copying, in an effort to define fair use. ${ }^{456}$ They are, at their core, a rigid confine on the flexibility that Congress intended to give the law. They also apply only to narrow situations and offer little guidance for the diverse circumstances where fair use may apply. Good faith, by contrast, may instead be better served by a more general understanding of the law, as was sought by the court in the Kinko's case.

453 Id.

${ }^{454}$ For an example of a publication widely circulated at large universities, in part to serve this objective, see CONSORTIMM FOR EDUCATIONAL TECHNOLOGY FOR UNIVERSTYY SYSTEMS, FAIR USE OF COPYRIGHTED WORKS: A CRUCIAL ELEMENT IN EDUCATING AMERICA (1995).

455 The guidelines may also help establish good faith even though they may not ultimately pass scrutiny under fair-use law. See supra Part IV.A.1.

456 See supra text accompanying note 70-76. 
A second problem with existing guidelines and the quest for good faith is that the concept of good faith embodied in the Copyright Act's remission of statutory damages is vastly different from a meticulous definition of fair use. The Act's notion of good faith is one meant to protect the well-meaning member of the education or library community who made a reasonable determination of fair use, but instead was found by a court to be an infringer. This concept of good faith assumes and anticipates that the behavior in question is ultimately not fair use. ${ }^{457}$ This statutory construct is not merely protection for socially beneficial pursuits of education and libraries; it is protection for parties who seek innovative applications of fair use for worthy purposes. It is protection for experimentation and extension of the law to new needs. Detailed guidelines that attempt to define fair use and that offer a sanctioned, minimalist view of fair use miss the point of the "good faith" that Congress sought to protect and encourage. The use of rigid guidelines to define "good faith" ultimately subverts congressional intent.

\section{The User's View: An Appearance of Propriety}

Colleges, universities, and libraries often have need for adopting a policy on the fair use of copyrighted works by employees, library patrons, and others. Guidelines provide a useful tool in response to that need. First, the creation of guidelines that have some external validation and provide a vague promise of protection from liability greatly ease the process of developing a policy. An organization can simply adopt the guidelines and avoid grappling with the law itself. Second, regardless of the deficiencies in the guidelines as a measure of fair use, adhering to standard guidelines can avoid questions about the appropriateness of an alternative policy statement that one may develop. Endorsement of the guidelines by various publishing groups-the likely plaintiffs in a copyright infringement action-can also demonstrate that the adopting organization at least intended to comply with standards acceptable to the party claiming the infringement.

Well-established guidelines may have multiple uses in institutional policymaking. First and foremost, the expectation may be that the guidelines will be a force on behavior, discouraging unlawful activity and helping to find the path of proper conduct. To that end, perhaps, guidelines have found their way into policy manuals and other official documentation for educational institutions, libraries, and other organizations. 458 As a formal policy standard for an organization, a set of fair-use guidelines may appear to have the authority of mandates on individual behavior. Yet a gulf too often exists between institutional ideals and individual realities. The Classroom Guidelines are an important case in

45717 U.S.C. $\S 504$ (c)(2) (Supp. IV 1998) (referring to the user in question as an "infringer").

458 See CREWS, supra note 50, at 73-74. 
point. Since their publication in 1976, the Classroom Guidelines have been a common foundation for formal policy at major universities throughout the United States. ${ }^{459}$ But their meticulous, quantitative measures of fair use are difficult and impractical to apply, and in fact few faculty members actually adhere to them. The result is an inherent tension between institutional expectations and faculty response.

Does the tension really exist? The simple existence of a widely ignored campus policy should manifest inherent tension, but ignorance of the policy may be an accepted and expected result. Organizations often do not promote new policies thoroughly among constituents, and they certainly do not rigorously enforce policies applicable to routine behaviors or to activities that are within the domain of academic freedom, such as a teacher's plans for handouts and other photocopies. The daily decision to follow or not follow the policy is typically within the individual professor's discretion and good judgement. Disparity between policy and individual decisionmaking is even more certain when the policy makes intrusive and impractical demands. If a differential between policy and actual practice is common and unsurprising, why should policymakers within the institution bother to make a policy at all? If a consciously made reason exists, it may be deceptively simple: to protect the institution from any unlawful activities of its employees.

The policy that fails to serve the individual instructor may still serve the institution. Imagine this simple scenario: A professor is accused of making photocopies for classroom handouts in excess of the Classroom Guidelines. Her university will also be implicated and will undoubtedly face possible exposure on an agency theory or on other grounds for vicarious liability. Although the university may ultimately be unable to escape sharing legal liability for the deeds of its employees, the university will be able to demonstrate its good-faith and its official expectation of rigorous copyright compliance by pointing to the Classroom Guidelines available to all faculty members in the official policy manual. 460

If such posturing by the university does not, in fact, exculpate the institution from some or all liability, the existence of the policy can become the public display of the university's intention to follow the law strictly and not to sanction violations. The existence of the formal policy also becomes the safe fall-back position in the event that the professor is held to have infringed copyright. The university will not need to change its policy to a more demanding standard or explain its previous position; it can instead emphasize the policy it had in place all along and underscore the need for other faculty members to follow the policy it had promulgated in the first place. Suggesting that the policy protects the

459 See supra note 50.

460 The settlement in New York University effectively had this result, by requiring faculty members to comply with the Classroom Guidelines. The university is accordingly able to distance itself from non-complying employees. See supra text accompanying notes 222-24. 
institution from its own employees has a ring of simple duplicity. Faculty members, librarians, and staff would have plenty of reason to feel alienated.

All of these shortcomings are avoidable. A policy that the institution expects to be violated should never become policy at all; all members of the academic community would lose the opportunity for reasonable and honest guidance and a chance to learn a workable copyright standard for common pursuits. Also, if the institution adopts a policy that it expects to be ignored, it is hardly serving its own interest in fostering a relationship of trust and respect with its faculty and staff. Yet the institution that adopts, for example, the Classroom Guidelines, is most likely not consciously intending either to put a stranglehold on the faculty or to set them up for conflict within the organization. Instead, the decision to adopt the Classroom Guidelines is usually the product of limited information about alternative fair-use interpretations, combined with a misperception about the relationship between guidelines and the law. Too often policymakers conclude that the well-known guidelines are the only available choice and may even be necessary to meet legal obligations. Such policymakers undoubtedly have sincere intentions, but they may still have only limited awareness of their options and the implications of the policymaking decisions.

This view of guidelines and policies invariably reeks of cynicism. Although universities and other organizations may in fact be using standard guidelines for purposes of seeking cover, the cynicism does not stem primarily from the institutional propensity to be cautious or to adopt externally validated structures, or simply to find the easily available solution to a policymaking challenge. Instead, the real fault lies with the drafters of the Classroom Guidelines themselves, for accepting a view of fair use that cannot be reasonably applied, and certainly will not be applied by busy instructors who are seeking to fulfill the demands of teaching, who function with tremendous autonomy, and who have the discretion not to make use of a work if the barriers to its adoption in the classroom are burdensome or are more interference than support. If the guidelines were more pragmatic in their application and more accurate in the articulation of fair use, the adoption of the guidelines by institutions would not generate needless tension and cynicism.

\section{Guidelines within the Academic Community}

Most characterizations of the guidelines relate them to dynamics or interests outside the educational institution. Either the guidelines are some reflection of fair-use law, or an external force shaping the institution's activities, or they manifest a relationship between the institution and the external copyright owners. The guidelines may also serve a constructive purpose inside the institution. They may be used by educational institutions as a standard for educating the academic community about copyright and fair use, or they may be a standard for taking disciplinary action against a faculty member, a student, or other member of that 
community whose activities may be copyright infringements and could give rise to liabilities.

Again, the standard fair-use guidelines fail in this attempt. As a tool for educating the community, they overlook the actual law of fair use, and they often set a standard that faculty cannot reasonably apply. ${ }^{461}$ As a result, a policy built on most of the guidelines will not necessarily convey accurate information about fair use ${ }^{462}$ and will not be well received by earnest faculty who may be looking for meaningful information. ${ }^{463}$ As a disciplinary standard, they are similarly flawed. An institution that may base internal reviews and discipline on the confined standards of most guidelines would be engaged in policy action stretching far beyond anything that the law might anticipate. 464 To build the guidelines into formal university policy, to which faculty may be held accountable, is to suggest that the institution could - at least theoretically - be in turn held accountable to enforce its own policy through disciplinary procedures.

\section{A LEGAL THEORY OF FAIR-USE GUIDELINES}

\section{A. Relationship of Guidelines to Legal Theory}

If existing fair-use guidelines bear little relationship to fair-use law, but continue to persist and prevail in many communities, they must serve purposes that the law has been unable to achieve. In many instances, individuals unprepared to work with the flexibility of fair-use law often turn to standard guidelines in quest of relative certainty or to expedite the decisions surrounding

461 See supra text accompanying notes 356-79.

462 The Digital Millennium Copyright Act, Pub. L. No. 105-304, § 202(a), 112 Stat. 2860, 2881-82 (1998) (codified as 17 U.S.C. $\S 512(e)(1)(c)$ (Supp. IV 1998)), calls in part for educational institutions to provide copyright information to "all users" of its computer network systems as one condition of the university's potential ability to avoid copyright infringement liability as a "service provider." In unusually assertive and specific language, the statute specifies that the information must "accurately describe" the law and must "promote compliance with" copyright laws. Id. Given the shortcomings of the guidelines examined in this article, one might reasonably consider whether distributing them to the university community might be insufficient to satisfy this requirement of distributing accurate information.

463 See supra text accompanying notes 62-64.

464 Generally speaking, the law has not required policing of employees to find and address infringements. See, e.g., 17 U.S.C. § 512(m) (Supp. IV 1998). Nevertheless, an organization seeking scrupulously to avoid liabilities may well choose to monitor activities in order to identify and eradicate possible infringements, although such efforts have stirred serious concerns about academic freedom and free speech. For example, Camegie Mellon University recently reviewed websites on its servers and removed allegedly infringing music files. Kelly McCollum, How Forcefully Should Universities Enforce Copyright Law on Audio Files?, CHRON. HIGHER ED., Nov. 19, 1999, at A59. 
policymaking and implementation. 465 The guidelines also offer some perceived promise of preventing liability. 466 Lawmaking and governmental bodies also cling in various degrees to the concept of guidelines for fair use. Courts occasionally reference the guidelines, and the CONFU report received support from various federal agencies. ${ }^{467}$ However weak the tie may be between the guidelines and the law, some tie exists. That connection between guidelines and law may be described and critiqued in various terms.

Various theories from legal analysis may be applied to the circumstances surrounding the origin and application of the guidelines in order to discern a model for better understanding them. This part of the article will suggest that concepts of normative and positive law may provide a framework for understanding the legal significance of the guidelines. ${ }^{468}$ Application of these theories, however, will also demonstrate that while they may offer a meaningful legal construct for understanding fair-use guidelines, these theories also reveal further weaknesses in the guidelines.

\section{B. New Legal Theory for Fair-Use Guidelines}

\section{Positivist Concept of Guidelines}

A theory of positive law is rooted in the concept of law having authority to impose a standard or a particular behavior on individuals. ${ }^{469}$ The law can set an expectation, and violations will be penalized. Professor Ronald Dworkin has been a leading analyst of legal positivism, ${ }^{470}$ and one of his fundamental principles is that the law, with its authoritative effects, can be identified by its pedigree. 471 The

465 Some commentators continue to demand more certainty in the law. See, e.g., Trevor Cox, Information and the Internet: Understanding the Emerging Legal Framework for Contract and Copyright Law and Problems with International Enforcement, 11 TRANSNAT'L LAW. 23, 48 (1998) ("A better approach would be to amend the United States Copyright Act to establish guidelines for fair use over the Internet and to provide basic examples for actions which would not be a copyright infringement.").

466 See Tomas A. Lipinski, Designing and Using Web-Based Materials in Education: A Web Page Legal Audit_Part I, Intellectual Property Issues, 137 WEST's EDUC. L. REP. 9, 11 (1999) (recommends adopting the Multimedia Guidelines "to minimize potential liability").

467 See supra text accompanying notes 209-12.

468 According to one study, "legal positivism refuses to go away" despite steady criticism of it. See Frederick Schauer \& Virginia J. Wise, Legal Positivism as Legal Information, 82 CORNELL L. REV. 1080, 1080 (1997).

${ }^{469}$ Legal positivism also has been described as contending that "the nature of law is contingent on human decision" and not necessarily on higher or moral principles. See id. at 1087.

470 See generally RONALD DWORKI, A MATTER OF PRINCIPLE (1985).

471 See Lloyd L. Weinreb, Law as Order, 91 HARV. L. REV. 909, 912 (1978). See also Schauer \& Wise, supra note 468, at 1093 (asserting that under positivist theories the rule of law 
pedigree of positive copyright law is found in Congress, which has the power to grant rights to authors. ${ }^{472}$ Implicit in that power is the right to curtail the extent of those rights by reserving rights-such as fair use-to the public. Assuming, however, that Congress has enacted constitutionally the fair-use statute, the legislative history also demonstrates beyond peradventure that Congress was not willing to enact more specific terms. ${ }^{473}$ Thus, the more detailed provisions of the guidelines, developed outside of Congress, deviate from the source and policy of copyright law. The guidelines fail the fundamental test of positive law.

Supporters of the guidelines, however, are well aware that the guidelines are hardly positive law with binding authority. ${ }^{474}$ Taking the guidelines to the courts, therefore, has been an attempt to secure what Congress could not grant: a pedigree for the guidelines. 475 The text of the guidelines may well be rooted in private negotiations, but their adoption by a court as a standard in a fair-use decision would elevate the guidelines to a status with a new pedigree; they would emerge from such a court ruling with the quality of being law. 476 To date, however, this effort has failed. 477 The $M D S$ decision referred to guidelines as a "safe harbor" and not a legal standard.478 The court also belabored the effort to rule against activity that was, by the court's reckoning, "light years" beyond the guidelines. ${ }^{479}$ If the guidelines were law, any breach of their limits would be an

is "source-based"). Roger A. Shiner argues that under a positivist theory, "authority" is not the same as "validity" of the law. He attributes validity to the "pedigree" of the law "by the rule of recognition of the legal system." ROGER A. SHINER, NORM AND NATURE: THE MOVEMENTS OF LEGAL THOUGHT 24 (1992). He adds this statement about authority: "If the law has authority, then the demands that the law makes of us it has a right to make of us; its requirements are such that we ought to conform to them." Id.

472 Specifically, the U.S. Constitution authorizes Congress to grant to "Authors" the "Exclusive right" to their works. U.S. CONST., art. I., § 8, cl. 8.

473 H.R. REP. No. 94-1476 (1976).

474 On the other hand, the fair-use guidelines could be understood by legal positivists as simply filling the gaps and resolving lingering ambiguities in the statutes from Congress: "Modern legal positivists believe that problems of legal indeterminacy (the failure of rules to guide decision-makers to correct answers) were minor difficulties in decision making that could be resolved by institutional choices based on the competency of the decision maker to resolve ambiguity in language." See GARY MNDA, POSTMODERN LEGAL MOVEMENTS: LAW AND JURISPRUDENCE AT CENTURY'S END 49 (1995).

475 For example, a "source-based conception of law is necessarily informational." That is, the authority of the law depends on its source and on information to justify the authority of that sources. See Schauer \& Wise, supra note 468, at 1095.

476 Similarly, the effort to include guidelines in a congressional report also gives them the appearance of a formal pedigree. For a discussion of such developments, see supra text accompanying notes 215-16.

477 See supra Part III.

478 Princeton Univ. Press v. Mich. Document Servs., Inc., 99 F.3d 1381, 1391 (6th Cir. 1996.

${ }^{479}$ Id.; see also supra text accompanying note 252. 
easy case of infringement. Even more pointedly, the Kinko's decision rejected important provisions of the Classroom Guidelines. ${ }^{480}$ Not only was that court not adhering to the guidelines, but it was also free to reject them.

\section{Normative Concept of Guidelines}

If the guidelines are not positive law, they instead may be comprehended as a "normative" conception of fair use. 481 General theories of normative law relate to what the law ought to be, rather than what it really may be or how individuals may in fact behave in an environment affected by law. 482 The Classroom Guidelines, for example, articulate an agreed measure of fair use. The negotiators developed the guidelines on a relatively rigorous schedule and at the behest of members of Congress, who sought to avoid detailed legislation. This article has already demonstrated repeatedly that the guidelines ultimately bear little relationship to the law of fair use and the four statutory factors. ${ }^{483}$ Moreover, one need not look far within the academic community to find that few, if any, individuals are actually counting words on a page before making photocopies for classroom distribution. ${ }^{484}$ By this standard, the guidelines are not a reflection of either the law or actual practice. They may instead be a declaration of the law that the parties believe ought to apply. ${ }^{485}$

Moreover, as a tool for transforming behavior, the guidelines have largely failed. Few members of the academic community appear to accept the premise that the guidelines, with their meticulous limits on fair use, are a viable statement

480 Basic Books, Inc. v. Kinko's Graphics Corp., 758 F. Supp. 1522, 1537 (S.D.N.Y. 1991); see also supra text accompanying notes 234-39.

481 One study makes this description of a normative perspective of the law: "But the law can also be studied to determine what legal principles and rules are justifiable or desirable." MiCHAEL D. BAYLES, PRINCIPLES OF LAW: A NORMATIVE ANALYSIS 1 (1987).

482 A normative theory also allows current analysis to examine critically the appropriateness of applying outmoded law. See, e.g., M.B.W. Sinclair, Statutory Reasoning, 46 DRAKE L. REV. 299, 319-20 (1997) (examining the Supreme Court's rejection of a doctrine of affirmative action that had become obsolete).

483 A normative analysis would not necessarily be concerned about the divergence between law and guidelines: "One can have a perfectly good explanation of why a court or legislature adopted a law, but the law be quite unjustifiable." See BAYLES, supra note 481, at 3.

484 See, e.g., Wagner, supra note 236, at 12 ("Rather, the academic community has ignored the Guidelines.').

485 Note particularly that the guidelines are a statement of fair use that the parties to them believe other individuals "ought" to apply and follow. Again, the guidelines may have a "positivist" appearance in that regard, but they lack an authoritative source. According to one analysis, they therefore do not embody "legitimate authority," but instead have "de facto authority," which is further described as "an ill-formed expression." See SHINER, supra note 471 , at 24. 
of the rule of law which they "ought" to follow. 486 On the other hand, supporters of the guidelines have been successful in persuading some members of the academic community that the guidelines are the standard that "ought" to be adopted in formal policy statements. ${ }^{487}$ Numerous colleges, universities, and libraries have adopted some of the guidelines as formal policy statements, even if they ultimately do not shape the behavior of individuals who are subject to the policies. Policymakers, therefore, seem to believe that reliance on the guidelines serves purposes other than guiding individual behavior. 488 Merely having a policy premised on the guidelines may provide a defense against institutional liability, or it may demonstrate good faith. If the institution is pursuing those goals, rather than the goals of shaping behavior, supporters of the guidelines have succeeded in imbuing the guidelines with a limited normative quality. The guidelines articulate the standard that "ought" to be in policies, even if individuals are unconvinced that they ought to follow that same standard. 489

\section{Combined Theory}

Neither positive nor normative theory seems to describe accurately or satisfactorily the legal status of the guidelines, yet the guidelines oddly possess a peculiar appearance of both normative and positive qualities. They are portrayed initially as normative standards, and they are advocated later as positive standards. ${ }^{490}$ When the guidelines originate, with support from some members of the educational community, the guidelines take on the appearance of fair-use limitations that either reflect practices within the academic community or that are acceptable to decisionmakers who have the authority to impose guidelines as binding standards at educational institutions. ${ }^{491}$ Either of these perceptions of the

486 See supra note 484.

487 See supra note 50.

488 See supra notes $441-60$.

489 According to one commentator with respect to the CONFU guidelines, "Ongoing legislative or quasi-legislative attempts to deal with fair use issues perpetuate a paradigm, however, similar to that implemented by shrink-wrap, that defines 'appropriate' use before the normative dimensions of that use have been fully explored." See Michael J. Madison, LegalWare: Contract and Copyright in the Digital Age, 67 FoRDHAM L. REV. 1025, 1099 n.271 (1998).

490 One analysis of the Kinko's decision seems to make exactly this point, apparently with satisfaction of its appropriateness. See Wagner, supra note 236, at 14-15. While that writer is critical of the Classroom Guidelines for higher education, she notes that educators did sign onto the guidelines when they were first drafted, and educators have not taken the initiative in decades to seek a renegotiation of them. Id. Thus, the guidelines, by this analysis, have a normative quality at their inception and then attain an authoritative quality due to inaction by educators. See Wagner, supra note 236, at 14-15.

491 At least one study has struggled with the difficulty of works that "look legal" even though they lack truly "positive" legal qualities. See Schauer \& Wise, supra note 468, at 1105. 
guidelines gives them the appearance of having normative qualities. If the guidelines reflect actual practices, they are truly normative; if they are made binding on the institutions and influence practices by imposition, they become positive.

Nevertheless, given the wide adoption of the guidelines in formal policies, the guidelines have the appearance of a normative standard with respect to actual faculty practices. ${ }^{492}$ That appearance has been deceiving. It has been used as a foundation-however unstable-for advocating that the guidelines should therefore be integrated into the law, and accepted by the courts as positive law. Although that effort has failed, ${ }^{493}$ strong supporters of the guidelines continue to distribute information designed to lead readers to conclude that the courts have, in fact, adopted the guidelines. ${ }^{494}$ The few references in court rulings are often taken out of context and sometimes misinterpreted in order to lead readers to an invalid conclusion that the guidelines are positive law. Accepting that the guidelines truly have normative or positive qualities would be seriously misleading. Yet the common perceptions of the guidelines, detailed in Part IV, reveal that they are often characterized as accurate statements of law or of practice. The result is an illusion - an illusion that the guidelines have a basis in fair-use law and enjoy the force and respect that the law is due.

This normative and positive analysis further demonstrates that the creation and dissemination of the guidelines is carefully managed to achieve the appropriate illusion. Participation by educational institutions in the creation of the guidelines serves the fundamental purpose of generating the illusion of normative qualities. The appearance of normative qualities also gives them some credibility when brought before courts in infringement cases. The appearance that the guidelines are widely accepted in the educational community is a normative quality that a jurist may well accept. Any reference to the guidelines by the court, in turn, gives the guidelines the appearance of having positive qualities. Judicial

The Register of Copyrights also has called fair-use guidelines "a curious U.S. invention" but implied that they have normative qualities by suggesting that guidelines "symbolize consensus" among interested parties. David Ladd, Private Use, Public Policy: Copyright and Home Recording, 56 WILSONLIBR. BULL. 266, 269 (1981).

492 For a study showing the widespread adoption of standard guidelines by research universities, see CREWS, supra note 50, at 73-74.

493 For an analysis of the relevant cases, demonstrating that no court has adopted any of the guidelines as a legal standard, see supra Part III.

494 NATIONAL ASSOCIATION OF COLLEGE STORES ET AL., QUESTIONS AND ANSWERS ON COPYRIGHT FOR THE CAMPUS COMMUNITY 4 (1993). The questions and answers state:

Although some limited copying which does not fall within these [Classroom] guidelines (and which is not expressly prohibited under Prohibitions A through F described below) may still qualify as permissible conduct under the copyright law, copying which does comply with these guidelines generally constitutes permissible conduct under the current copyright law.

Id. 
notice of the guidelines certainly does not make them positive law, but it has facilitated the impression that they are positive law, particularly among the educators, librarians, and others who are not prepared to distinguish enforceable law from general statements in a court decision. The illusion of positive law thus further reinforces the academic community's regard for the guidelines.

The result of this dynamic is a spiral of misperception and sanctioned misconstruction of the law. The appearance of normative qualities leads to bestowal of positive traits; the appearance of positive qualities makes the guidelines more compelling for the academic community and more widely adopted. Expanded adoption reinforces the normative aspects. Even if these qualities are without merit and even vacuous, their illusory validity gives the guidelines important meaning in the academic community that is unlikely to invest scarce resources, and unlikely to muster specialized expertise, to analyze legal subtleties. At the source of this illusion is the unwillingness of the academic community to look critically at the guidelines, the failure of the courts to reject them in the application of fair-use law, and the eagerness of proponents to encourage development and dissemination of meticulous standards that have the insidious effect of eroding and distorting fair use.

\section{THE FUTURE OF FAIR-USE GUIDELINES: OBSERVATIONS AND RECOMMENDATIONS}

Regardless of the serious disconnect between the guidelines and the law, guidelines nevertheless persist. Existing guidelines will continue to arise in court rulings and in institutional policies. They will appear in future books and other resources about copyright - often with the implications that they are a meaningful articulation of fair use law. Undoubtedly, the roster of existing guidelines, from the Classroom Guidelines through CONFU, will also be put forth as a foundation or model for the crafting of future standards. This article accordingly offers three sets of observations drawn from the preceding analysis. The first set of observations relates to the legal status of guidelines themselves. The second set of observations identifies the functional differences between guidelines and the law-observations that suggest how interested parties ought to respond to the guidelines. The third set of observations will propose how the inevitable process of crafting guidelines may be improved in the future in order to avoid the failures of guidelines from the past.

\section{A. Legal Status of Fair-Use Guidelines}

The analyses of the origins of guidelines and the several cases examining them, particularly the Classroom Guidelines, allow the following inferences and lessons about the role and meaning of guidelines. 
None of the fair-use guidelines is law. None of the guidelines originates from a source with authority to make law. Congress never has adopted any of the guidelines into legislation, and no court has accepted them as a standard of fair use applicable to any situation. Indeed, Congress and the courts have acted carefully and explicitly to assure that they have not elevated any of the guidelines to a lawfully binding standard.

The guidelines reflect a minimalistic view of fair use. By their own explicit statements, many of the guidelines are "minimum" measures of fair use. Moreover, the substantive measure of fair use articulated in the guidelines is far narrower than any limit of fair use established in any court ruling on facts analogous to the guidelines. In the $M D S$ decision, for example, the court found infringement in a situation involving copying that was "light years" beyond the guidelines. ${ }^{495}$ On the other hand, the guidelines often contain "prohibitions" that users are expected not to exceed, even if otherwise staying within the rest of the standards. ${ }^{496}$ In that regard, the guidelines are maximum standards in the guise of minimums.

The guidelines reflect a view of fair use to which proprietor groups are prepared to acquiesce as either unequivocally within fair use or beyond the scope of activity that is worth challenging. By winning the endorsement of publisher groups and other proprietors with an interest in challenging some uses as unlawful, the guidelines undoubtedly address a practical standard that reflects a business strategy, rather than a legal reality. Publishers, in particular, likely have little or no interest in supporting guidelines that would seriously threaten business objectives, even if they honestly believe that the guidelines accurately describe fair use.

The guidelines do not displace the importance of applying the four factors from the statute. The law of fair use is ultimately founded on the four factors. 497 Just as the courts have made clear that they do not view the guidelines as a substitute for the law, so should individuals working with fair use not abandon the law and allow the guidelines to become a substitute. To do so, ironically, places the user at risk of following a standard with no legal basis.

The guidelines are too rigorous to be a measure of "good-faith" behavior. The U.S. Copyright Act provides important protection for some parties-notably educators, librarians, and others who are typically the object of existing fair-use guidelines - when those parties make decisions in good faith. 498 Not only are the guidelines usually far more rigorous and narrow than analogous case law would suggest necessary, but they are also more rigorous than necessary to demonstrate good faith. Most certainly, behavior strictly within the guidelines would likely be

\footnotetext{
495 See supra text accompanying note 252.

496 See supra text accompanying notes $74-76$.

497 See supra text accompanying notes $21-24$.

49817 U.S.C. § 504(c)(2) (Supp. IV 1998).
} 
viewed as good faith, but a good-faith reliance on the four factors would allow greater flexibility for meeting unpredicted needs. Moreover, if the guidelines evidence a standard that is gauged to meet a tolerance level of proprietors, it also would likely bear little relationship to a good-faith application of fair use to new and challenging circumstances.

The guidelines are nevertheless a compelling tool for educators who seek to apply fair use and create policies. The guidelines have the appearance of having an official status, and they are widely accepted by the publishing industry and other proprietor groups who may be potential plaintiffs in copyright actions against the educators. If the objective of an educator making policy is to avoid litigation, adopting and following the guidelines certainly offers the prospect of discouraging a lawsuit.

The guidelines are compelling to courts. Courts struggle with the unsettled nature of fair-use law. Judges attempting to reach decisions about fair use undoubtedly must also perceive that the law is open to widely diverging interpretations, and that any decision would therefore be subject to potentially sharp criticism. Although the courts in all the cases examined here do reach decisions based on the factors in the statute, those same courts are also drawn to the guidelines for reasons similar to those of the educational institutions developing a fair-use policy: the external validation of the guidelines by interest groups gives them some demeanor of credibility. Accordingly, when a judicial opinion demonstrates that activity not only violates the law but also the guidelines, the court is finding some reinforcement for its ruling. If the guidelines have an appearance of validation by interested parties, then the court might perceive that the reinforcement has been previously accepted by the persons with the greatest interest in the outcome of the ruling. In sum, courts are therefore treating the guidelines as a crutch to bolster a ruling and to fend off post-decision criticism.

Fair-use guidelines have had the effect of ossiffing perceptions of fair use and denying the law its intended flexibility. To the extent that the guidelines attract attention in discussions about fair use, they are in turn drawing attention away from fair-use law itself. Worse, to the extent that the guidelines are seen as a substitute for law or as a standard with legal authority, the guidelines are suppressing all opportunity to comprehend and work with the law itself. Examples of the encroachment of guidelines on the law abound. Perhaps the most salient example is the common expectation that fair use requires classroom photocopying to be "spontaneous."499 Spontaneity is a concept that may be

499 In the midst of writing this article, I gave a presentation on copyright issues at the NERCOMP Annual Conference, held in Sturbridge, Massachusetts, on March 23, 1999. (NERCOMP is formally known as the New England Regional Computing Program.) In the context of developing a standard of fair use for an electronic reserve system, one conference attendee asked about the need to comply with the "spontaneity requirement" of fair use-yet one more example of the infiltration of the Classroom Guidelines into general understanding of 
relevant to the four factors, but certainly is not required. It is, however, required under the Classroom Guidelines. Indeed, it has its origins in the drafting of the Classroom Guidelines. Spontaneity is commonly asserted as a condition to fair use; whenever it is so asserted the guidelines are once again infiltrating our understanding of the law.

These observations, taken together, manifest a dubious role for fair-use guidelines in current law. The intention of the drafters and negotiating parties may well have been constructive and positive, and most certainly the ambitions and expectations of the parties must have been centered on a hope for a meaningful result. Whatever the subjective intent, however, the resulting guidelines have had contrary and destructive effects. The guidelines have become a convenient distraction from the responsibility of copyright owners, users, courts, and even Congress to work with the law itself. Parties with an interest in supporting the guidelines-especially publishers and others seeking a narrow application of fair use-have advocated the guidelines in litigation, in widely distributed publications, and in tacit demands and threats against educational institutions. Whatever the drafters' intent, the guidelines themselves have been distorted and imposed on the marketplace in a manner that undercuts the law of fair use itself.

\section{B. Responding to the Guidelines}

As new guidelines, with some measure of negotiated or official status, emerge from CONFU or other future pursuits, individuals and institutions will face the decision about whether to endorse, adopt, follow, or even regard the offered guidelines in their analysis of fair use. Not only will colleges, universities, publishers, and authors face such decisions, but so will congressional committees likely be confronted with the decision to support or not support future guidelines, just as a House committee did with the earlier guidelines in 1976 and 1981. Supporters of new guidelines already have demonstrated their intent to seek that imprimatur of law, by taking the Multimedia Guidelines to a House subcommittee for its approval. 500

How should this wide array of reviewers of fair-use guidelines make a determination of support or non-support? Based on this analysis, reviewers of any guidelines should consider the following traits of copyright law as compared to the guidelines, and consider whether the guidelines are a real improvement. ${ }^{501}$

None of the fair-use guidelines has the force of law; only statutes and court rulings have that authority. If an educator is looking for the standard to which he

fair-use law. I frequently receive the same question at numerous academic conferences around the country.

500 See MULTIMEDIA COMMTTEE PRINT, supra note 4.

501 These comparisons of law and guidelines are based in part on an earlier publication by the present author. See Kenneth D. Crews, Fair Use and Higher Education: Are Guidelines the Answer?, 83 ACADEME, Nov.-Dec. 1997, at 38. 
or she actually must adhere, only the law can offer that guidance. Guidelines cannot. Guidelines are interpretations of the law and are absolutely not the only interpretation possible. Guidelines, therefore, cannot give assurance that a user is actually operating within the law.

The law is actually a less complex measure of fair use than are most guidelines. The law of fair use depends principally on four factors which are summarized and described in many different publications. ${ }^{502}$ The guidelines often depend on a multiplicity of variables and include many requirements and prohibitions that are not found in the law. For example, the CONFU guidelines on production of multimedia works restrict the length of time that a professor may keep and use the finished work and require notices that the professor is exercising fair use. ${ }^{503}$ No such obligations exist in the law. The guidelines further itemize a long list of conditions related to quantity, purpose of use, and market effects. 504

The law of fair use is flexible to meet changing needs and circumstances, while the guidelines are rigid. Congress intended for the law to be flexible, and court rulings have affirmed that generalizations about fair use are simply not valid. For example, the measure of the amount of a work that may be copied is highly fluid. By contrast, guidelines usually include rigorous quantity limits that hardly begin to reflect the robust character of fair use. One court has ruled that reprinting three hundred words from an earlier work was too much, while another case allowed several thousand words. ${ }^{505}$ These decisions are not inconsistent; they reveal that fair use depends on specific circumstances of each use.

Staying within fair-use law prevents infringement, but the guidelines do not offer even a "safe harbor." Most guidelines from the past and from CONFU are by their own description "minimum" measures of fair use, implying that they will protect compliant users from infringement liability. But representatives of many copyright owners have refused steadfastly to call the guidelines a "safe harbor," reserving the right to bring infringement actions even against an individual or institution that stays meticulously within the limits. If the guidelines are admittedly not a "safe harbor," then they most assuredly are not any measure of fair use at all.

Copyright law provides important protection for well-meaning faculty and others who apply fair use, but guidelines offer no actual protection. When members of university and library communities have "reasonable grounds" to believe their activities are within fair use, the Copyright Act exonerates these individuals and the institution from some of the monetary liability that may result if the activities are found to be an infringement. Congress structured the law to

502 See, for example, many of the works listed in supra note 7.

503 See supra text accompanying notes 171-72.

504 See supra text accompanying notes $162-70$.

505 See Harper \& Row Publishers, Inc. v. Nation Enters., 471 U.S. 539, 569 (1985) (quoting three hundred words was beyond fair use); Maxtone-Graham v. Burtchaell, 803 F.2d 1253,1265 (2d Cir. 1986) (quoting seven thousand words was within fair use). 
encourage professors, librarians, and others within the non-profit educational arena to pursue fair use in good faith. The reduction of damages should motivate positive and constructive application of fair use, offer considerable peace of mind, and discourage most threats of litigation. Congress granted an important protection in recognition of lingering uneasiness and the importance of advancing knowledge through a reasonable, balanced, and good-faith understanding of rights and responsibilities. No set of guidelines can offer that same combination of promises.

In the final analysis, the guidelines may actually have considerably less significance than might appear on first look. One might logically wonder, however, whether the community of educators and proprietors might not take steps to enhance the import of guidelines. After all, for those persons who desire greater certainty in their handling of fair use-although not necessarily in the law itself-and do not prefer to make decisions based on the law of fair use, the guidelines are a convenient recourse. They streamline the decision about the content of a policy, while they actually compound the complexity of an individual's decision.

\section{Lessons for the Future Development of Guidelines}

If fair-use guidelines serve some perceived practical purposes, and are compelling to influential parties, new guidelines will undoubtedly be the subject of future negotiation and development. This analysis of existing guidelines, while revealing their serious flaws, also suggests several lessons for developing improved guidelines in the future.

Fair-use guidelines should be rooted explicitly in fair-use law. Future guidelines should begin with the framework of the factors in the statute and address their meaning for the application at issue. ${ }^{506}$ For example, a new set of guidelines on the subject of copying for electronic-reserve systems should be drafted around the statutory factors. The guidelines should begin with the actual law of fair use and summarize the procedural and implementation steps that one may take to meet the factors. In the case of electronic reserves, guidelines could address the "purpose" factor by noting, among other conditions, that the material placed on reserve must be solely for use by students in a particular course at the educational institution. The guidelines might list various other steps that one might take to meet obligations with respect to that factor, allowing the user implementing or adopting the guidelines to select from options that may be within fair use.

506 One commentator urged that faculty should return to the law of fair use and not rely on guidelines: 'Universities, individually or together, should create a policy statement or faculty guide that will provide educators with the information they need to make informed fair-use determinations. The Guidelines may be a suitable harbor for some, but informed educators should fully assert their statutory right of fair use." Kasunic, supra note 415, at 291. 
Fair-use guidelines must be flexible in their definition of the scope of fair use. Fair use in an inherently flexible doctrine, dependent on the specifics of the relevant facts of each case. Courts established that principle from the origin of the fair-use doctrine. Congress affirmed it in the enactment of the statute in 1976. More recent court rulings have militated repeatedly against any bright-line rules. Guidelines that attempt to isolate and identify a precise measure of fair use for many different situations are overtly rejecting the fundamental flexibility of the law.507 The Classroom Guidelines, the Multimedia Guidelines, and most of the fair-use guidelines make that crucial error with emphasis. They attempt to find and hit the bull's eye of a moving target.

The target is also ethereal. Almost never does a court or any other authority need to specify the boundary between fair and unfair uses. A court faced with particular facts need only determine whether those facts are on one side of the line or the other. The law does not need to define the line itself. Private parties should also not seek to define a line that is unnecessary to identify and perhaps even unknowable. The precise definition of fair use is akin to Heisenberg's "uncertainty principle" from physics: one cannot know both its empirical definition and its specific application simultaneously. 508 Perhaps borrowing from a slightly more familiar, and legal, doctrine: we cannot strictly define fair use, but we can know it when we see it.509

Fair-use guidelines should be flexible in their means for adhering to obligations under the law. The law of fair use is inherently flexible, and that flexibility is essential for fair use to meet unpredictable needs. Not only is the limit of fair use variable, but so are the means for addressing and satisfying the four factors in the statute. Thus, guidelines that offer only one means for addressing and meeting fair use subvert the essence of the law. Guidelines of the past do exactly that by, for example, setting exact quantity limits and barring any uses that may involve the making of anthologies or coursepacks. Moreover, the flexibility that the guidelines attempt to preserve by labeling them as "minimum" standards is also subverted whenever that language is stripped away, as it was in the settlement of the case against NYU. Educational institutions and other organizations that adopt the guidelines should be cautious about accepting guidelines that erode opportunities for creative application of the law.

507 Klingsporn, supra note 1, at 122 ("Instead of a series of negotiated compromises, fair use guidelines should be primarily a statement of principles, and secondarily a way to limit the effects of technological limits on fair use.").

508 See generally ALASTAIR I.M. RAE, Uncertainty Principle, in 4 MACMILLAN ENCYCLOPEDIA OF PHYSICS 1643 (1996) ('In its simplest formulation the uncertainty principle states that it is impossible to exactly define both the position and the momentum of a particle at the same time.")

${ }^{509}$ Cf. Jacobellis v. Ohio, 378 U.S. 184, 197 (1964) (Stewart, J., concurring) (regarding the effort to define pornography: "I know it when I see it."). 
No governmental agency should support or endorse any of the guidelines that do not meet prescribed standards for their development. Those standards could begin with the recommendations on this list in this article. A congressional committee, for example, should not lend its support to guidelines that are not flexible and that are not explicitly founded on the law. Of all the government agencies with an interest in the development of guidelines, the most important and influential decisionmaker of all, of course, is Congress or a congressional committee. That decisionmaker is often called upon to offer support for fair-use guidelines. Yet, Congress especially must tread cautiously when reflecting on the fair-use law it enacted more than two decades ago. Statements of congressional intent long after passage of a law may appear weighty and influential, but they are not likely to be accepted with great credulity by the citizens or the courts. Such ex post facto declarations are instead more likely to stir confusion as the guidelines often conflict with the letter or the spirit of the law itself. Similarly, statements that are not well considered or that do not reflect diverse perspectives may carry unintended influence on the marketplace of ideas.

The process of developing guidelines should include adversarial justifications and challenges of the guidelines based on law. ${ }^{510}$ In particular, government agencies should not approve or support any fair-use guidelines without a public opportunity for supporters and detractors to present arguments with respect to the legal validity of the guidelines. ${ }^{511}$ At no point in the creation of any of the guidelines was any interested party ever called upon to support any position with a legal justification. ${ }^{512}$ At no point was any interested party called upon to be accountable publicly to the law. Government agencies should hold public

510 That process already has occurred in some limited situations. To the extent that courts have considered applying any of the guidelines in a ruling, presumably the appropriateness of doing so has been the subject of briefs and oral argument. For example, in the rehearing en banc before the Sixth Circuit Court of Appeals in the MDS decision, the judges questioned critically the appropriateness of applying the Classroom Guidelines to the copying at issue. In the final decision, the court chose not to apply them. See Princeton Univ. Press v. Mich. Document Servs., Inc., 99 F.3d 1381, 1390-91 (6th Cir. 1996).

511 With respect to the early guidelines, from 1976 through 1981, administrative agencies took no formal or public position. Members or subcommittees of Congress, however, did offer general statements of support. Those statements actually focused on the process or idea of guideline development, rather than on the legal validity of the content of the guidelines. By contrast, some of the CONFU Guidelines have support from the U.S. Copyright Office and the U.S. Patent.and Trademark Office. See CONFU FINAL REPORT, supra note 4, at 57. Under the proposal offered here, the administrative agencies in particular would refrain from lending their name or auspices to the finished guidelines without a more formal scrutiny.

512 At one point in the CONFU process, the present author gave a presentation to the assembled group, showing the relationship of various elements of the draft electronic-reserve guidelines to the factors in the fair-use statute. No other presentation even remotely comparable ever occurred in any of the CONFU proceedings. Nevertheless, I now contend that that presentation was still inadequate. I would urge that a future presentation be more formally defined, with cited authorities, and leave a permanent record for later analysis and scrutiny. 
hearings and require written submission of documents that may approach legal briefs before rendering a decision to support or not support guidelines. ${ }^{513}$ One might even speculate that the endorsement of the CONFU guidelines by the U.S. Copyright Office and the U.S. Patent and Trademark Office was beyond the authority of those agencies to act.

Interested parties should not independently lead the effort to develop publicly distributed fair-use guidelines. 514 The convening of interested parties, not only to articulate views, but to lead the effort to devise broad-based guidelines, has proved to be seriously flawed. 515 The result is a negotiated statement supported only by the parties who choose to agree with the final analysis. ${ }^{516} \mathrm{~A}$ role for an independent voice with the duty of keeping a focus on the law of fair use was lacking from CONFU and all other efforts to develop most of the existing

513 This proposal would easily be burdensome to many interested parties who may be unable to retain counsel for presenting a thorough and competitive argument for or against any set of guidelines. I do not see an insurmountable concern with that argument. First, many parties in the negotiation of guidelines have been represented by well-paid legal counsel. Second, law professors and other attorneys have acted on behalf of various other parties to the negotiations. Third, even if a critical viewpoint is seriously overwhelmed by sophisticated lawyers, the government agency considering the views should be able to assess that inequality in reaching its determination. Fourth, a possible outcome of such a process could be a determination by the agency to take no position at all on the guidelines in question-to refrain from supporting or rejecting them. The agency could well take such a neutral position when the representation is clearly lopsided. One possible model for the reform of the process for creating future guidelines is "negotiated rulemaking," which brings interested parties together with government officials in an attempt to achieve consensus support for new regulations. See generally Soo-Hun Park, Judicial Review of Negotiated Rulemaking (1977) (unpublished LL.M. thesis, School of Law, Indiana University, Bloomington (on file with the Indiana University Law School Library)).

514 Brian D. Wassom, Note, Copyright Implications of "Unconventional Linking" on the World Wide Web: Framing, Deep Linking and Inlining, 49 CASE W. RES. L. REV. 181, 249 (1998) (urging establishment of a governmental agency to lead the development of guidelines).

515 Naturally, parties with an interest in fair-use determinations can still develop guidelines or interpretations for application to their own activities. Indeed, they should take exactly those steps. Colleges and universities should develop interpretations for their own needs. They may even share ideas about fair use with other institutions, and those groups may choose to follow or reject the example. This article, however, is asserting that interested parties of diverse perspective should not lead efforts to devise guidelines that will gain some governmental support and have intended application to individuals or organizations that do not voluntarily choose to follow them.

516 Klingspom, supra note 1, at 121. He states:

As CONFU's results show, consensus has become too unwieldy. The number of organized interest groups demanding to be included in forming any proposal to amend the copyright laws, combined with the speed of technological and market change, will only result in amendments that are obsolete as soon as they are passed.

Id. 
guidelines. 517 Without that voice, and an obligation to give it heed, the parties again gravitated toward an "acceptable" result, and not a result founded in the law.

\section{CONCLUSION: PERCEPTIONS AND REALITIES}

As guidelines encroach on the law of fair use and begin to displace its principles, the guidelines become a subversion of the law. The law of fair use may be deficient in many ways, and may well demand change. Congress can amend the statute, and courts can interpret it, but private parties acting outside those channels can only influence perception of the law. If distorting perceptions is the goal, the guidelines have succeeded in great measure. In the marketplace of ideas, where fair use enjoys daily application, the guidelines have shaped much of the understanding of the law. Yet in shaping perceptions, the guidelines have prevented accurate understandings of the law itself. The guidelines even have created perversions of legal understanding and prevented interested parties - and judges-from recognizing and meeting their rights and responsibilities under copyright law. 518

The stated intent of developers and proponents of guidelines, however, is considerably different. Guidelines are put forth as a means for simplifying application of an uncertain law. They are intended to bring a desired level of certainty, reduce risks of infringement liability, and minimize transaction costs associated with statutory interpretation for common needs. 519 In these regards, this article demonstrates that the guidelines largely have failed. Rather than serve the needs of instructors, librarians, and other individuals, the guidelines have been

517 Retired federal judges or members of Congress, or other persons with solid credentials for independent decisionmaking and without a vested interest in the outcome could serve in this role. An agency, such as the Copyright Office or the Patent and Trademark Office, could facilitate the effort through the selection and compensation of the person. If those agencies were to take a more formal and rigorous approach toward supporting or not supporting the final guidelines, see supra text accompanying notes 209-11, they should in the process bolster their own independence and credibility sufficiently to select such "arbitrators" who will in turn demonstrate competence and independence. Diverse interest groups could also select such independent parties, without any involvement from government agencies, in a manner similar to the common selection of arbitrators to settle numerous legal disagreements. A critical difference, of course, is that arbitrators in common disputes render decisions applicable only to the present parties. Under this proposal, the "arbitrators" would be shaping guidelines that inevitably will become models that many individuals not present will choose or be expected to follow.

518 Kasunic, supra note 415 , at $289-90$ (commenting with respect to the inhibiting force of the guidelines: "This subverts Congress' intent in codifying fair use in section 107. If this course continues, the Guidelines will undermine fair-use analysis and impede the primary function of copyright law: to promote progres [sic] and benefit the public.').

519 See generally Mary R. Barry, Multiple Photocopying by Educators and the Fair Use Doctrine: The Court's Role in Reducing Transaction Costs, 1994 U. ILL. L. REV. 387, 394-95. 
a crutch for judicial rulings and an externally validated structure to ease the task of policymaking - as distinguished from the responsibility of following the law. One can only find failure in guidelines that have missed their constructive goals and served destructive ends. The vast range of parties with an interest in proper application of fair use have been poorly served by existing guidelines, and they would be better served had the guidelines never existed. Better guidelines may be possible in the future, but developers must break from the constructs of the past in order to find a healthier and more productive vision of fair-use standards.

In the meantime, the influence of current guidelines should be resisted. Instead, they are often embraced, principally by individuals who are uncomfortable with the statute's flexibility. Proprietor groups who see guidelines as an opportunity to constrain fair use and to dilute the flexibility that gives the law its vitality have been accomplices. Whatever the intentions of drafters of guidelines, they have been used by diverse parties to generate the appearance of positive law. When publishers use them in litigation and urge their adoption in fair-use decisions, the publishers are seeking to have the guidelines transformed into positive law.

When publishers disseminate the guidelines widely to the community of educators, librarians, and others parties seeking to apply fair use, they are effectively deceiving that community into believing that the guidelines have binding authority. When the user community accepts the guidelines in policy statements, in settlement of litigation, or in other ways that purport to articulate a legal standard, that community is mistakenly treating the guidelines as positive law. When that community actually uses the guidelines and adheres to them, they are reshaping the normative understanding of the law. The guidelines accordingly assume a normative appearance.

These developments in the complex interrelationship between law and guidelines destroy many of the essential objectives of fair use and of the guidelines. The important flexibility of the law is sacrificed. Respect for the law in the community of copyright owners and users is also diminished when the law is interpreted to deviate from statutory language. The effort to craft future informal standards - whether labeled "guidelines" or otherwise-is hindered when the standards are later imposed as if they were binding on all citizens. The fair-use guidelines of the past have created a dangerous illusion; the community 
of owners and users ought to return to the factors of the statute and consider anew the role and structure of guidelines and the process of their development. 520

520 The desire to develop new fair-use guidelines continues. As this article goes to press, Senators Hatch and Leahy have introduced a bill to amend section 110(2) of the Copyright Act, regarding the use of works in distance education, based on a proposal from the United States Copyright Office. See generally, Crews, supra note 176. The bill includes a directive that the Copyright Office "convene a conference of interested parties... to develop guidelines for the use of copyrighted works for digital distance education under the fair use doctrine." S. 487, 107th Cong. $\$ 4$ (b) (2001). The opportunity may soon arise either for repeating the problems of the past or for improving the process and outcome of formulating fair-use guidelines. 